\title{
The Slaving Capital in the Era of Abolition: Liverpool's Silent Rejection of the Slave Trade, 1787-1807
}

Florence Baggett

A thesis submitted to Victoria University of Wellington in fulfilment of the requirements for the degree of Master of Arts in History

Victoria University of Wellington 


\begin{abstract}
In 1787, when the British abolition movement began, the Liverpool slave trade was the largest in the world. Contemporaries throughout Britain, but especially in the port, viewed the slave trade as the primary source of Liverpool's growth and prosperity in the eighteenth century. Liverpudlians, therefore, reacted negatively to the abolition movement, which they viewed as a threat to both the local and national economy. By 1788, the immense popular support generated by the abolition campaign left Liverpool isolated in its defence of the slave trade. Liverpudlians, however, were not unanimous in their support of the slave trade's continuance. In 1787 and 1788, a small group of rational dissenters, known as the Roscoe Circle, anonymously contributed to the abolition campaign from Liverpool. The group's namesake, William Roscoe, went on to be elected Member of Parliament for Liverpool in 1806, and in March 1807 he voted in favour of abolishing the slave trade along with 282 other MPs, against just sixteen, including Liverpool's other MP.

This thesis examines reactions in Liverpool to the British abolition movement between the start of the campaign in 1787 and the passage of the Slave Trade Abolition Act in 1807. It highlights the periods $1787-1788$ and 1796-1807 to challenge the view of Liverpool as a town almost uniformly averse to abolition throughout the twenty year campaign. Chapters One and Two examine the immediate pro- and anti-abolition responses in Liverpool in 1787 and 1788, respectively focusing on the contributions of Liverpool slaving merchants to the anti-abolition campaign and on the abolitionist activities of the Roscoe Circle. Drawing on Liverpool guidebooks and a series of letters in the Liverpool Chronicle, Chapter Three then traces the gradual change in popular feeling towards abolition that occurred in Liverpool in the last decade of the British slave trade's existence. Ultimately, this thesis argues that rapidly dwindling Liverpudlian support for the slave trade from the mid-1790s onward has been under-valued. By 1807 Liverpudlians, wanting to re-affirm cultural ties with the rest of Britain, turned their backs on the slave trade, which had by then become a source of unease and embarrassment.
\end{abstract}




\section{Acknowledgements}

I wholeheartedly thank:

My supervisor, Steve Behrendt - for teaching me the importance of a good topic sentence, for frequently laughing at my syntax, and for seeing me through an Honours and a Masters year.

My parents. Mum - for showing unshakeable confidence in my ability to complete this thesis, and for her tireless proofreading. Dad - for assuring me that a magnifying glass would make eighteenth century handwriting legible. It didn't, but I got to laugh at myself as I pulled out a magnifying glass in the British Library.

The History post-grads: Matt, Daniel, Simon, Talia, Nancy, Laurel, Alexey, Catherine, Alex, Rachel and Grace - for making writing a thesis fun.

Finally, my fiancé Brandon - for encouraging and supporting me through five years of study, and for insisting that adopting a puppy half way through our Masters degrees was a good idea. 


\section{Abbreviations}

Add MS - Additional Manuscripts

BL - British Library

CUR - Currie Papers

HO - Home Office

LRO - Liverpool Record Office

ODNB - Oxford Dictionary of National Biography

ROS - Roscoe Papers 


\section{Table of Contents}

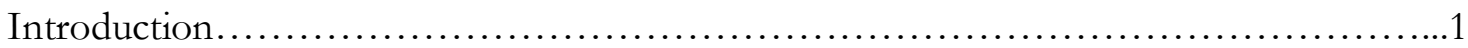

Chapter One: Anti-abolitionism in the Liverpool Context:

A Slave Trading Society Comes Under Attack ...................................... 7

Chapter Two: The Roscoe Circle and Early Liverpool Abolitionism,

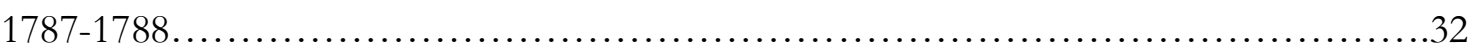

Chapter Three: Rejecting the Slave Trade, 1796-1807.............................56

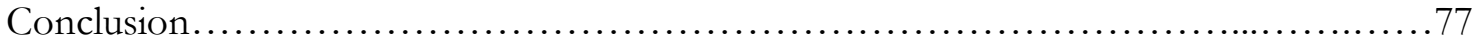

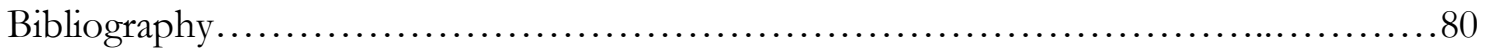




\section{INTRODUCTION}

When Liverpool MP William Roscoe spoke in favour of abolishing the slave trade during the House of Commons debates in February 1807, he emphasized that attitudes in Liverpool had changed since the emergence of the British abolition movement twenty years earlier:

For whatever may be thought of the people of Liverpool, in other parts of the kingdom, I must beg leave to inform this House, that they are by no means unanimous in support of the Trade in question. A great and respectable body of the inhabitants of Liverpool, are as adverse to the Slave Trade as any other persons in these realms; and I should greatly disappoint their expectations, and their wishes, if I were not to vote for the abolition of that Trade. ${ }^{1}$

Since Thomas Clarkson's visit to the town in late 1787, Liverpool had stood out as a staunch supporter of the slave trade. Liverpool slave ships conducted nearly seventy per cent of British slave trading and local contemporaries believed that the town's prosperity depended on the trade's continuance. As Roscoe told the Commons, however, the perception that Liverpudlians were unanimous and unwavering in their support for the slave trade throughout the duration of the abolition campaign was incorrect. Roscoe voted to abolish the British slave trade, as did 282 other MPs, against just sixteen, including Liverpool's other MP, Isaac Gascoyne.

Roscoe's speech is important to historians of Liverpool abolitionism because he contended that a "great and respectable body of the inhabitants of Liverpool" expected his abolitionist vote. But he also did not specify who comprised this "great and respectable body". Indeed, Roscoe's opaque quote is representative of a significant problem that historians face in trying to gauge the extent of Liverpool abolitionism, particularly during the final decade of the trade. Though more detailed sources record Liverpool abolitionism in 1787 and 1788 than in the remaining twenty-year period to 1807 , they too are imbalanced and fragmentary, and do not provide a complete understanding of the breadth of Liverpool abolitionism in these years. Even as Liverpudlians started turning their backs on the slave trade from the mid-1790s, and support for abolition grew significantly, still the identities of these abolitionists and the size of their community are difficult to ascertain.

1 "Abolition of the Slave Trade", Liverpool Chronicle, 4 March 1807. 
This thesis examines the development of abolitionism in Liverpool, from the secretive activities of the Roscoe Circle in 1787-1788, through to the repercussions of Roscoe's vote for abolition in 1807. The aim of this study is not to provide a comprehensive history of Liverpool abolitionism but to address its inherent complexities and merge together two branches of the historiography: one that focuses on the individual contributions of the Roscoe Circle at the beginning of the abolition campaign, and one that argues that Liverpool's cultural renaissance in the decade prior to 1807 reflected growing annoyance that the slave trade still shaped Liverpool's identity. This thesis argues that the Roscoe Circle's contributions to abolition cannot be measured against the standard set by the London Committee as Liverpool abolitionism developed under conditions specific to a large slave trading port, conditions that uniquely placed Liverpool abolitionists within social and economic networks that favoured the slave trade's continuance. It also argues that historians still underestimate the significant shift that occurred in Liverpool's relationship to the slave trade between 1787 and 1807: by late 1806 the majority of Liverpudlians were not necessarily abolitionists, but they had ceased defending the slave trade's continuance, and did not raise substantial objections to Roscoe's vote for abolition in 1807.

In 1787, when the British public mobilised against British participation in the transatlantic slave trade, the inhabitants of Liverpool alone appeared united in support of the trade's continuance. Still expanding, the Liverpool slave trade was the largest in the world. Ships loaded with British merchandise cleared the port of Liverpool for the African coast, where the ships' captains exchanged the goods for slaves. The ships then transported the enslaved Africans to the West Indies for sale to colonial planters. A legitimate branch of British trade, the slave trade generated wealth for Liverpool merchants and provided employment to large numbers of Liverpudlians, facts that led contemporaries to believe that Liverpool's prosperity depended on maintaining the slave trade. The abolition campaign ignited after William Wilberforce, MP for Yorkshire, consented to head the parliamentary attack on the slave trade. In May 1787, London abolitionists founded the London Abolition Committee, and in June they dispatched Clarkson to the provinces to gather witnesses and evidence for Wilberforce to present to the House of Commons.

For a long time Thomas Clarkson's account of the first two years of the abolition campaign directed historians' understanding of Liverpool's role in the abolition movement. A year after Parliament voted to abolish the slave trade, Clarkson, one of the abolition 
movement's leaders, published the first history of the twenty-year campaign. In his twovolume The History of the Rise, Progress, and Accomplishment of the Abolition of the African Slave Trade by the British Parliament, published in 1808, Clarkson over-emphasised the part of Liverpool pro-slavery delegates in fighting the abolitionists in the parliamentary inquiries of 1788, and under-sold the level of Liverpool participation in the early abolition movement in 1787-1788. ${ }^{2}$ Although he included three Liverpudlians (William Roscoe, James Currie and Edward Rushton) on his river-map of influential British and American abolitionists, Clarkson's description of his research journey to Liverpool in September 1787 indicated that while he encountered a few individuals in the port who supported abolition, there was no organised opposition to the slave trade. Clarkson's prioritisation of Liverpool's leadership in the defence of the slave trade - sidelighting Liverpool's participation in the abolition campaign - is reflected in leading works on the history of British abolitionism such as Roger Anstey's The Atlantic Slave Trade and British Abolition and John Oldfield's Popular Politics and British Anti-Slavery. ${ }^{3}$

Historians of Liverpool abolitionism have found that, contrary to Clarkson's information, a form of organised abolitionism did exist in 1787-1788 through the work of the Roscoe Circle. Composed mainly of rational dissenters, including Roscoe, Currie and Rushton, the Roscoe Circle maintained contacts with London abolitionists and figured among the first contributors to the national campaign. Mindful of not upsetting their social standing within Liverpool society, Roscoe Circle members chose not to advertise their support for abolition. They decided against founding a local branch of the London Committee, but nonetheless contributed to the national movement by supplying the London abolitionists with information, and composing abolitionist poems and other works. Moreover, the survival of large collections of papers pertaining to Roscoe Circle members Roscoe, Currie and Quaker merchants William Rathbone III and William Rathbone IV has ensured that these men figure prominently in studies of Liverpool abolitionism. Roscoe and Currie's respective sons each published a biography of their father extensively quoting their correspondence. Later, a Rathbone descendent, Emily Rathbone, published Records of the Rathbone Family in $1913 .{ }^{4}$

\footnotetext{
2 Thomas Clarkson, The History of the Rise, Progress, and Accomplishment of the Abolition of the African Slave Trade by the British Parliament, 2 vols., London 1808.

${ }^{3}$ Roger Anstey, The Atlantic Slave Trade and British Abolition 1760-1810, London, 1975; J. R. Oldfield, Popular Politics and British Anti-Slavery: The Mobilisation of Public Opinion Against the Slave Trade, 1787-1807, London, 1998. 4 The Roscoe and Currie collections are held at the Liverpool Record Office, while Liverpool University's Sydney Jones Library holds the Rathbone Family Papers. Henry Roscoe, The Life of William Roscoe, Vol. I, London, 1833; William Wallace Currie, Memoir of the Life, Writings, and Correspondence of James Currie, M.D. F.R.S. of Liverpool, Vol. I, London, 1831; E. A. Rathbone, Records of the Rathbone Family, Edinburgh, 1913.
} 
Since the early twentieth century, historical studies of Liverpool abolitionism have focused on the abolitionist activities of the Roscoe Circle. In 1928, Jean Trepp produced the first noteworthy study of Liverpool abolitionism. ${ }^{5}$ Drawing heavily on Roscoe and Currie's biographies and on prominent nineteenth and early twentieth century histories of Liverpool, Trepp largely equated the Liverpool abolition "movement" with the individual contributions of Roscoe, Currie and Rushton. ${ }^{6}$ In the 1970s, F. E. Sanderson countered Trepp's claims that the Roscoe Circle's abolitionism in miniature mirrored that of the London Committee's in importance, arguing that the Liverpool abolitionists were minimally effective. Sanderson undertook an extensive examination of different collections of primary sources held at the Liverpool Record Office and published a series of influential articles that examined local politics, abolitionism and anti-abolitionism in the period 1780 to $1807 .^{7}$ Sanderson's work is still the most significant study of the Roscoe Circle, with historians of British abolitionism considering him a definitive source on late 1780s Liverpool abolitionism. $^{8}$

Following Sanderson's example, most studies of Liverpool abolitionism focus on the Roscoe Circle's activities in 1787 and 1788, but in 1988 Seymour Drescher importantly addressed Liverpudlian attitudes towards the slave trade in the lead up to 1807. Drescher's analysis of Liverpool guidebooks, newspapers and local histories published between the 1770s and the 1810s revealed that by the time Parliament voted for abolition in 1807, the slaving faction had lost considerable support in Liverpool. Drescher argued that Liverpudlians' desire to realign culturally with the rest of England caused them to turn

\footnotetext{
5 Jean Trepp, "The Liverpool Movement for the Abolition of the English Slave Trade", Journal of Negro History, Vol.13, No.3, July 1928, pp. 265-85.

${ }^{6}$ Early histories of the town of Liverpool and accounts of the Liverpool slave trade in order: John Walker, $A$ Descriptive Poem on the Town and Trade of Liverpool, Liverpool, 1789; James Wallace, A General and Descriptive History of the Ancient and Present State of the Town of Liverpool, Liverpool, 1795; Thomas Troughton, The History of Liverpool from the Earliest Authenticated Period, Liverpool, 1810; Henry Smithers, Liverpool, Its Commerce, Statistics and Institutions, Liverpool, 1825; Thomas Baines, History of the Commerce and Town of Liverpool, London, 1852; Liverpool and Slavery: An Historical Account of the Liverpool-African Slave Trade by a Genuine "Dicky Sam", 1884; Gomer Williams, History of the Liverpool Privateers and Letters of Marque: With an Account of the Liverpool Slave Trade, Liverpool, 1897; Ramsay Muir, A History of Liverpool, London, 1907; James Touzeau, The Rise and Progress of Liverpool from 1551 to 1835 , Liverpool, 1910.

7 F. E. Sanderson, "The Liverpool Abolitionists", in R. Anstey and P. E. H. Hair (eds.), Liverpool, the African Slave Trade, and Abolition, Chippenham, 1989, pp.196-238; Ibid., "The structure of politics in Liverpool, 17801807", Transactions of the Historic Society of Lancashire and Cheshire, Vol. 127, 1977, pp. 65-89; Ibid., "Liverpool and the Slave Trade: A Guide to Sources", Transactions of the Historic Society of Lancashire and Cheshire, Vol. 124, 1972, pp. 154-76; "The Liverpool Delegates and Sir William Dolben's Bill", Transactions of the Historic Society of Lancashire and Cheshire, Vol.124, 1972, pp. 57-83.

8 Also on the Roscoe Circle, pre-1990s: Ian Sellers, "William Roscoe, The Roscoe Circle and Radical Politics in Liverpool, 1787-1807", Transactions of the Historic Society of Lancashire and Cheshire, Vol. 120, 1968, pp. 45-62; Betty Fladeland, “A Quartet of Liverpudlians: William Rathbone, William Roscoe, James Currie and Edward Rushton," Abolitionists and Working-Class: Problems in the Age of Industrialization, London, 1984.
} 
their backs on the slave trade. In 2002, Jon Stobart likewise linked the development of polite culture in Liverpool from the 1790s to the city's waning support for the slave trade.'

The most recent study of the Liverpool abolitionism places the Roscoe Circle's activities in the context of broader British anti-slavery. Brian Howman's "Abolitionism in Liverpool", published in the 2007 volume Liverpool and Transatlantic Slavery, emerged from his $\mathrm{PhD}$ thesis "An Analysis of Slave Abolitionists in the North West of England", submitted to Warwick University in 2006. In the 2007 publication, Howman examines the connection between the Roscoe Circle's activities in decades before the 1807 Abolition Act and Liverpool's more prominent levels of participation in the emancipation campaigns of the 1820s and 1830s. Howman argues that although historians have underestimated the contributions that the Roscoe Circle made to the national campaign, their level of participation remained, nonetheless, limited. The Roscoe Circle, though, paved the way for organised anti-slavery in 1820s Liverpool. ${ }^{10}$

In recent years, biographies of Roscoe have added to our knowledge of the Roscoe Circle and its abolitionism. Biographies by historian Arline Wilson and local amateur historians Kevin Littlewood and Jonathan Huddleston add detail to the previously concise studies of the Roscoe Circle. Wilson's 2008 work William Roscoe: Commerce and Culture anchors Roscoe's abolitionism in the cultural context of eighteenth century Liverpool and rational dissent. Meanwhile, Littlewood's self-published The Roscoes of Liverpool. Volume 1: Love, Fame and Family Misfortunes, $1753-1816$ provides an extremely detailed account of Roscoe's social life. Notably, Littlewood thoroughly examines Roscoe's correspondence with John Barton, a founding member of the London Committee, and the Roscoe Circle's principle connection to the London abolitionists. ${ }^{11}$

Literary scholars also add to the growing number of studies of Liverpool abolitionist activities. Scholars such as Alan Richardson and Franca Dellarossa analyse the poetical works of Roscoe and Rushton, and place the poems within the development of British anti-slavery poetry. Their interest focused on the poetry rather than the poet's association to the Roscoe Circle, they broaden the scope of Liverpool abolitionism to

9 Seymour Drescher, "The Slaving Capital of the World: Liverpool and National opinion in the Age of Abolition", Slavery and Abolition, 9:2, 1988, pp. 128-43; Jon Stobart, "Culture Versus Commerce: Societies and Spaces for Elites in Eighteenth-Century Liverpool”, Journal of Historical Geography, vol. 28, no. 4, 2002, pp. 471-85.

${ }^{10}$ Brian Howman, 'Abolitionism in Liverpool,' David Richardson, Suzanne Schwarz and Anthony Tibbles (eds.), Liverpool and Transatlantic Slavery, Liverpool, 2007, pp. 277-296; Ibid., "An Analysis of Slave Abolitionists in the North West of England", Ph.D. Thesis, University of Warwick, 2006.

${ }_{11}$ Arline Wilson, William Roscoe: Commerce and Culture, Liverpool, 2008; Kevin Littlewood, The Roscoes of Liverpool. Volume 1: Love, Fame and Family Misfortunes, 1753-1816, self-published e-book, Southport, 2011; Jonathan Huddleston, And Children's Teeth Are Set On Edge: Adam Hodgson and the Razing of Caton Chapel, selfpublished e-book, $2^{\text {nd }}$ ed., 2011, available at http://www.tioli.co.uk, accessed May 2013. 
include figures such as Hugh Mulligan and Eliza Knipe, anti-slavery poets in Liverpool but generally overlooked by historians. Additionally, in examining Currie and Roscoe's collaborative partnership, Scott Krawczyk highlights Currie's "mediating” influence on Roscoe, and places Currie's abolitionism in the context of a northern dissenting network of abolitionists, as opposed to the Quaker abolitionist network centred on the London Committee. $^{12}$

This thesis examines reactions in Liverpool to the movement to abolish the slave trade between 1787 and 1807. Chapter One examines the pro-slave trade response in 1787 and 1788 to the nascent abolition campaign. By showing the level of support that existed for the slave trade in Liverpool in these years, this chapter sets the scene for the abolitionist developments discussed in the subsequent chapters. Chapter Two also addresses the years 1787 and 1788, but focuses on the abolitionist activities of the Roscoe Circle. With a particular emphasis on the roles of Roscoe and Currie, this chapter considers how belonging to Liverpool society affected the Roscoe Circle's opinion of abolition, and how they viewed their roles within the movement. Finally, Chapter Three examines the slow negative reaction to the slave trade that developed within Liverpool society from the mid1790s. It argues that by 1807, active support for the slave trade's continuance in Liverpool was minimal.

12 Alan Richardson,(ed.), Literary Forms: Verse, in Peter J. Kitson and Debbie Lee (eds.), Slavery, Abolition and Emancipation: Writings in the British Romantic Period (8 vols.), Vol. 4, London, 1999; Franca Dellarosa, "Questioning "the Enterprising Spirit of the People": Abolitionist Poetry in Liverpool, 1784-1788", La Questione Romantica, vol.18/2005, 2008, pp. 17-32; Scott Krawczyk, "Mediating Abolition: The Collaborative Consciousness of Liverpool's William Roscoe and James Currie”, Journal for Eighteenth-Century Studies, Vol. 34, No. 2, 2011, pp. 209-27. 


\section{CHAPTER ONE}

\section{ANTI-ABOLITIONISM IN THE LIVERPOOL CONTEXT: A SLAVE TRADING SOCIETY UNDER ATTACK}

\section{$\underline{\text { Introduction }}$}

By 1787, when the British abolition movement began, Liverpool society was uniquely positioned in its relationship to the slave trade. In under a century, Liverpool had become the largest slave trading port in the world, transporting over four times more slaves from Africa to the West Indies than its British rival ports London and Bristol. To contemporaries throughout Britain, and particularly to Liverpool inhabitants, Liverpool owed its current affluence and prosperity to the slave trade. Slave traders viewed the slave trade as a legitimate branch of commerce that contributed to both the British and West Indian economies. Therefore, when abolitionists, such as Thomas Clarkson, started attacking the slave trade in 1787 and 1788, many Liverpudlians felt that their livelihoods were unjustly under threat. By 1788, the strength of the Liverpudlian defence of the slave trade resulted in the view, outside Liverpool, that there were no abolitionists to be found in the town. Examining Liverpool's relationship to the slave trade serves to set Liverpool abolitionism in its very unique context, and sets the scene for the next chapters' examination of its development over the course of the campaign.

This chapter examines the pro-slave trading response to the abolition movement in 1787 and 1788. It starts by providing an overview of the Liverpool slave trade's rapid rise in the eighteenth century, and the influence it then held over Liverpool society. It argues that a dearth of outward displays of antislavery sentiment by locals prior to 1787 demonstrated widespread apathy to the plight of African slaves, which cemented slaving merchants' belief in the moral acceptability of their trade. Clarkson's fact finding mission to Liverpool in late 1787 gave the slave traders their first cause for alarm, although they let their guard down again after his departure. Finally, this chapter examines Liverpool's antiabolition campaign in 1788, both in Parliament and in Liverpool. 
Liverpool: a slaving port

From the mid-eighteenth century to the abolition of the British slave trade in 1807, Liverpool ranked as the largest slave trading port in the world. Liverpool merchants officially entered the slave trade in 1698 when the British Parliament ended the monopoly of the London-based Royal African Company. Despite evidence suggesting that Liverpool merchants illegally financed a small number of voyages in the 1690s, the port's trade did not rapidly take off, with only seven slave ships recorded leaving the port in the first decade of the eighteenth century. ${ }^{13}$ Liverpool's participation in the trade did not increase significantly until the late 1710 s, when Liverpool ships carried over 500 slaves to Barbados annually between 1715 and $1718 .{ }^{14}$ By the 1720s, Liverpool had become England's third largest slave trading port, behind Bristol and London; in the 1730s Liverpool ships transported over 44,000 slaves to the West Indies, more than double the total of its slave transports for the previous three decades; and in 1744, Liverpool overtook Bristol as the leading slave trading port. ${ }^{15}$ In the 1750 s, an estimated 478 Liverpool slaving voyages carried more than 100,000 imprisoned Africans to the West Indies. In the 1790s, when the port's trade reached its height, at least 865 voyages transported nearly 269,000 slaves. In total, between 1698 and 1808 Liverpool ships carried more than 1,335,000 African slaves to the West Indies on 4709 documented voyages, half of which occurred in the last three decades of the trade's existence. ${ }^{16}$

\footnotetext{
${ }^{13}$ The slave trade database records two slave voyages from Liverpool to Montserrat in 1696, Slave Trade Database, www.slavevoyages.org.

${ }^{14}$ James A. Rawley, with Stephen D. Behrendt, The Transatlantic Slave Trade: A History, Revised Edition, Lincoln, 2005, p. 167.

${ }^{15}$ Dresser, Madge, Slavery Obscured: The Social History of the Slave Trade in an English Provincial Port, London, 2001, p. 28.

${ }^{16}$ Slave Trade Database.
} 


\section{Liverpool's slave trading growth.}

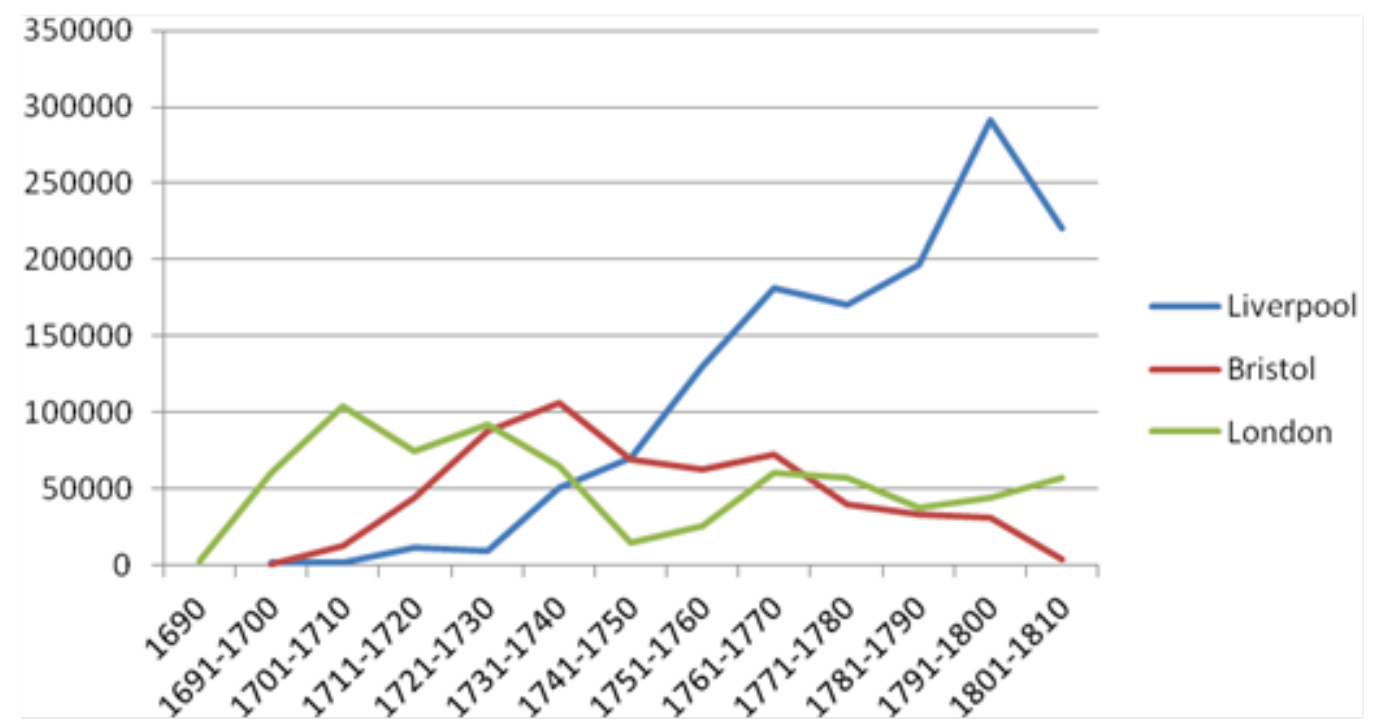

Source: www.slavevoyages.org

Kenneth Morgan's recent study of the Liverpool slave trade suggests that the port's geographic location helps to explain its rapid ascendency in the slave trade. Liverpool, he argues, gained three principal advantages from its location on the Irish Sea, backed by an industrialised hinterland. First, the Irish Sea, deemed dangerous by foreign mariners, protected Liverpool vessels from enemy privateers during wartime. French and Spanish ships, lingering at the mouth of the Channel, disrupted the overseas trade of London, Bristol, and other s outhern ports, but Liverpool ships evaded the enemy by sailing north around Ireland. ${ }^{17}$ Second, until 1765 Liverpool ships could purchase East India goods, valued by African merchants, tax-free from the Isle of Man on their outward journey to the African coast. ${ }^{18}$ Third, Liverpool's close connection to its industrialised hinterland provided merchants with easy access to low cost goods for shipping. Textiles comprised the most important export-good to Africa, both in value and quantity, and by the 1750 s Lancashire cottons and linens provided Liverpool slaving merchants with cheaper quality alternatives to East Indian textiles. By the end of the century, slavers almost exclusively exported British-made goods, predominantly textiles. ${ }^{19}$

Early investment in the port's infrastructure and rapid population growth also help explain Liverpool's success in developing its slave trade. Towards the end of the

\footnotetext{
${ }^{17}$ Kenneth Morgan, “Liverpool's Dominance in the British Slave Trade, 1740-1807”, in David Richardson, Suzanne Schwarz \& Anthony Tibbles (eds.), Liverpool and Transatlantic Slavery, Liverpool, 2007, p. 20.

18 Ibid., p. 21.

19 Ibid., pp. 22-3.
} 
seventeenth century, Liverpool looked to strengthen its presence in Atlantic trade. In order to promote the expansion of its maritime trade, the town invested in the port's facilities. By 1715, Liverpool possessed the world's first commercial wet dock, facilitating the rapid turnaround of larger ships entering the port. ${ }^{20}$ Within a century, the port of Liverpool consisted of six wet docks, three dry docks and five repair docks. ${ }^{21}$ In addition, the town developed transport links with its hinterland, securing easy procurement of raw materials and manufactures for export, and providing the port with a ready market for its imports. ${ }^{22}$ By the mid-eighteenth century, Liverpool had become the third largest British importer of Chesapeake tobacco and West Indian sugar, and its flourishing transatlantic trade provided a basis on which to expand its slave trade. ${ }^{23}$ Liverpool and Lancashire's demographic growth in the eighteenth century underpinned the town's transformation into a port of international importance, providing the port with a large workforce and powering the region's industrial growth. Liverpool counted an estimated 5,145 inhabitants in 1700, 18,400 in 1750 , and 77,653 in $1801 .^{24}$

Liverpool slaving merchants developed distinct business methods that ensured their continued dominance of the slave trade. For example, Liverpool merchants reduced turnover times by placing agents in the colonies to accumulate export cargoes before slave ships' arrivals, and to continue selling slaves after the ships' departures. ${ }^{25}$ By trading in both tobacco and sugar, Liverpool merchants adapted to fluctuating markets, unlike their London and Bristol counterparts who handled only one commodity or the other. ${ }^{26}$ In Britain, Liverpool merchants often obtained longer terms of credit from Manchester tradesmen. ${ }^{27}$ Liverpool merchants were also typically more enterprising in tapping into new slave supply regions in Africa, and in entering new and foreign markets in the West Indies. ${ }^{28}$ Steve Behrendt's study of Liverpool slave ship crews found that whereas Bristol and London merchants sent their ships to African regions where the British maintained forts and agents, Liverpool merchants hired skilled officers to trade directly with African merchants. Captains who gained expert local knowledge of African slave markets, and who

\footnotetext{
20 Jane Longmore, “Civic Liverpool: 1680-1800”, in John Belchem (ed.), Liverpool 800: Culture, Character and History, Liverpool, 2006, pp. 121-23.

21 The London Encyclopaedia, or Universal Dictionary of Science, Art, Literature, and Practical Mechanics, Comprising a Popular View of the Present State of Knowledge. Illustrated by Numerous Engravings, a General Atlas, and Appropriate Diagrams, Volume 7, London, 1829, p. 375.

22 Longmore, "Civic Liverpool”, p. 116.

23 Morgan, “Liverpool’s Dominance”, p. 17; Longmore, “Civic Liverpool”, p. 115.

${ }^{24}$ Longmore, "Civic Liverpool”, p. 169.

25 Gail Cameron and Stan Crook, Liverpool: Capital of the Slave Trade, Liverpool, 1992, p. 7.

${ }^{26}$ Rawley, Transatlantic, p. 167.

${ }^{27}$ Morgan, “Liverpool's Dominance”, p. 32.

28 Ibid., pp. 26-7, 29.
} 
maintained relationships with African merchants, demanded higher wages and bonuses than those who relied on European agents to conduct slave purchases. ${ }^{29}$

It is difficult to estimate the slave trade's importance to the Liverpool economy. For instance, very few Liverpool slaving merchants engaged exclusively in the slave trade, and existing financial records do not always elucidate merchants' different sources of revenue. ${ }^{30}$ Besides, not all slave trade voyages were financed solely by slaving merchants as general merchants often held shares in slaving ventures, and research has revealed that nearly all affluent Liverpool merchants invested in at least one slaving voyage. ${ }^{31}$ Moreover, although records show that, in the last quarter of the eighteenth century, slave ships only accounted for 10 to 11 per cent of the port's total tonnage, they do not disclose the comparative values of exported cargoes. ${ }^{32}$ Nonetheless, a significant decrease in the port's slave trading activity in 1777-1780, caused by the American Revolutionary Wars, suggests that the Liverpool economy did not rely as much on the trade as contemporaries believed. As Thomas Clarkson discovered in 1787, dock duties for 1779 were higher than those for 1772 despite the number of slave voyages falling from 100 to eleven. ${ }^{33}$ The drop was important enough for Clarkson to argue that Liverpool had survived a "practical experiment" in abolition. ${ }^{34}$

Whatever the comparative economic importance of the slave trade, it provided incomes to a large number of Liverpudlians besides the ship owners and merchantinvestors. The largest group to gain employment directly from the trade were Liverpool seamen. In the 1770 s, the slave trade may have employed up to a quarter of Liverpool mariners annually. In that decade, slave ships required on average thirty crewmembers, including the captain and mates, a surgeon and a carpenter. As Madge Dresser highlights in her study of the Bristol slave trade, many other professions profited from the slave trade. Dockworkers, such as carters and porters, helped load and unload slaving vessels. Local shipbuilders, sailmakers, and ropemakers prepared vessels for the trade. Local retailers

\footnotetext{
${ }^{29}$ Stephen D Behrendt, "Human Capital in the British Slave Trade", in David Richardson, Suzanne Schwarz and Anthony Tibbles, eds., Liverpool and Transatlantic Slavery, Liverpool, 2007, pp. 67-70.

30 Pope addresses the difficulty in establishing the source of slavers' wealth in Pope, David, "The Wealth and Social Aspirations of Liverpool's Slave Merchants of the Second Half of the Eighteenth Century", in D. Richardson, S. Schwarz and A. Tibbles, Liverpool and Transatlantic Slavery, Liverpool, 2007, pp.164-226.

31 Rawley, Transatlantic, p. 180.

32 Rawley, Transatlantic, p. 171; Jane Longmore, "Cemented by the Blood of a Negro'? The Impact of the Slave Trade on Eighteenth Century Liverpool", in David Richardson, Suzanne Schwarz and Anthony Tibbles (eds.), Liverpool and Transatlantic Slavery, Liverpool, 2007, p. 237.

33 Clarkson, History, Vol. I, pp. 373-4. The slave trade database records 84 voyages departing in 1772, 98 in 1774, 15 in 1779, and 14 in 1780.

34 Keith P. Hertzog, "Naval Operations in West Africa and the Disruption of the Slave Trade during the American Revolution", American Neptune, 55, 1, 1995, p. 42.
} 
provided provisions and equipment. When ships returned, women were commissioned to wash captains' laundry, and men to clean the vessels. More indirectly, slaving merchants hired clerks in their counting houses and warehouses holding Africa-bound goods required labourers. ${ }^{35}$

Jane Longmore argues that the slave trade promoted the growth of local industry. On a large scale, ship-building and copper works appear to have been most boosted by the slave trade. Liverpool ship-builders constructed nearly half of all vessels used in the Liverpool slave trade between 1701 and 1800, and in addition to supplying slave ships with brass and battery wares, the Liverpool copper works sheathed the hulls of slave ships in copper to protect the wood from parasites present in the warm African waters. ${ }^{36}$ Longmore also argues that the slave trade encouraged the development of local manufactures for export, which ceased when the trade ended. She believes that Liverpool artisans produced goods such as guns, copperware, beer, clay pipes and earthenware for the African market. ${ }^{37}$ She estimates that, by 1790 , about one in eight, or 10,000, Liverpudlians derived their income from the trade. ${ }^{38}$

In addition to driving the port's economy, the slave trade's importance shaped Liverpool politics. The Liverpool Corporation was one of the wealthiest in England, making its governing body, the Common Council, the town's most important economic power. ${ }^{39}$ The Council comprised the mayor and up to forty-one council members. Over the course of the eighteenth century, members of Liverpool's established mercantile families who held a financial stake in the slave trade gained control of the Council. Membership to the Council was closed, and members held their position for life. As existing members alone had the power to elect new members, or to keep seats vacant, they maintained a Council that consistently favoured the Guinea trade. In 1787, thirty-seven of the forty-one members of the Common Council were connected to the slave trade; and thirty-four out of thirty-eight in 1797. Furthermore, every mayor of Liverpool's between 1787 and 1807 was directly involved in the slave trade, either as ship owner or investor, as were each of the city's Members of Parliament until William Roscoe's election in $1806 .{ }^{40}$

Local politicians worked to develop, and later to defend, Liverpool's slave trade. The Common Council prioritised the promotion of Liverpool commerce in general, and as

\footnotetext{
35 Dresser, Slavery Obscured, pp. 29-31.

${ }^{36}$ Longmore, "Cemented", pp. 240, 242; Dresser argues that the slave trade likewise boosted Bristol's copper works industry, Slavery Obscured, p. 31.

${ }^{37}$ Longmore, "Cemented", pp. 237-38.

38 Ibid., pp. 243.

39 Stobart, "Culture", p. 479.

40 Sanderson, "Structure of Politics", pp. 65-6; Rawley, Transatlantic, p. 172.
} 
such was responsible for the improvements made to the docks and transport infrastructure. Over the course of the eighteenth century, it devoted considerable time and resources to advancing and protecting the town's slave trade specifically. The Council petitioned Parliament against the Royal African Company regaining former privileges, against the activities of the South Sea Company, and in favour of naval protection for slaving vessels. It also petitioned the Jamaica Assembly against a proposed duty on slaves. In the 1740s, Liverpool MPs pressed Parliament for a free and open trade. ${ }^{41}$ Liverpool politicians' efforts on behalf of the slave trade were most evident once the abolition movement developed in 1787. By early 1788 the Council, in conjunction with the African Merchants of Liverpool, not only produced the country's only significant counter-abolition petition but also appointed a delegation responsible for procuring "expert" witnesses to testify against abolition before the Privy Council. ${ }^{42}$

By the 1780s, then, the slave trade had become intrinsic to Liverpool's economy, society and politics. Outsiders had long deplored the port's ascendency in the trade, as demonstrated by the well-known reaction of a drunken actor performing at the Theatre Royal in 1772. Upon being booed during his performance, the famous George F. Cook told his audience that he had "not come to be insulted by a pack of men, every brick in whose detestable town was cemented by the blood of a negro". ${ }^{43}$ But to Liverpudlians, the slave trade formed an important component to the town's commercial success, from which the town derived its identity. ${ }^{44}$ The wealth generated by the slave trade legitimised it to the townsfolk. Not only did the trade create employment, but nearly all town leaders participated in the trade in some way. The slave trade gained a level of social acceptability in Liverpool, impossible outside a large slave trading port where the direct influence and benefits of the trade could not be felt. This preponderance of confidence in the slave trade's legitimacy is demonstrated by the lack of anti-slavery ideology exhibited prior to 1787.

\footnotetext{
${ }^{41}$ Cameron and Crook, Liverpool, pp. 8-9.

42 Drescher, Capitalism and Antislavery, in Stephen Farrell, Melanie Unwin and James Walvin (eds.), The British Slave Trade: Abolition, Parliament and People, Edinburgh, 2007, p. 49; Anstey, Slave Trade, p. $268 n 53$.

${ }^{43}$ Quoted in Drescher, "Slaving Capital", p. 131.

${ }^{44}$ Longmore argues that Liverpool had little historic heritage around which to form an identity, unlike older ports such as Bristol or Hull, and therefore drew on the port's recent commercial success as a source of an "alternative identity for the port, a dynamic, confident and contemporary image that required no justification or reference to past glory". Longmore, "Civic Liverpool”, p. 152.
} 


\section{Liverpool anti-slavery activity or lack thereof}

In December 1787, Liverpool abolitionist James Currie explained to Yorkshire MP William Wilberforce that the longevity and legality of the slave trade had resulted in the view that it was a legitimate branch of commerce and was beyond reproach. ${ }^{45}$ The conspicuous lack of Liverpudlian denunciations of the slave trade, prior to 1787, supports Currie's statement. Indeed, very few records of anti-slave trade activity in Liverpool exist before the 1780s. Newspaper articles further highlight pervasive Liverpool indifference to the African slaves' plight.

The earliest record of an attempt by a Liverpudlian to discourage the slave trade originated within the Quaker community. As early as the 1670s, Quaker founder George Fox had denounced slavery, but it took until 1761 for British Friends to declare member participation in the slave trade punishable by disownment. ${ }^{46}$ By the late 1760s, British Quaker leaders advocated pressing British lawmakers and the non-Quaker community for abolition. In 1770, they asked Liverpool Friend and timber merchant William Rathbone III to circulate several dozen copies of Anthony Benezet's abolitionist tract $A$ Caution and a Warning to Great Britain and her Colonies. Rathbone, a highly respected Liverpool merchant, later figured among the Roscoe Circle with his son William Rathbone IV. ${ }^{47}$ In late 1786, he also helped Clarkson advance his research on sailor mortality by supplying the young abolitionist with copies of Liverpool muster rolls, and became Clarkson's primary contact in Liverpool. ${ }^{48}$

Importantly, Liverpool Quakers demonstrated less aversion to slavery than their counterparts in Bristol. In 1761, Bristol Quakers responded to the injunction against participation in the slave trade by creating a deputation to discover any Bristol Friends engaged in the trade. ${ }^{49}$ No such steps appear to have been taken in Liverpool, where many Quakers may have been indirectly involved in the slave trade despite repeated demands from the Society of Friends that members "keep their hands clean of giving

45 W. Currie, Memoir, pp. 116-17.

46 Since the 1720s British Quakers had ineffectively attempted purging their religious organisation of the sin of slave trading. As Brown explains, their endeavours before 1768 are better described as separatism than abolitionism, as they only sought to end Quaker involvement in the slave trade, and never the trade itself. In 1767, Philadelphia Quaker and leading American abolitionist Anthony Benezet notably urged his British brethren to pursue Abolition, penning his first abolitionist tract targeting a British audience: $A$ Caution and a Warning to Great Britain and her Colonies, Philadelphia, 1767. See Anstey, Slave Trade, pp. 219-21; Christopher Leslie Brown, Moral Capital: Foundations of British Abolitionism, Chapel Hill, 2006, pp. 91, 400-05; James Walvin, The Quakers: Money and Morals, London, 1998, p. 127.

${ }^{47}$ William Rathbone III, b.1726 - d.1789, William Rathbone IV, b.1757-d.1809.

48 A\&P, 1789, XXVI. Report of the Privy Council Committee on the Slave Trade, Part II, p. 144.

${ }^{49}$ Dresser, Slavery Obscured, p. 131. 
encouragement, in any shape, to the slave trade". ${ }^{50}$ Rathbone III, whom Clarkson mistakenly praised for shunning involvement in the slave trade, in fact supplied wood for slaving vessels until 1783. Sanderson argues that his timber business, before this date, could not have survived a slave trade boycott. Nonetheless, Rathbone IV, the most wellknown Liverpool Quaker abolitionist, apparently showed no remorse in later shipping slave-grown cotton, as he famously boasted of being the first importer of American cotton into Liverpool in $1784 .^{51}$

Insufficient research exists on Liverpool Dissenters, and the Quaker community in particular, to explain the Liverpool Friends' apathy towards member involvement in the slave trade. Perhaps a smaller community size, distance from the organisation's leaders in London and reliance on the port's slave trade-centered economy could be factors in local Quakers' reluctance to follow Bristol's lead. Gore's Liverpool Directory for 1781 lists seven Church of England churches, 5 Dissenting chapels and 2 Catholic churches. ${ }^{52}$ Gore did not include the Quaker Meeting house in Hackins Hey, established in 1710; a new Meeting House built by 1792 on Hunter Street reflected larger membership and increased wealth of local Quakers. ${ }^{53}$ Bristol had two Meeting Houses by the 1770 s, and the Quaker community was known for its wealth. Towards the end of the century Liverpool's Dissenting Churches rivalled Anglican Churches in number, but records do not indicate whether Dissenting congregations matched Anglican ones for size. Meanwhile, Bristol had the largest and most diverse dissenting community outside London. Bristol Dissenters composed twenty per cent of the electorate, and commanded even more votes by their influence. Liverpool records do not reveal the number of dissenting freeman voters, but Bradley estimates that it was well below the sixteen per cent it had been at the start of the century. ${ }^{54}$

Poetry provides the only other known examples of Liverpudlian anti-slavery sentiment prior to 1787. Scholars identify William Roscoe's Mount Pleasant as the earliest example of Liverpool poetry condemning slavery. ${ }^{55}$ Written in 1771 by an eighteen-yearold Roscoe, Mount Pleasant was published in 1777 by the Dissenting Warrington Academy, just outside Liverpool. The poem, otherwise a celebration of Liverpool, treated the slave trade and slavery as a single issue, the consequence of unchecked commercial greed that had tarnished "with blackest infamy the age". The poet did not single Liverpudlians out for

\footnotetext{
50 Anstey, Slave Trade, p. $221 n 51$.

51 Clarkson, History, Vol. I, pp. 413-14; Sanderson, “Liverpool Abolitionists”, pp. 199-200; Anstey, Slave Trade, p. $221 n 51$; A. Wilson, Roscoe, p. 41.

52 Gore's Liverpool Directory, Liverpool, 1781.

${ }^{53}$ www.liverpoolquakers.org.uk/about/liverpool-and-the-quakers, accessed 4 December 2012.

54 James E. Bradley, Religion, Revolution and English Radicalism, Cambridge, 1990, pp. 199, 206-7, 275.

55 William Roscoe, Mount Pleasant, Warrington, 1777.
} 
blame, but held all Britons accountable. ${ }^{56}$ In 1782, another historically recognised Liverpool abolitionist, Edward Rushton, published his first anti-slavery poem, The Dismembered Empire. ${ }^{57}$ Roscoe and Rushton continued to use poetry to voice their political views throughout their lives. And, as Roscoe Circle members, they favoured poetry as a platform for their abolitionism, particularly between 1787 and 1788 .

The existence of a third Liverpool poet highlights the gaps that exist in historians' current knowledge of Liverpool abolitionism. Literary scholars attribute anti-slavery poems published in Gentleman's Magazine in 1777 and 1784 to a Liverpool poet named Hugh Mulligan. ${ }^{58}$ Little is known about Mulligan, except that he was of Irish birth but lived and worked in Liverpool. Wilson describes him as a painter and engraver who gave classes to a young Roscoe. ${ }^{59}$ By 1800 Mulligan had established himself as a Liverpool "Engraver and Bookseller". ${ }^{60}$ Rushton's poem, 'On the Death of Hugh Mulligan', published in 1806, places his death before then. ${ }^{61}$ Although scholars of abolitionist poetry place Mulligan on equal standing with Roscoe, Rushton, Currie and Shepherd, he remains noticeably absent from the histories of Liverpool abolitionism, even though the Liverpool abolitionists themselves recognised his contributions. Writing to Roscoe after the release of Clarkson's History in 1808, Rathbone IV lamented that the historian had not included "poor" Mulligan on his river map of influential abolitionists. ${ }^{62}$ In 1788, in fact, Mulligan had published Poems Chiefly on Slavery and Oppression.

The near complete absence of displays of abolitionist sentiment in Liverpool was perhaps symptomatic of widespread Liverpudlian indifference to the slave trade. In examining a wide-ranging selection of British newspapers, the eminent slave trade historian Seymour Drescher traced public reactions across England to events that defined the abolition campaign. He found that while the Liverpool newspapers reported in some detail on the Somerset case in 1771-1772 and the Quaker petition of 1783, Liverpudlians did not respond in print. In the first instance, Lord Mansfield's ruling in the Somerset case,

56 Roscoe, Mount Pleasant, pp. 10-8; A. Wilson, Roscoe, pp.36-8; Roscoe, Life, pp. 30-3; Fladeland, "Quartet", pp. 20-1.

57 Michael Royden, 'Rushton, Edward (1756-1814)', Oxford Dictionary of National Biography, Oxford University Press, 2004 [http://www.oxforddnb.com/view/article/24286, accessed 22 March 2013]; Henry Smithers, Liverpool, pp. 324, 398; Sanderson, "Liverpool Abolitionists", p. 205.

58 Alan Richardson, 'Introduction', in Peter J. Kitson and Debbie Lee (eds.), Slavery, Abolition and Emancipation: Writings in the British Romantic Period (8 vols.), Alan Richardson (ed.), Literary Forms: Verse, (Vol. 4), London, 1999, p. xï; Dellarosa, 'Questioning', pp. 20-1.

59 A. Wilson, Roscoe, p. 33. Wilson does not mention that Mulligan published antislavery poems.

${ }^{60}$ Gore's Directory, 1800, p. 103.

${ }^{61}$ Rushton, Poems, London, 1806.

${ }^{62}$ Rathbone to Roscoe, 24 April 1808, LRO 920/ROS/3066. Kevin Littlewood's biography of the Roscoes delves into the relationship between Mulligan and Roscoe, and recognises Mulligan's poetical contributions to abolition. Littlewood, The Roscoes, pp. 16, 81, 106. 
effectively ended slavery in England. In the second, MPs reacted encouragingly to the first abolitionist petition presented to Parliament in June 1783, much to the surprise of the Quaker petitioners. ${ }^{63}$ Whereas Londoners reacted to both events by publishing tracts or writing to the newspapers, Liverpudlians remained silent. Drescher attributes Liverpudlian lack of interest in both events to their confidence in the legality and security of the slave trade. ${ }^{64}$

The case of the slave-ship Zong demonstrates that Liverpudlians over-looked documented acts of barbarity that occurred in the slave trade. As is well-known, in November 1781, the captain of the Zong ordered 132 diseased Africans thrown overboard on pretence of water shortage, allowing the vessel's Liverpool investors to claim insurance on the 'lost' cargo in March 1783. Historians, who disagree as to the extent of publicity garnered by the trial, have not found any record of the event or the trial in Liverpool newspapers. ${ }^{65}$ While the trial was conducted in London, it is unlikely that Liverpudlians remained unaware of the incident, considering the size of the syndicate of Liverpool merchants, and the local crew ordered to testify before the court. More than just ignoring the murder of Africans for profit, the townsfolk failed to demand any accountability from the responsible merchants, or to condemn them for their role in permitting such acts of atrocity in the trade. In 1784, Liverpudlians elected John Gregson, one of the Zong's investors, mayor of Liverpool. ${ }^{66}$

When Clarkson reached Liverpool in September 1787 he entered a town that not only owed much of its current prosperity to the slave trade, but that also had next to no history of anti-slavery activity. Against this backdrop, Clarkson's sudden loud and unmitigated condemnation of the slave trade caught Liverpool merchants off-guard. As Currie explained to Wilberforce, Liverpool's slaving merchants "began to discover that hostile notions were entertained of their conduct and sentiments, which they were not

${ }^{63}$ For an in-depth analysis of the intricacies of the Somerset case see Drescher, Capitalism and Antislavery, $2^{\text {nd }}$ ed., New York, 1987, pp. 36-43. For more on the 1783 Quaker petition see Brown, Moral Capital, pp. $422-24$. ${ }^{64}$ Drescher, "Slavery and Abolition", pp. 132-33.

${ }^{65}$ In his recent work on the Zong, Walvin argues that the case laid the foundation for the abolition movement by introducing the British public to the horrors of the slave trade. Drescher, however, found only three contemporary references to the Zong Affair in British newspapers, prompting him to argue that the case only gained notoriety when abolitionists referenced it after 1787. Walvin does not produce any additional contemporary references to the Zong Affair to prove Drescher wrong. See James Walvin, The Zong: A Massacre, the Law and the End of Slavery, New Haven, 2011; Drescher, Capitalism and Antislavery, pp. 60, 204n30; Drescher, 'The Shocking Birth of British Abolitionism', Slavery and Abolition, Vol. 33, No. 4, Dec. 2012, pp. 575-76. Swaminathan agrees with Drescher in her comparative study of the Zong and Kimber trials: Srividhya Swaminathan, "Reporting Atrocities: A Comparison of the Zong and the Trial of Captain John Kimber", Slavery and Abolition, Vol. 31, No. 4, Dec. 2010, pp. 483-99.

66 The syndicate was comprised of: William, John and James Gregson, Edward Wilson, James Aspinall and George Case, all feature in David Pope's list of Liverpool's leading slaving merchants. Pope, "Wealth", pp. 194-207. 
conscious that they deserved" ${ }^{67}$ Clarkson's investigations in the port in September and October 1787 gave the town's slaving merchants their first serious cause for alarm in nearly a century of slave trading.

\section{Thomas Clarkson}

On 12 June 1787 the London Abolition Committee "resolved that Thomas Clarkson be requested to proceed as soon as he conveniently can, to Bristol, Liverpool, and such other Places as he may think necessary, in Order that he may collect Information on the subject of the Slave Trade". ${ }^{68}$ By visiting the leading slave trading ports in the early stages of the abolition campaign, Clarkson hoped to gather more pertinent information than would be possible if he waited. He foresaw that once the campaign gained national importance, and the slave trade issue became more hotly contested, eyewitnesses would feel the need to conceal facts. ${ }^{69}$

When the London Abolition Committee formed in May 1787, it strategically decided to target the slave trade. British anti-slavery had historically encompassed condemnation of the slave trade and West Indian slavery but the Committee decided to focus on the slave trade for practical and political reasons. Attacking slavery entailed making claims on planters' property, which would have been legally difficult, and the Committee doubted Parliament's ability to interfere in the internal administration of the colonies. The question of emancipation, moreover, was highly charged, even dividing the Committee; some members did not support colonial emancipation at all. ${ }^{70}$ Parliament could, however, legislate on matters of British trade, and would be better placed to enforce slave trade abolition than slave emancipation. ${ }^{71}$ As a letter from Clarkson to the French abolitionist Mirabeau shows, the London Committee believed that abolition would naturally lead to emancipation: ${ }^{72}$

My opinion, like that of all those who have looked closely at the subject, is that one ought to demand only the abolition of the slave trade. It is the source of all evils, and if the axe is applied to it, slavery in the islands will fall after it, and will fall

\footnotetext{
${ }^{67}$ W. Currie, Life, p. 122.

${ }^{68}$ London Committee Minutes, 12 June 1787, BL Add MS 21254.

${ }^{69}$ Clarkson, History, Vol. I, pp. 289-90.

${ }^{70}$ Judith Jennings, The Business of Abolishing the Slave Trade, 1783-1807, London, 1997, p. 36.

${ }_{71}$ Clarkson, History, Vol. I, pp. 284-7; Jennings, Business, p. 36.

72 Ibid., History, Vol. I, pp.284-5.
} 
advantageously for the planters and for the slaves without any need to touch it... This reasoning compels us to put aside any idea of emancipation. ${ }^{73}$

Thus, in September 1787 Clarkson visited Bristol and Liverpool to uncover evidence for Wilberforce to present against the slave trade in the House of Commons.

A young Anglican abolitionist, Clarkson proved a key driving force behind the nascent campaign. Two-thirds of the London Committee members were Quakers, and he therefore used the Quaker network to make contacts in the town's he visited. ${ }^{74}$ In Bristol, in particular, he recounted being welcomed into the local Quaker community; interestingly he did not describe a Quaker community in Liverpool. ${ }^{75}$ On his way to Liverpool, he obtained pledges to petition Parliament from all the towns he visited, including Bristol. ${ }^{76}$ He succeeded also in forming several local abolition committees and received assurances from provincial newspaper editors to publish abolitionist articles. ${ }^{77}$ Clarkson's fact findingmission, John Oldfield has argued, made him both the public face of the abolition campaign and the leading expert on the slave trade. ${ }^{78}$ Clarkson detailed his 1787 travels in the first volume of his History of the abolition campaign, published in 1808, a year after Parliament voted to end the British slave trade.

A well-known story from Clarkson's 1787 visit to Liverpool illustrates his view that the slave trade had a greater hold on Liverpool than Bristol. Clarkson had found that in Bristol, although nobody thought of abolition, a majority of the townsfolk he met "seemed to execrate" the trade. ${ }^{79}$ In Liverpool, however, people appeared more hardened to the trade, and discussed it more frequently and with less feeling. One day, when walking through town, Clarkson noticed a set of iron restraining implements in a shop window. He learnt from the shopkeeper that, on board, slaving captains kept slaves fastened to each other by handcuffs and leg shackles. Additionally, ships carried instruments of torture called thumbscrews, which captains used at their discretion to punish slaves for

\footnotetext{
73 Letter from Clarkson to Mirabeau, 14 November 1789, in Marcel Dorigny "Mirabeau and the Société des Amis des Noirs: Which Way to Abolish Slavery?," Marcel Dorigny (ed.), The Abolitions of Slavery, Paris, 2003, p.127.

74 The 1787 London Committee founders were: the Quakers George Harrison, Joseph Woods, Samuel Hoare, John Lloyd, William Dillwyn, Richard Phillips, James Phillips, John Barton, Joseph Hooper; and the Anglicans Thomas Clarkson, Granville Sharp, and Philip Sansom. J. R. Oldfield, "The London Committee and Mobilization of Public Opinion against the Slave Trade", Historical Journal, Vol. 35, No. 2, June 1992, p. 332.

75 Clarkson's relationship to Liverpool Quakers will be discussed in Chapter Two, as will his research in Liverpool into Guinea-sailor treatment and mortality.

${ }^{76}$ London Committee Minutes, 16 October 1787, BL Add MS 21254. The towns were Bristol, Bridgewater, Monmouth, Bath, Gloucester, Worcester, and Chester.

${ }_{77}^{77}$ For Clarkson's account of his journey before reaching Liverpool, see his History, pp. 293-370.

78 Oldfield, Popular Politics, pp. 74-5.

${ }^{79}$ Clarkson, History, Vol. I, p. 296.
} 
"obstinacy" and other offences. Another device, known as a speculum oris, would be inserted down a slave's throat to force them to swallow food. Clarkson was shocked to find these tools so visible and readily available. ${ }^{80}$

Clarkson used his discovery of the iron implements to contradict the fallacy that slaves voluntarily boarded European slaving vessels. Slaving merchants propagated the story that African slaves, if left in Africa, would be put to death. Slaves, therefore, welcomed their purchase by Europeans, and were happier on the plantations than in their native countries. However, the ubiquitous use of these instruments indicated that merchants and captains not only feared that without them slaves would try to escape or harm the crew, but also that slaves would often rather starve themselves to death than be taken across the ocean. Clarkson purchased a set of manacles and leg shackles, as well as a thumbscrew and a speculum oris, to show to people and give them an appreciable understanding of slave treatment on the Middle Passage. He had engravings made of the instruments and published them in an illustrated pamphlet with a detailed description of their functions. He also included the images in his 1788 Impolicy essay and his History. In 1788, he presented the instruments to the Privy Council when it interviewed him as part of its investigations into the slave trade. ${ }^{81}$

Clarkson did not conceal his purpose for being in Liverpool. "I was never ashamed of the cause", he later explained to a parliamentary committee. "I mentioned my object and my sentiments publickly and in all companies. It was a notorious fact that I came here with that view". ${ }^{82}$ The immediacy and seriousness of his intentions, however, were not immediately apparent, and initially merchants willingly met with him. Thanks to the elder Rathbone, Clarkson gained introductions to respected locals involved in the trade, such as merchant Ambrose Lace, former slaving captain Robert Norris and Common Council member Edward Chaffers. Unfortunately, Clarkson struggled to contain the contempt and anger he felt towards the slave trade and those involved in it. Upon breakfasting with Rathbone, Lace and Chaffers, Clarkson impetuously accused Lace of participating in a well-known massacre on the Calabar River in $1767 .{ }^{83}$ The outburst sufficed to raise the alarm amongst the port's slaving interest. Thereafter Clarkson became the subject of daily

${ }^{80}$ Ibid., pp. 375-77.

${ }^{81}$ Clarkson's illustrated pamphlet was titled: An Accurate Account of that Horrible and Inhuman Traffic the Slave Trade... with a Description of the Iron Instruments used in this Abominable Traffic. See Marcus Wood, "Packaging Liberty and Marketing the Gift of Freedom", in Stephen Farrell, Melanie Unwin and James Walvin (eds.), The British Slave Trade: Abolition, Parliament and People, Edinburgh, 2007, pp. 220-22.

82 Board of Trade, Report of the Lords of the Committee of Council appointed for the Consideration of all Matters relating to Trade and Foreign Plantations, London, 1789, p. 72.

83 Sanderson, 'Liverpool Abolitionists', p. 208; PP, Accounts and Papers, 1790, XXIX. Minutes of the Evidence: Select Committee on the Slave Trade., p. 636. 
harassment, and discovered that witnesses would no longer meet with him publicly or agree to testify. ${ }^{84}$ By late October, finding that he could make no headway and, recalled by the London Committee, Clarkson left Liverpool.

The Liverpool slaving merchants mobilise

The alarm caused by Clarkson's 1787 visit to Liverpool was short lived. While the abolitionist remained in the Mersey port, merchants made a point of dining at the King's Head, where he lodged and dined in public. Each evening, his History relates, slaving merchants and captains would draw him into discussion, attempt to persuade him against abolition and when they failed, resort to berating him. ${ }^{85}$ The evidence suggests, however, that any concerted effort to defend the slave trade that materialised during Clarkson's stay faded after his departure in late October 1787. Although the offended merchants still harboured resentment towards Clarkson, as indicated by Currie, they became complacent in regard to abolitionist advances across the country and in the capital. The Manchester Mercury, a newspaper sold in Liverpool, published attacks on the slave trade from November 1787, yet the Liverpool press did not retaliate with anti-abolitionist references until mid-January 1788. Moreover, the minutes of the Common Council indicate that it did not address the issue of abolition until another month after that. ${ }^{86}$

The signal for Liverpool's slaving merchants to organise came in early February 1788. On 3 February, Liverpool merchant John Tarleton met with Prime Minister William Pitt. As Sanderson discusses, Tarleton was in London on business and appears to have requested the meeting on his own initiative, hoping to persuade Pitt of the inadvisability of abolition. The general expectation was that Wilberforce would soon motion the House of Commons to condemn the slave trade, and if successful, would then present a Bill for its abolition. ${ }^{87}$ To Tarleton's surprise, Pitt revealed that he favoured the abolition of the slave trade. Tarleton lost no time in spreading the bad news, writing immediately to the Mayor of Liverpool, Thomas Earle. Two days later he shared his pessimism about the slave trade's future with his brother Clayton:

${ }^{84}$ Clarkson, History, Vol. I, pp. 384-88.

${ }^{85}$ Clarkson, History, Vol. I, p. 388.

${ }^{86}$ Sanderson, "Liverpool Delegates", pp. 58-9.

${ }^{87}$ Ibid., p. 59. 
I think we shall have little chance of success, or that the African Trade will remain on its present footing except we can prove that it is not carried on with that shocking inhumanity that is imagined by all ranks of Mankind out of doors. ${ }^{88}$

The need for an organised defence of the slave trade intensified further when Pitt announced on 11 February that the Trade Committee of the Privy Council would commence an investigation into allegations laid against the slave trade.

The Liverpool Common Council and African merchants sprang into action. Earle immediately replied to Tarleton, requesting that he remain in London to head an official delegation of Liverpool slaving merchants and captains. The Tarletons were a wellestablished slave-trading family and prominent Liverpudlians; John was a partner in Tarleton and Backhouse, one of England's top slave-trading firms. He was joined in London by Robert Norris, slaving captain-turned-ship owner James Penny, former slave purchasing agent John Matthews, and slaving captain Archibald Dalzell. The Council instructed the delegation to work alongside the London-based African Committee to select and groom witnesses to appear before the Privy Council Committee. ${ }^{89}$ Meanwhile, the Liverpool slaving interest responded to the steady flow of abolitionist petitions reaching the House of Commons, adopting a petition in defence of the slave trade at a Council meeting on 14 February. ${ }^{90}$ The following day the Privy Council Committee met for the first time. ${ }^{91}$

Comparisons are inevitably drawn between the respective contributions of Liverpool and London to the parliamentary defence of the slave trade. James Rawley argues that London's role in the slave trade's defence has been "both minimized and ignored by contemporaries and historians", in part due to Clarkson's focus on the Liverpool delegates. ${ }^{2}$ However, historical attention to Liverpool's contributions to the anti-abolition campaign has concentrated on the parts played by the town's MPs, and not on the organisational infrastructure behind them, Sanderson's 1972 article being an exception. Indeed, historians of abolition, such as Anstey and Porter, acknowledge the importance of Liverpool in the proceedings, but prioritise the activities of London based West Indians in their accounts of the pro-slavery reaction to abolition in 1787 and $1788 .{ }^{93}$

\footnotetext{
88 Ibid., "Liverpool Delegates", pp. 61-2.

89 Sanderson, "Liverpool Delegates", pp. 62-5.

90 According to Clarkson the Commons received thirty-five abolitionist petitions by mid-February, and Oldfield states that the House received 100 abolitionist petitions between 1 February and 9 May 1788. Clarkson, History, Vol. I, p. 470; Oldfield, Popular Politics, p. 49; Williams, Liverpool Privateers, p. 609.

${ }^{91}$ Huddleston, Children's Teeth, p. 371.

92 James Rawley London, Metropolis of the Slave Trade, Columbia, 2003, pp. 123-24.

93 Anstey, Slave Trade, pp.286-320; Porter, Abolition, pp. 16-29.
} 
Interestingly, contemporaries interchangeably described opponents of abolition as "West Indians", "slave traders", and the "Liverpool interest". 94

West Indian planters and merchants formed the largest London-based pro-slaving lobby. They were jointly represented in the capital by the Society of West India Planters and Merchants, which on 7 February created a subcommittee to mount a defence of the trade. The West Indians feared that the colonial plantation economy could not survive without annual imports of slaves from Africa. In organising witnesses to stand before the Privy Council, the West Indians had the advantage in being based in London and having a strong presence in Parliament. Moreover, West Indians could count on the support of MPs representing slave-trading interests, whereas slaving merchants could not necessarily expect their interests to align with the West Indians'. West Indian representation in the House of Commons was approximately four times that of the slaving merchants. ${ }^{95}$ An examination of the Minutes of the various inquiries held by the Commons between February 1788 and April 1791 reveals that West Indians produced nearly twice as many witnesses than British slave traders. ${ }^{96}$ Nonetheless, despite mustering fewer witnesses than the West Indians, the testimony organised by the Liverpool delegates proved instrumental in opposing abolition.

Liverpool anti-abolition witnesses opened the Privy Council inquiry. Their testimony addressed two broad issues: conditions on the Middle Passage and slave procurement in Africa. Former and current slave ship captains with years of experience behind them denied the horrific living conditions and violence to which abolitionists argued both slaves and crewmembers were subjected. Traders, previously stationed on the African coast, joined the captains in connecting the slave trade to African customs. They refuted the abolitionist notion that African leaders enslaved their own through warfare, kidnapping and unjust laws to profit from slave sales to Europeans. Instead they argued that these practices were endemic to African society and that the slave trade saved the enslaved from otherwise being executed. ${ }^{97}$ According to Clarkson, the Liverpool witnesses produced an immediate and widespread response in favour of the slave trade. Their testimony turned many Privy Council members against abolition, who in turn disseminated

94 Sanderson, “Liverpool Delegates”, p. 58; Anstey, Slave Trade, p.287.

95 Anstey, Slave Trade, p. 287. Whereas MPs for Bristol, Liverpool, Lancashire and London represented constituencies with interests in both the slave trade and the West Indies, MPs solely representing West Indian interests could not be counted on to support slaving merchants' interests.

96 A\&P, 1789, XXIV. Minutes of the Evidence taken before a Committee of the Whole House on Regulation of the Slave Trade; $A \& P, 1789$, XXV. Minutes of the Evidence taken before a Committee of the Whole House to consider the Slave Trade; $A \& P$, 1789, XXVI. Report of the Privy Council Committee on the Slave Trade; $A \& P, 1790$, XXIX. Minutes of the Evidence: Select Committee on the Slave Trade; $A \& P$, 1790, XXX. Minutes of the Evidence: Select Committee on the Slave Trade. $A \& P, 1791$, XXXIV. Minutes of the Evidence: Select Committee on the Slave Trade.

${ }_{97}$ Sanderson, "Liverpool Delegates", pp. 66-7. 
information through the higher echelons of society, convincing many more that the slave trade should continue. ${ }^{98}$

The Liverpool delegates' early success lay in their procurement of authoritative witnesses. In contrast to the abolition witnesses, the Liverpool witnesses testifying on conditions in the Middle Passage appeared more highly qualified. They had recent, extensive, and first-hand experience of the trade, and, as captains and merchants, were generally of higher social standing. ${ }^{99}$ The abolitionists struggled to produce witnesses with comparable experience. Between 1788 and 1791, seven men previously employed in the Liverpool slave trade gave evidence on the Middle Passage on behalf of abolition. Of these, John Newton had had the longest involvement in the trade, captaining five voyages, but had been out of the trade for thirty-four years. The others had undertaken one to two voyages each, four of them retiring from the trade prior to 1770 . The remaining two witnesses, Dr. Thomas Trotter and Mr. Ecroyde Claxton, had both been slave ship surgeons in 1783 and 1788 respectively, but did not testify until 1790 and 1791 . None of these men resided in Liverpool at the time they testified. ${ }^{100}$

The Privy Council's investigations continued until April 1789. Pitt had hoped to receive a report by May 1788 in order for abolition to be broached in the current session. There was little point in starting the debate before the evidence was ready, therefore on 9 May, standing in for an unwell Wilberforce, Pitt motioned the House to postpone addressing the slave trade until the next session in November. ${ }^{101}$ In the ensuing discussion, Lord Penrhyn and Bamber Gascoyne, the members for Liverpool, declared themselves in favour of the Commons conducting its own inquiry into the trade and open to a potential regulation of it. Lord Dolben, the member for Cambridge University, then suggested the trade's immediate regulation, arguing that a delay would unnecessarily cost thousands of slave and seaman lives. ${ }^{102}$ On 21 May, the House accepted Dolben's submission of an official draft of a Bill to regulate the slave trade; the debate renewed on $26 \mathrm{May} .{ }^{103}$

Despite their earlier proclamations, the Liverpool representatives did not respond favourably to the proposed Bill. Penrhyn repeatedly argued that the Bill served no practical purpose as merchants already had incentives to keep slaves healthy on the Middle Passage,

\footnotetext{
98 Clarkson, History, Vol. I, pp. 481-82.

${ }^{99}$ Sanderson, "Liverpool Delegates", p. 66.

100 See footnote 96.

101 Anstey, Slave Trade, pp. 267-69; James W. LoGerfo, "Sir William Dolben and "The Cause of Humanity": The Passage of the Slave Trade Regulation Act of 1788”, Eighteenth-Century Studies, Vol. 6, No. 4, Summer, 1973, pp. 433-34.

102 LoGerfo, "Dolben”, pp. 435-37.

103 LoGerfo, "Dolben”, pp. 439-40.
} 
and Gascoyne attempted to block the Bill by moving for a three-month postponement. ${ }^{104}$ On 28 May, Penrhyn introduced two petitions from Liverpool merchants and slave traders asking that their concerns be heard. ${ }^{105}$ As a private member's Bill, the House was under no obligation to hear evidence against it, but the merchants' request was granted. ${ }^{106}$ Between 2 and 17 June the Commons resolved itself into a Committee of the Whole House to hear evidence from the five Liverpool delegates and one Bristol delegate. According to Sanderson, the Liverpool witnesses were less effective before the Commons. The abolitionists, now familiar with their arguments, skilfully cross-examined them. Moreover, Pitt had had the foresight to dispatch an investigator to examine the dimensions of Liverpool slaving ships, an investigator who then could dispute slaving merchants' testimony, if inaccurate. ${ }^{107}$ On 16 June, despite Gascoyne's objections, the Committee refused to hear the London witnesses. The next day, Dolben's Bill passed its second reading by fifty-six votes to five. ${ }^{108}$

Having failed in the Commons, the Liverpool delegates turned their attention to the Lords. Tarleton pressed Lord Hawkesbury, the president of the Board of Trade and leader of the Privy Council's slave trade inquiries, to consider how Dolben's Bill would render the trade unprofitable. Meanwhile, Liverpudlians petitioned the House of Lords eight times against the Bill between 19 June and 10 July, but according to Currie, the delegates struggled to find a member to present their petitions. ${ }^{109}$ Encouragingly, the Lords re-examined Tarleton and Jones, and appeared favourably disposed to make concessions. The slave traders hoped that amendments made by the Lords would defer the Bill to the next session. Although the Bill passed once more through each of the Houses, it received royal assent on 11 July, the day Parliament recessed. ${ }^{110}$ The Slave Trade Regulation Act, or Dolben Act, came into effect on the 1 August 1788. It remained the most important piece of slave trade legislation enacted until the Slave Trade Abolition Act of 1807.

The Dolben Act is best remembered for restricting the number of slaves carried per ship's tonnage. The Liverpool MPs pleaded that allowing less than two adult slaves per ton would render the trade unprofitable, and force merchants to withdraw from it. ${ }^{111}$

\footnotetext{
104 LoGerfo, "Dolben", pp. 440-42; Dale H. Porter, The Abolition of the Slave trade in England, 1784-1807, Hamden, 1970 , p. 38.

105 LoGerfo, "Dolben”, pp. 440-41. Dorchester representative William Ewer also presented a petition from London slave traders, Porter, Abolition, p. 39.

106 Porter, Abolition, p. 39.

107 Sanderson, "Liverpool Delegates", p. 70.

108 Ibid., p. 71.

${ }^{109}$ Ibid., pp. 72-3. Bristol also sent three petitions, London sent two and West Indians sent two.

110 Porter, Abolition, p. 49.

111 Clarkson, History, Vol. I, p. 536.
} 
Nonetheless, the act limited vessels to carrying five slaves per three tons up to 201 tons, and one slave per ton thereafter, and instituted a fine of $f, 30$ per slave over the limit. Dolben's act is also noteworthy for the concern it showed to the wellbeing of slave-ships' crew and cargo. ${ }^{112}$ Captains' appointments were made subject to stringent prerequisite experience, and all ships were required to carry a certified surgeon, whose duty it was to keep a journal recording the deaths, as well as cause of death, of both sailors and slaves. The surgeon had to submit the journal to the port of arrival's customs officer under pain of a $£, 100$ fine. The act instituted bonuses of $£, 100$ pounds for captains and $£, 50$ for surgeons if fewer than two slaves died during the Middle Passage. ${ }^{113}$ To prevent a repetition of the Zong Affair, the Act made it illegal to insure against loss of slaves, with exceptions for acts of God, piracy and insurrection. ${ }^{114}$ The Dolben Act amendment of 1789 instituted further regulations to protect Guinea sailors contractually, and to improve their shipboard health. Parliament subsequently renewed the Act year by year. ${ }^{115}$

At the end of July 1788 the five Liverpool delegates dispersed. In recognition of their efforts, the Council made them freemen of the borough "for the very essential advantages derived to the trade of Liverpool from their evidence in support of the African slave trade, and for the public spirit they have manifested on this occasion". ${ }^{116}$ The following year, only Norris and Penny resumed their roles as delegates, returning regularly to London from April 1789. Tarleton maintained contact with Hawkesbury and the African Company, but may have been prevented by illness from retaining a more active participation in the campaign. ${ }^{117}$ In December 1789 Norris and Penny again received the thanks of the Council for their work as delegates. ${ }^{118}$ Norris' death in 1792 ended the delegation. That December the Council bestowed a lifetime annuity of $f_{1} 100$ per year on Norris's wife, and gifted Penny a $£ 100$ plate after he refused compensation. ${ }^{119}$

\footnotetext{
112 In his 1993 Ph.D. Thesis Behrendt argues that interest in shipboard diseases and disease transmission stemming from the high death rates sustained during the war on the Channel fleet and the West India station (1780-1782) partially accounts for MPs receptiveness to Dolben's proposed act. Behrendt, "The British Slave Trade, 1785-1807: Volume, Profitability, and Mortality,” Ph.D. Thesis, University of Wisconsin, Madison, 1993, p.158.

113 "An Act to Regulate the Carrying of Slaves, 1788" in Elizabeth Donnan (Ed.), Documents Illustrative of the History of the Slave Trade to America: Volume II: The Eighteenth Century, Buffalo, 2002, pp.582-589.

114 Sanderson, "Liverpool Delegates", pp. 75-6.

115 Behrendt, "British Slave Trade", pp. 163-64.

116 Williams, Liverpool Privateers, p. 611.

${ }_{117}$ Sanderson, “Liverpool Delegates”, p. 77.

118 Williams, Liverpool Privateers, p. 612.

119 Sanderson, "Liverpool Delegates", pp. 79, $84 n 79$.
} 
The slave trade as a source of Liverpool unity

Drescher argues that the opprobrium cast on Liverpool by the British public in 1787-1788 reaffirmed internal solidarity within Liverpool society. This was to be seen in the toasts made to the slave trade during formal dinners and public functions, or through the ringing of church bells to celebrate big abolitionist defeats in Parliament. It also united Liverpudlians in counter-attacking the abolition movement. ${ }^{120}$ Liverpool, alone of the British slave trading ports, produced counter-petitions to abolition in the name of its inhabitants. ${ }^{121}$ It could also be argued that the large groundswell of support pressured some individuals into actively participating in the anti-abolition campaign, as suggested by Norris' controversial decision to become a Liverpool delegate. In addition, participation in the anti-abolition campaign also could be a means of seeking social integration into Liverpool society, as demonstrated by Reverend Raymond Harris's publication of a religious defence of the slave trade in early 1788 .

Norris's involvement in the anti-abolition campaign has caused confusion since 1788. The well-known story is as follows. When Clarkson met Norris in Liverpool in September 1787, the former slave ship captain spoke in favour of the abolition of the slave trade. The two men met a half-dozen times to discuss the slave trade, African society and Africa's "legitimate" trade potential in produce, such as ivory, dyewood, spices or palm oil. According to Clarkson, Norris confirmed the African practice of kidnapping to supply slave ships, and listed suggestions by which Parliament could achieve abolition. ${ }^{122}$ Since Norris had been Clarkson's most important informer in Liverpool, when Pitt announced the Privy Council's investigation into the slave trade in February 1788, Clarkson wrote to Rathbone III, pleading him to convince Norris to testify for abolition. Rathbone's response shocked Clarkson: Norris was already in London, representing Liverpool slave traders. $^{123}$

Sanderson has questioned why Norris would have favourably discussed abolition with Clarkson when he had maintained a strong connection to the slave trade since retiring from it. Between 1770 and 1778, Norris made five voyages from Liverpool as a slave ship captain, buying slaves in the Bight of Benin and selling them either in Jamaica or South Carolina. After his second voyage in 1772, he had earned sufficient money in the slave

\footnotetext{
120 Drescher, "Slaving Capital", p. 133.

121 Drescher, "Public Opinion", p. 49.

122 Clarkson, History, Vol. I, pp. 378-82.

123 Ibid., pp. 478.
} 
trade to invest capital in the remainder of his voyages. ${ }^{124}$ Sometime after 1778 , Norris started a tool-making factory, but his correspondence suggests that he may have still been officially involved with the African Company as he weighed in on prospective employees, updated the company on Liverpool trading, and advised it on the provisioning of Cape Coast Castle. ${ }^{125}$

It is unclear what motivated Norris to initially support Clarkson's research and sympathies. Perhaps the retired slaving captain had, by 1787, started to consider abolition. Prior to meeting Clarkson, he had read the abolitionist's Essay on the Slavery and Commerce of the Human Species. ${ }^{126}$ It is equally likely that the Liverpool slaving interest convinced him to represent their cause. Knowledge of Norris's discussions with Clarkson would have spread, the men having met on several occasions in private and in public. Recognising Norris's value to the abolitionists, Liverpool slaving merchants might have made it worth Norris's while not to testify against them by promoting his career and rewarding his service: in 1788 Norris introduced himself to the Privy Council as a "Carolina Merchant", but in 1790 he described himself to Lord Hawkesbury as the commercial agent for Liverpool. ${ }^{127}$ Once on side with the slaving faction, Norris supported the slave trade whole-heartedly, with Rediker describing him as one of its "very best public defenders". In 1788, Norris anonymously published $A$ Short Account of the Slave Trade, republished the following year with corrections, and also included in his 1789 history of Dahomey (Benin), Memoirs of the Reign of Bossa Ahádee, King of Dahomy. ${ }^{128}$

Norris repeatedly described a sense of having no alternative but to join the delegation. He explained to Clarkson in 1788 that upon reflection he had found he did not entirely agree with Clarkson's abolitionism and "had therefore less reluctantly yielded to the call of becoming a delegate" although he would have "gladly declined the office if he could have done so with propriety". Later, he would tell the Commons that he had not attended the meeting at which he had been appointed to the delegation, and that it had been done without his consent. ${ }^{129}$ Upon the stand, Norris contradicted the evidence he had given Clarkson just a few months earlier, denying kidnappings and presenting an idyllic

\footnotetext{
124 Slave Trade Database. The database indicates six voyages, but the 1776 voyages of the Unity and the Britannia, both listing Norris as captain, overlap.

125 Sanderson, "Liverpool Delegates", p. 63.

126 P.P., Accounts and Papers, 1790, XXX. Minutes of the Evidence: Select Committee on the Slave Trade, p. 66.

${ }^{127}$ Sanderson, "Liverpool Delegates”, p. 63.

128 Marcus Rediker, The Slave Ship: A Human History, London, 2007, p. 31.

${ }^{129}$ Sanderson, "Liverpool Delegates", p. 80n21.
} 
image of the Middle Passage. ${ }^{130}$ In 1790, the conflict between Clarkson and Norris having entered the public debate, the Commons cross-examined both men's testimony of their encounter. According to Clarkson, his account shamed Norris who "neverafterwards held up his head, or looked to abolitionists in the face, or acted with energy as a delegate, as on former occasions". ${ }^{131}$ When Norris died in 1792, the Common Council honoured his zealous defence of the slave trade. Norris's tireless efforts had been "instrumental" to their cause. The Council suggested that the abolitionist backlash he endured after the Clarkson episode contributed to his premature death.

In early 1788, as Norris and the other delegates were preparing for the Privy Council inquiry, Reverend Raymond Harris published the first religious defence of the slave trade. It soon emerged that author of Scriptural Researches on the Licitness of the Slave Trade was in fact Don Raymondo Hormaza, a Spanish Jesuit priest in exile. ${ }^{132}$ Since settling in Liverpool, Harris had argued with the local Catholic priest, who suspended Harris's priesthood, but was otherwise in good standing with the community and ran a school for young men. Harris separated the issue of slavery from the issue of abuses and malpractices that occurred within it, and argued that the Bible did not intrinsically declare slavery unlawful. According to David B. Davis, the lucidity and logical development of Harris's arguments made him a "formidable opponent" to abolitionists. ${ }^{133}$ As Currie had to admit, Harris's work was 'in truth no bad specimen of his talents, tho' egregiously false and sophistical". ${ }^{134}$

Abolitionist responses to Harris seized on his alien-ness, but the pro-slaving lobby promoted his contribution to their cause. In an anonymous denunciation of Harris's pamphlet, Roscoe, who had been commissioned by the London Committee, flatly stated that Harris's arguments were "totally irreconcilable to the character of an English-man" but were "perfectly consistent with that of a Spanish Jesuit". ${ }^{135}$ The Common Council, however, rewarded Harris's support of the slave trade. In June, the Council thanked him for his "excellent publication" and awarded him $£_{100}$ "as a mark of the high sense this Council entertains of the advantages resulting to the town and trade of Liverpool from the

\footnotetext{
${ }^{130}$ Clarkson, History, Vol. I, p. 479-80; Rediker, Slave Ship, pp. 31-2.

131 Clarkson, History, Vol. II, pp. 182-83.

132 Raymond Harris, Scriptural Researches on the Licitness of the Slave Trade, Shewing its Conformity with the Principles of Natural and Revealed Religion, Delineated in the Sacred Writings of the Word of God, London, 1788.

133 D. B. Davis, The Problem of Slavery in the Age of Revolution, 1770-1823, Ithaca, 1975, p. 544.

${ }^{134}$ Quoted in Sanderson, "Liverpool Abolitionists", p. 213.

135 Davis, Problem, p. 546; Drescher, "Slaving Capital", pp. 133-34. The Roscoe's Circle responses to the Scriptural Refutations will be further developed in Chapter Two.
} 
said publication". ${ }^{136}$ The slaving faction extensively advertised Scriptural Researches in Liverpool and London, and the work was notably promoted by Lord Hawkesbury, who argued that Harris's arguments were unanswerable. ${ }^{137}$ This view was shared, Clarkson claimed, by many important men who received copies of the pamphlet from the Liverpool slaving interest. ${ }^{138}$

By 1787-1788, then, defending the slave trade in Liverpool had become more than just a means of showing civic pride and unity — it provided the means through which even an outsider could integrate into local society. The Common Council demonstrated its commitment to protecting the slave trade by using town funds to reward those who helped in the fight against abolition. Although Harris's pamphlet was never republished, Liverpool society in general was not swayed by the abolitionist attacks on his foreign origins. When Harris died in 1789 , his obituary honoured him as a respected Liverpool citizen. ${ }^{139}$

\section{Conclusion}

In February 1788, Liverpool merchant Edgar Corrie secretly wrote to Lord Hawkesbury offering his support for abolition. Corrie was a member of Liverpool's Chamber of Commerce, and he provided Hawkesbury with an anonymous memorandum arguing a commercial case for abolition. Corrie indicated that, although few in number, there were other members of the chamber who were opposed to the slave trade, but that it would be the duty of Parliament to "reverse the prejudices of the Town of Liverpool by unquestionable evidence". Corrie explained that his business would be ruined if anyone in Liverpool were to discover that he supported abolition, and he therefore begged Hawkesbury not to share his letter with anyone but Prime Minister William Pitt. ${ }^{140}$ Corrie made it clear that the depth of anti-abolitionist feeling in Liverpool made it necessary for the abolition issue to be decided by a higher authority than local politics. His letter demonstrated that if Liverpool abolitionism appeared non-existent, it was because very few were willing to risk raising their voice against a trade that so many of the town's

\footnotetext{
136 Quoted in Davis, Problem, p. 543.

137 A. Wilson, Roscoe, p. 131.

138 Davis, Problem, p. 543.

139 Drescher, "Slaving Capital", p. 133.

140 Robert J. Bennett, The Voice of Liverpool Business: The First Chamber of Commerce and the Atlantic Economy, 1774c.1796, Liverpool, 2010, p. 50.
} 
councilmen and workers viewed as a necessary component to Liverpool's continued prosperity. 


\section{CHAPTER TWO}

\section{THE ROSCOE CIRCLE AND EARLY LIVERPOOL ABOLITIONISM, $1787-1788$}

In early 1788, the London Abolition Committee published a list of subscribers that recognised the support of eight Liverpudlians: William Roscoe, William Rathbone III, William Rathbone IV, Dr. Jonathan Binns, Rev. John Yates, William Wallace, Daniel Daulby, and an anonymous contributor now identified as Dr. James Currie. Since the London Committee's official formation in May 1787, towns across Britain, including Bristol, had shown their support for abolition by founding satellite committees. Liverpool was a notable exception. Nonetheless, as the list showed, the movement was not without supporters in the slave trading capital. In fact, members of the Roscoe Circle, a Liverpool group of rational dissenters, had quietly contributed to the campaign during the previous year, remaining anonymous to all but the London Committee. Public knowledge of each member's abolitionist sympathies varied, but on the whole they were discreet, and were careful to keep their active participation below the radar.

The list of subscribers, distributed by the London Committee with a pamphlet by Clarkson, represented the first indication to the public that a small abolitionist community existed in Liverpool. For most of the names on the list it also represented the first time they publicly identified themselves as supporters of abolition. The list is interesting because not all the names hold equal status in the historiography of Liverpool abolitionism. Historians generally focus on Roscoe and Currie, and on the two William Rathbones. Sources hint that Yates and, to a lesser extent, Binns were reasonably actively involved in the Roscoe Circle's abolitionist campaign but the evidence remains too scarce to gain a clear understanding of their roles. Finally, scarcity of evidence on Daulby and Wallace's involvement mean that they barely enter studies of Liverpool abolitionism. Not featured on the list are Liverpool abolitionists, and Roscoe Circle members, Edward Rushton or Henry Dannett.

This chapter examines the Roscoe Circle's involvement in the British abolition campaign during 1787 and 1788 . Historians disagree as to the significance of the Roscoe Circle's contributions to the national abolition movement. In 1928, Jean Trepp overstated 
the importance of these "few righteous souls" by arguing that they created in Liverpool a "miniature campaign analogous to the larger English abolition movement". In 1976, in the most important study of Liverpool abolitionism since Trepp, F. E. Sanderson diminished the group's historical significance, stating that the Roscoe Circle merely demonstrated "that Liverpool was not wholly bound by mercantile self-interest at this crucial point in history". 2 This chapter reconsiders the achievements and shortcomings of the Roscoe Circle in light of their motivations and goals, which did not mirror those of the London abolitionists.

\section{The Roscoe Circle}

The term Roscoe Circle is ahistorical and loose, and does not exclusively denote Liverpool abolitionists. Originally, historians equated the Roscoe Circle with the Literary Society, which operated from 1784 through to the early 1790s, and was formed principally for the discussion of literary topics. Recent scholarship explains that the Roscoe Circle, in fact, pre-dated the Literary Society, having emerged from a Unitarian network developed in the 1760s and operated until Roscoe's death in the early 1830s. The members of the Roscoe Circle were active in local and national radical politics and were dedicated to promoting the arts, sciences and education. Religious dissenters, they were mostly Unitarian, although a couple of members were Anglican. Historians of Liverpool abolitionism have often used the term "Roscoe Circle" interchangeably with "Literary Society" or "Liverpool abolitionists". It is important, however, to note that abolitionism was just one of many causes espoused by Roscoe Circle members, and that not all members supported it. Nonetheless, for ease and clarity, this thesis will use the term "Roscoe Circle" to designate only abolitionist members of the Circle. ${ }^{3}$

Since there is no set list of who belonged to the Roscoe Circle, let alone of the abolitionist members one must focus on the contributions of the most prominent abolitionist members in 1787 and 1788. Most notable are William Roscoe and his good friend William Currie. Both men had their papers archived and, therefore, figure prominently in all histories of Liverpool abolitionism. The well-known Quaker merchants

\footnotetext{
1 Jean Trepp, "The Liverpool Movement for the Abolition of the English Slave Trade," Journal of Negro History, Vol.13, No.3, July 1928, pp. 265-85.

2 Sanderson, "Liverpool Abolitionists", p. 197.

3 Ian Sutton, "Roscoe circle (act. 1760s-1830s)", Oxford Dictionary of National Biography, Oxford University Press. [http://www.oxforddnb.com/view/theme/101301, accessed 19 May 2013].
} 
William Rathbone III and his son William Rathbone IV also feature in this study, along with the blind poet Edward Rushton, and, to a lesser extent, the Reverends John Yates and Henry Dannett, and the Quaker doctor Jonathan Binns. Fragmentary evidence suggests that at least several other Liverpudlians supported abolition, but for the most part very little is known about them, including their level of participation in the abolition campaign or whether they belonged to the Roscoe Circle. ${ }^{4}$

William Roscoe, the group's namesake, remains the most well-known of the Liverpool abolitionists. ${ }^{5}$ Although self-educated, by the time of his death Roscoe had distinguished himself as a poet, historian and promoter of the arts and sciences for which he earned the reputation as a cultural icon of Liverpool. Closely connected to the Liverpool Unitarian community, his early writings impressed William Enfield, the minister of the Liverpool Unitarian chapel. Enfield later became rector of the prestigious Warrington dissenting academy, where Roscoe attended meetings and found a publisher for Mount Pleasant in 1777. ${ }^{6}$ Of humble origins, Roscoe started his working life at age twelve in his father's alehouse and at fifteen was articled to a local attorney. In 1774, aged twenty-one, he was admitted as an attorney of the King's Bench and entered into partnership with Samuel Aspinall and Joshua Lace, both members of prominent slave trading families. ${ }^{7}$ In 1783, Roscoe's friend, the Quaker John Barton, moved to London where he helped form an informal Quaker abolition society. In their regular correspondence, Barton, who later was a founding member of the London Abolition Committee, kept Roscoe abreast of abolitionist developments in the capital and encouraged Roscoe's input in the movement.

While Roscoe's disapproval of the slave trade was longstanding, historians believe that Currie did not develop abolitionist sympathies until the early 1780s. A Presbyterian Scot, Currie had immigrated to North America in 1771, where he had been apprenticed to a Virginia merchant. ${ }^{8}$ Fleeing the American Revolution in 1776, he spent a brief time in the West Indies, before returning to Scotland in 1777. In 1780, after obtaining his medical diploma from Edinburgh, he arrived in Liverpool where, in recognition of his services he was later elected to the Dispensary and the Infirmary. ${ }^{9}$ Historians have described Currie as the Roscoe Circle's sharpest intellect, but have questioned his commitment to abolition, as

\footnotetext{
4 This thesis does not examine William Shepherd, a later Roscoe Circle abolitionist, as he was not in Liverpool during 1787-88, or the female abolitionist poet Eliza Knipe, although she may have belonged to the extended Roscoe Circle, see Littlewood, The Roscoes, pp. 881-82.

5 William Roscoe, b.1753 - d.1831.

6 Donald A. Macnaughton, "Roscoe, William (1753-1831)", Oxford Dictionary of National Biography, Oxford University Press, 2004. [http://www.oxforddnb.com/view/article/24084, accessed 1 June 2013]

${ }^{7}$ Littlewood, The Roscoes, p. 27; Huddleston, Children's Teeth, p. 330.

${ }^{8}$ James Currie, b.1756 - d.1805.

${ }_{9}$ Littlewood, The Roscoes, p. 71.
} 
there is no record of him condemning slavery after his West Indian experience. ${ }^{10}$ His father-in-law, William Wallace, one of the named subscribers to the London Committee, is believed to have fostered Currie's abolitionism in or around $1783 .{ }^{11}$ Currie's developing friendship with Roscoe would have further promoted his support for abolition. In 1780, Currie presided over the short-lived Liverpool Literary and Philosophical Society, to which Roscoe had not been invited to join. After the Society failed in late 1783, Currie and Roscoe together helped form the Literary Society in $1784 .{ }^{12}$

The Literary Society purported to exclusively discuss literary and scientific subjects, although historians believe that they also would have debated politics, and abolition. ${ }^{13}$ Members, many belonging to the Roscoe Circle, convened informally at each other's houses for regular intellectual discussions. Although not every member of the Literary Society supported abolition, each Liverpudlian who contributed to the campaign in 1787 and 1788 belonged to the Literary Society. Sanderson, in fact, suggests that between 1787 and 1789 the Literary Society functioned as if it were an unofficial branch of the London Committee, with "interested" members presenting their poems and pamphlets for review before sending them to the abolition leaders in London. ${ }^{14}$

The Literary Society clearly promoted the Roscoe Circle's early participation in the developing abolition campaign. Considering the religious values and political outlook of the Roscoe Circle it is unsurprising that they discussed the slave trade. More interesting, however, is that several members contributed to the abolition movement before it had even become a matter of public knowledge. At least two members of the Roscoe Circle were in contact with London abolitionists, and the Literary Society provided them with a venue to share and discuss news of the nascent movement. In addition to the information Barton supplied to Roscoe, the London abolitionists had informed the elder Rathbone in late 1786 of their intentions to attack the slave trade when they requested he copy the Liverpool muster rolls for Clarkson. It is no coincidence that Rathbone's cooperation with the London Committee was shortly followed by the publication, in early 1787, of two abolitionist poems, by Liverpool Society members William Roscoe and Edward Rushton, before knowledge of the burgeoning campaign was widespread.

\footnotetext{
10 Sanderson, "Liverpool Abolitionists", p. 205.

11 Sanderson, "Liverpool Abolitionists", pp. 203-4; Howman, “Abolitionism”, p. 281; W. Currie, Memoir, pp.

$3,10,28,40,57,75-6$.

12 Littlewood, The Roscoes, p. 63, 66.

13 A. Wilson, Roscoe, pp. 26, 42.

14 Sanderson, "Liverpool Abolitionists", p. 211.
} 
Two poems: The Wrongs of Africa and West Indian Eclogues

In early 1787, Roscoe and Rushton ranked among the first provincial contributors to the British abolition movement. Both natives of Liverpool, they had reflected on the slave trade and slavery in earlier poetical works, but the 1787 poems The Wrongs of Africa by Roscoe and West Indian Eclogues by Rushton marked both poets' first concentrated attacks on the slave trade and West Indian slavery. Their focus on colonial slavery rather than the slave trade itself reflects the poets' disconnect from the London Committee and its strategy to specifically target the evils of the slave trade and not the institution of slavery. While they may have presented their poems to the Literary Society, Roscoe and Rushton do not appear to have concerted their efforts as the works contrast both stylistically and in their manner of publication.

The Wrongs of Africa confronted slavers' justification of the slave trade and traced European avarice's corrupting and destructive influence on innocent Africans. Providing a romantic view of African society before European intervention, Roscoe described Africans living in functioning communities, engaging in delicate crafts, and knowing loving familial relationships. Demonstrating that kidnapping was a well-known method of slave procurement to Liverpudlians, he accused Europeans of disrupting Africans' "guiltless life" by inciting them to turn against each other, to sell their friends into slavery, and to wage war on unsuspecting villages for profit. ${ }^{15}$ Roscoe also revealed knowledge of the cruelty inflicted on slaves during the Middle Passage, and deplored that tyrannical captains would never be punished for their use of "instruments of torture, whips, and bonds" against their captive cargoes. ${ }^{16}$

Roscoe's denunciation of the double-standard that saw Britons advocate liberty at home yet violently oppress others abroad, would be echoed by Clarkson in a November 1787 letter to the times relating his discovery of instruments of torture in a Liverpool shop. "Blush ye not", Roscoe challenged,

To boast your equal laws, your just restraints, Your rights defin'd, your liberties secur'd, Whilst with an iron hand ye crush to earth The helpless African; and bid him drink That cup of sorrow, which yourselves have dash'd

\footnotetext{
15 Roscoe, The Wrongs, p. 11.

16 Ibid., pp. 18, 6.
} 
Indignant, from oppression's fainting grasp?17

Roscoe implored his readers not to ignore the British slave trade: all Britons were responsible, and ultimately all would be judged by a higher power. ${ }^{18}$ Similarly, Clarkson's letter called the slave trade a "reproach to the national character", yet the newspaper's editor re-directed the blame away from the public, expressing the hope that the upcoming parliamentary inquiry would place "a proper stigma [...] upon the prosecutors [of the trade]". ${ }^{19}$

Roscoe enlisted Currie to write a preface to The Wrongs, which defined immediate abolition of the slave trade as the object of the poem. Currie urged a "wise" government to immediately end the slave trade, for sooner or later "the voice of reason, aided by the natural feelings of the human heart must [...] achieve its overthrow". ${ }^{20}$ Stepping away from the humanitarian tone of the poem, Currie highlighted a shocking rationale of the slaving interests: British slaving merchants and West Indian planters wanted the shocking colonial slave conditions to continue, as a natural increase in slave populations would, on the one hand, destroy merchant demand, and on the other hand, increase the cost of slaves. It would cost the planter more to raise a slave from infancy than to purchase one from a slaving ship. ${ }^{21}$ Nonetheless, Currie excused some slave traders, blaming the "combined influence of custom, of prejudice, and of interest" that afforded instances "not only of the corruption of the heart, but of the perversion of the understanding". This inability to understand the immorality of their actions, he stated, explained how some men "deeply engaged" in the slave trade were "in other respects, men of honour and integrity; and even [...] of humanity". 22

According to Scott Krawczyk, Currie's introduction served to tone down the moral indignation Roscoe expressed in the poem. Although Roscoe remained uncompromising in his condemnation of sadistic slave traders and slave owners, Currie pointedly remarked that the poet did, in fact, understand that not all involved could be charged with “deliberate wickedness". Thus, Krawczyk argues, Currie's introduction acted as a "rhetorical filter" to help the poem appeal to a more ambivalent audience and, equally, to humanise slave traders and owners to the more radical abolitionists in London. ${ }^{23}$

\footnotetext{
${ }^{17}$ Roscoe, The Wrongs, p. 32.

18 Sanderson summarises the poem in "Liverpool Abolitionists", p. 229.

19 The Times, 22 November 1787, p. 3.

${ }^{20}$ Roscoe, The Wrongs, p. iv.

${ }^{21}$ Ibid., p. vi.

22 Roscoe, The Wrongs, p. vi.

${ }^{23}$ Krawczyk, "Mediating Abolition”, pp. 213-15.
} 
Rushton's West Indian Eclogues rejected Roscoe's romanticism, offering an uncensored depiction of the horrific conditions in which West Indian slaves laboured, and demonstrated uncommon anti-racism in his treatment of Africans. Racism typically informed portrayals of Africans in anti-slavery poetry of this period. Poets depicted Africans as inferior, docile subjects, lacking definable character traits, and wholly passive in their enslavement. Rushton, however, vested his African protagonists with strong identities, and enabled them to voice rage at their enslavers and pursue revenge against their captors. ${ }^{24}$ His treatment of British hypocrisy, for instance, demonstrates the effect of his anti-racism. Jumba, a slave on a West Indian plantation, addresses the issue after his friend Adoma relates how his partner was whipped for taking a minute to breast-feed their dehydrated infant child, whom she carries on her back whilst labouring in the field.

Barb'rous deed!

Oh I for the pow'r to make these Tyrants bleed!

These, who in regions far remov'd from this,

Think, like ourselves, that liberty is bliss,

Yet in wing'd houses cross the dang'rous waves,

Led by base av'rice, to make others slaves:-

These, who extol the freedom they enjoy,

Yet would to others every good deny:

These, who have torn us from our native more

Which (dreadful thought!) we must behold no more:-

These, who insult us through the weary day,

With taunts our tears, with mocks our griefs, repay:

Oh! for the pow'r to bring these monsters low,

And bid them feel the biting tooth of woe! 25

Jumba is not Roscoe's "helpless African". He does not feel sorry for himself or ask for pity. He wants action; he wants to enact violence against his oppressors. In short, he exhibits the same emotions as would the British "monsters" if their roles were reversed.

Rushton's first-hand experience of the slave trade and West Indian slavery informed his anti-racist viewpoint. Apprenticed at a young age to the Liverpool shipping firm Watt and Gregson, Rushton earned the position of second mate on one of their slave ships by the time he was sixteen. A well-known story relates that Rushton had befriended an African crewmember, Quamina, on a West Indiaman, who drowned saving Rushton's life. Rushton repaid Quamina's sacrifice by aiding an ophthalmia-infected slave-cargo, which

\footnotetext{
${ }^{24}$ Howman, “Abolitionism”, p. 284.

${ }_{25}$ Edward Rushton, "West Indian Eclogues", in Alan Richardson (ed.), Verse: Volume 4, J. Kitson and Debbie Lee (eds.), Slavery, Abolition and Emancipation: Writings in the British Romantic Period, London, 1999, p. 33.
} 
the captain refused to help. Unfortunately, Rushton contracted the disease and became blind. Retiring from sea, Rushton resided in Liverpool where he worked as a tavern-keeper, newspaper editor and then bookseller. ${ }^{26}$ Unlike Roscoe and Currie, he was not afraid to sign his name to his abolitionist poem.

Since Rushton was famously outspoken against the slave trade, his lack of contribution to the abolition movement after 1787 is puzzling. Rushton's eulogist, William Shepherd, attested to the poet's membership to the Literary Society and praised his open abolitionism:

At that time [1787], to speak irreverently of the king, or even to deny the existence of a God, were, in the town of Liverpool, venial offences, when compared with the atrocity of condemning the sale and purchase of human flesh. In defiance, however, of popular clamour, Mr. Rushton was unreserved in stating his opinions on this subject. ${ }^{27}$

Known to have been more radical and vocal than his fellow Roscoe Circle members, historians have suggested that his blindness and poverty not only made him a marginalised member of the Circle but also offered him some protection against reprisals. Shepherd's eulogy also supplements Clarkson's account of his interaction with Rushton, indicating that Rushton met with Clarkson several times, supplying him with information and directing his research. The problem historians still face is elucidating why Rushton did not do more for abolition. As an already widely recognised abolitionist in Liverpool, why did he never try to organise an abolitionist petition? More importantly, why did he not volunteer as a witness for abolition in the parliamentary inquiries? As a retired Liverpool slave-trade sailor, he would have made an excellent candidate.

Although the timing of both poems' publication anchored them in the early abolition movement, only Roscoe demonstrated a desire to associate his work with that of the London Committee. In March 1787, having composed the first part of The Wrongs of Africa, Roscoe asked his friend Barton to organise the poem's publication in London. On 7 June, barely two weeks after the London Committee's formation, Barton informed the London abolitionists that Roscoe wanted to donate his poem's profits to the Committee. ${ }^{28}$ "To find friends to our cause", Clarkson later described, "rising up from a quarter, where

\footnotetext{
26 The Oxford Dictionary of National biography dates both voyages to 1773, Royden, "Rushton", ODNB; Rev. William Shepherd, "Life of Edward Rushton", in Edward Rushton, Poems and Other Writings By the Late Edward Rushton, London, 1824, pp. xi-xvii [xxi].

27 William Shepherd, "Life of Edward Rushton”, pp. xiv-xv [xviii-xix].

28 London Committee Minutes, 7 June 1787, BL Add MS 21254. Rathbone’s assistance in providing Clarkson with the Liverpool muster rolls represents his most important contribution to the abolition campaign. The significance of Clarkson's muster roll research will be developed later in the chapter.
} 
we expected scarcely any thing but opposition, was very consolatory and encouraging". ${ }^{29}$ The Committee voted its thanks to Roscoe, but displayed no knowledge that their friends of abolition in Liverpool were more numerous. Clarkson did not discover the existence of Rushton's West Indian Eclogues until September: when travelling through Lancashire he was told of the Liverpudlian brave enough to publish an anti-slavery poem under his own name. ${ }^{30}$ In a curious twist, though, Clarkson's friend, the Quaker printer and bookseller James Phillips, also a founding member of the London Committee, was Rushton's London distributor.

It is difficult to assess the influence either poem had on attitudes in Liverpool, as both were printed in London. As Rushton signed his name to the Eclogues it is likely that his poem had some impact on local society, as demonstrated by the reference made to Clarkson in Lancashire. There are no indications that Roscoe's The Wrongs stood out against other anti-slavery poems published at the time, and since he carefully withheld his name from the poem there would have been little reason for it, specifically, to be discussed in Liverpool. Designed to contain three parts, Roscoe published the second part in early 1788, but never wrote the final third. ${ }^{31}$ The Wrongs received generally favourable reviews, and Roscoe later discovered that his poem had been translated into German. ${ }^{32}$ In May 1788, Barton reported that, according to the publisher, both poems had at least earned sufficient profits to cover their production costs. ${ }^{33}$

\section{Clarkson and the Roscoe Circle}

Clarkson's History, still the leading source of information on the early years of the British abolition movement, presents little specific information on Liverpool abolitionism. Clarkson described struggling to find people in Liverpool who would publicly support abolition. Sympathisers, he found, were less forthcoming than in Bristol. They would often privately share their hopes for the movement's success, but otherwise refused to be seen publicly in his presence. Unfortunately, it is impossible to know to whom Clarkson

\footnotetext{
${ }^{29}$ Clarkson, History, Vol. I, pp. 279-80.

30 Ibid., p. 373.

31 Sanderson, "Liverpool Abolitionists", pp. 228-29.

32 Barton to Roscoe, 28 September 1787, LRO 920/ROS/248; H. Roscoe, Life, p. 82. He received at least one negative review from the editor of the English Review in late 1787, Barton to Roscoe, 22 November 1787, LRO 920/ROS/251.

33 Barton to Roscoe, 26 May 1788, LRO 920/ROS/254; Sanderson, “Liverpool Abolitionists”, p. 229.
} 
referred. How many secret abolition well-wishers did he meet? What class of people did they belong to? Were they only Roscoe Circle members? His lack of specificity in describing Liverpool supporters of abolition raises more questions than answers. From the very little attention Clarkson accords Roscoe, Currie, Rushton and the Rathbones, a reader of his History would not conclude that any form of organised abolitionism existed in Liverpool at this time.

As recounted in his History, upon arrival in Liverpool in September 1787, Clarkson boldly introduced himself to a few members of the Roscoe Circle. Apparently unaware of the existence of the Literary Society, Clarkson sought out Liverpudlians he knew to have a connection to abolition. He started, therefore, with Rathbone III, the man who had supplied him with Liverpool muster rolls. Next he visited Roscoe, author of The Wrongs of Africa. Roscoe, in turn, introduced Clarkson to Currie. Roscoe, in fact, had been forewarned of Clarkson's visit to Liverpool by his friend Barton. Finally, Clarkson called upon one man with whom he had no previous connection, Edward Rushton. ${ }^{34}$

The History gives readers the impression that the Liverpool abolitionists might not have enthusiastically welcomed Clarkson into their group. If we take Clarkson literally, Roscoe, Rathbone, Rushton and Currie did not introduce him to their circle of friends. Clarkson explains that they were the only people he knew in Liverpool for quite some time after his arrival. He does not indicate that he knew that they belonged to a Literary Society. ${ }^{35}$ In fact, other than associating Currie with Roscoe, he did not link the men. Furthermore, when he does meet another Roscoe Circle member, the Quaker doctor Jonathan Binns, the introduction is made by a Quaker acquaintance of Clarkson's, and again, no connection is made to the others. ${ }^{36}$ Particularly surprising is Rathbone IV's absence from the History. Not only was he a Roscoe Circle member, a Quaker, and the son of Clarkson's main contact in Liverpool, but Rathbone IV was also a young, politically active radical like Clarkson. ${ }^{37}$ Considering Clarkson's purpose in Liverpool, it seems extraordinary that the two should not have met.

Rathbone IV's omission from the History is noteworthy because it indicates limitations to Clarkson's account of his experience in Liverpool. Although Clarkson described his time in Liverpool in some detail, he referred very little to the so-called "Liverpool abolitionists". He does not recognise any significant contributions from them

${ }^{34}$ Clarkson, History, Vol. I, pp. 371-73.

35 Clarkson, History, Vol. I, p. 373.

36 Ibid., pp. 389-90.

37 According to Sanderson, Rathbone IV was "at the heart of virtually all the major political disputes in Liverpool during the latter part of the century", Sanderson, "Liverpool Abolitionists", p. 200. 
to his research and shows no understanding of their social network. It is possible, albeit unlikely, that Clarkson genuinely did not know about the role of the Literary Society in fostering Liverpudlian abolitionism. Why would four members of the Literary Society, who shared a set of ideals, not mention their collective support for abolition to Clarkson, or choose to meet with him as a group? A more probable explanation is that, at the time of writing his two-volume history of the abolition of the slave trade, Clarkson had to omit some information, prioritizing that which directly related directly to his research on sailor abuse and mortality. It is possible, also, that the Roscoe Circle did not approve of Clarkson's research, and chose to distance themselves from him.

Since late 1786, Clarkson had been inquiring into the health and welfare of British seamen employed in the slave trade. His examination of slave ship muster rolls from London, Bristol and Liverpool revealed that nearly a quarter of Guinea sailors died at sea. ${ }^{38}$ The discovery allowed Clarkson to focus public attention on the suffering of British men involved in the trade, thereby making the slave trade, which often appeared foreign and remote, an issue of local importance. His findings also countered the argument that the slave trade acted as a "nursery" for British seamen. Supporters presented the slave trade as a training ground for sailors wanting to enter the navy, thereby tying the trade to the continuing excellence and supremacy of the British navy, and by extension, to the protection of the British Empire. ${ }^{39}$ By comparing sailor losses in the slave trade to those suffered in other maritime trades, Clarkson responded that, far from being the "nursery" of British seamanship, the slave trade was in fact its "grave", destroying "more in one year, than all other trades of Great Britain, when put together, destroy in two". ${ }^{40}$

In Bristol and Liverpool, Clarkson discovered that Guinea sailors who survived the Middle Passage often returned home permanently debilitated from diseases and the physical abuse they sustained at sea. In Liverpool, in particular, the large numbers of blind, sick, and maimed returning-Guinea sailors drew Clarkson's attention, as did their noticeable presence in the infirmaries. ${ }^{41}$ Sailors were exposed to illnesses on the African coast and on-board from the slave cargo, but more shockingly, they were notoriously ill-

\footnotetext{
38 Muster rolls logged ships' voyage dates and crew names, as well as the dates of crew discharges, desertions or deaths at sea, and were mandatory for all voyages.

${ }^{39}$ Clarkson, An Essay on the Impolicy of the African Slave Trade, London, 1788, p. 31; Wood, "Packaging Liberty", pp. 222-23.

${ }_{40}$ Clarkson, Impolicy, pp. 49-53, 60-6.Clarkson presented his findings in An Essay on the Impolicy of the African Slave Trade published by the London Committee in 1788. To prove that the high mortality rate occurred from the nature of the trade and not solely from the African Climate, he compared crew losses with those sustained on other vessels visiting the African coast. He found that navy ships and wood-trading vessels that remained on the coast for longer periods of time than slave ships knew significantly lower death rates. Impolicy, pp. 68-74.

${ }^{41}$ Clarkson, Impolicy, pp. 58-9.
} 
treated in the slave trade by their superiors. In both ports, Clarkson interviewed Guinea sailors who testified to suffering on-going physical abuse at the hands of their captains and mates, which left crewmembers permanently maimed, if not dead. Moreover, Clarkson learnt that many sailors succumbed to their illnesses and injuries both in the West Indies and in British ports, causing him to estimate that as many as a third of British sailors died because of the slave trade. ${ }^{42}$ Tellingly, Clarkson conducted his research autonomously and does not appear to have requested assistance from Currie, despite his proximity to sick Guinea sailors through his involvement in both the Dispensary and the Infirmary.

Clarkson focused his Liverpool research on the on-board treatment of Guinea sailors by their captains and first mates. While in Liverpool, Clarkson says he spoke with almost every returning slave-ship sailor. With word of his purpose in the town spreading, he did not have to seek them out, as they came to him to share their stories of abuse at the hands of their captains. ${ }^{43}$ As in Bristol, he found that very few veteran sailors voluntarily entered the trade. Inexperienced young men most frequently comprised crews, enticed onboard by alcohol or promises of higher wages. Debt forced others into the trade. ${ }^{44}$ On board, captains beat and flogged their crew, sometimes to death, often with the illegal cato-nine-tails, a whip-like weapon made up of nine strips of knotted rope. ${ }^{45}$ Clarkson concluded that the slave trade changed men for the worse:

The unbounded power, which the captains of slave vessels possess, could be exercised but by few with propriety, and is in general too much for the human mind to bear, without degenerating into tyranny and oppression. The scenes too, which they must constantly be accustomed to behold, harden the heart, rob it of its finer feelings, and at length create a ferocity that, accompanied with the other effects, renders them rather monsters than men. ${ }^{46}$

\footnotetext{
42 Ibid., pp. 36, 55, 59.

43 Clarkson, History, Vol. I., p. 392.

${ }^{44}$ Clarkson, History, Vol. I, pp. 322-24, 393-94. Known as "crimping," captains arranged for boarding-house landlords to induce sailors to run up large debts they could not repay, and then offered them an ultimatum: board a slave-ship or go to jail, see Clarkson, Impolicy, pp. 31-3; Ibid., History, Vol. I, pp. 323-24.

45 Clarkson, Impolicy, pp. 34-6; Ibid., History, Vol. I, pp. 316, 325, 359-64, 427-34; Emma Christopher, Slave Ship Sailors and their Captive Cargoes, 1730-1807, New York, 2006, pp. 97-101. In his study of eighteenth century seamen, Rediker explains that the dispensation of discipline was the "necessary and bloody complement of the increasing productivity of seafaring labour" in this period and increased in all maritime trades, Rediker, Between the Devil and the Deep Blue Sea, Cambridge, 1987, p. 93.

46 Clarkson, Impolicy, p. 70. Clarkson highlighted the trade's effect on captains, but in her recent study, Christopher explains that it also modified sailor behaviour. Suddenly bestowed with power over their African cargo, sailors unwillingly employed in the trade and oppressed by their captain, could suddenly turn into vicious exploiters. Christopher, Captive Cargoes, p. 17.
} 
Examining seamen complaints against captains and mates for bodily abuse, Clarkson discovered that sixty-one of sixty-three were made by Guinea sailors. ${ }^{47}$

Clarkson's reliance on information provided by Guinea sailors disturbed the Roscoe Circle. As is well known, Currie voiced his discontent with Clarkson's actions in Liverpool in a letter to Wilberforce in December 1787. Clarkson, he argued, never gave the merchants an opportunity to explain their position, or to comment on the slave trade regulations they believed proper to instate. Referring to Clarkson, Currie wrote:

Men, purposely employed in acquiring information concerning [the slave trade] have shunned all intercourse with them, and drawn a great part of their intelligence from the lowest class of seamen. Nor is this all: conceiving that every enormity might be expected from the masters of vessels, who could conduct such a trade, they have listened eagerly to the accounts of their cruel usage of the seamen, and to the rumours of their dreadful barbarities of various kinds, with which [sic] uncommon integrity and kindness of heart. 48

Currie then explained that Clarkson's conduct unnecessarily alienated slave merchants who had planned on "meeting him, and giving him, openly and fairly, every assistance in their power", honestly believing their line of work was beyond reproach. Instead, Currie accused, Clarkson conducted his investigation in disguise and trusted the word of seamen, which alarmed the merchants into defensive action. ${ }^{49}$ Although only Currie's feelings towards Clarkson exist on record, historians agree that the other Roscoe Circle members most likely agreed with him..$^{50}$

Clarkson's arguments probably alarmed the Liverpool abolitionists as much as they did the Liverpool slaving faction. Clarkson recognised that he first attracted negative attention by publicly accusing Ambrose Lace of being involved in the notorious Calabar Massacre. Clarkson's outburst served to advertise his belief that slave merchants and captains should be held responsible for their roles in the slave trade. Sanderson argues that Clarkson's "blackguarding" of Liverpool slave merchants disturbed the Roscoe Circle because they feared that reprisals against the London abolitionist would reach them too. However, it is quite likely that they did not agree with Clarkson because, like the merchants, they understood the slave trade to be legal. As a judicial problem, therefore, the government should be targeted as opposed to those who simply operated within the law. As Currie's preface to the Wrongs had already demonstrated, the Liverpool abolitionists

47 Clarkson, Impolicy, p. 44. Clarkson does not say who these complaints were addressed to, or from which port they derived, only that the person was not connected with the law, and that these sixty-three complaints were received over a three-month period.

48 W. Currie, Memoir, pp. 113-14.

49 W. Currie, Memoir, pp. 121-2; Sanderson, “Abolitionists”, p. 209.

50 Sanderson, "Liverpool Abolitionists", p. 209; A. Wilson, Roscoe, p. 130. 
believed that many slave merchants were good, respectable men misled into thinking their business was morally acceptable by virtue of the slave trade's long existence. In addition, Clarkson's research might have made them uncomfortable, as there was a significant difference between abstractly discussing Africans' philosophical or religious rights to freedom and accusing friends and neighbours of endorsing or enacting violence against British men.

\section{Gradual abolition}

Before Clarkson's visit, there is little to suggest that the Liverpool abolitionists had fully considered whether Parliament should vote to gradually or immediately end the slave trade. The Wrongs called for immediate parliamentary intervention in the slave trade, focusing on the inhumanity of the trade, and not the potential economic ramifications of its abolition. Furthermore, Roscoe's correspondence with Barton does not indicate that he wanted anything but a hasty end to the trade. By the close of 1787, however, both Roscoe and Currie had firmly aligned themselves in favour of Parliament gradually ending the slave trade. Clarkson's visit to Liverpool between September and October 1787 appears to have been the catalyst for the Roscoe Circle to endorse gradual abolition.

In late 1787, Roscoe penned a pamphlet in which he argued for gradually restricting the slave trade. A General View of the African Slave Trade defended slave merchants against bearing the brunt of the blame for the slave trade, arguing that the government and society that tolerated and silently acquiesced to the trade also shared in the merchants' criminality. ${ }^{51}$ Roscoe repeated the usual arguments against the slave trade and then introduced some "hints" for how abolition should be achieved. He placed much of the responsibility for ending the slave trade on legislative action taken in the West Indies. Through increased taxation on slave purchases and the institution of certain human rights for slaves in the colonies, combined with a slowly decreasing set number of yearly slave imports, Roscoe believed that abolition could be achieved by the year $1800 .^{52}$ Although the London Committee opposed the idea of gradual abolition, it published the pamphlet in 1788.

\footnotetext{
51 Roscoe, A General View of the African Slave Trade, Demonstrating its Injustice and Impolicy; with Hints Towards a Bill for its Abolition, London, R. Faulder, 1788, p. 12.

52 Roscoe, General View, pp. 32-9.
} 
Roscoe and Currie clearly debated the issue of gradual abolition. As Krawczyk notes, Currie's letter to Wilberforce in December 1787, in which he too argued for gradual abolition, followed the exact same points of reasoning as Roscoe's pamphlet. ${ }^{53}$ In the letter, Currie expressed the expectation that the MP would propose gradual abolition in Parliament as it was "not only the more practicable, but the better scheme". 54 Pre-empting the Dolben Bill, Currie suggested the immediate regulation of the trade: a ban on new vessels entering the slave trade; restriction of ship sizes and number of slaves carried; creation of a "gradually increasing duty" to reduce the number of slaves transported; and encouragement of exports of other African goods. ${ }^{55}$ According to Krawczyk, the echoing messages in Currie's letter and Roscoe's pamphlet served to reinforce each other, although being targeted at different, but related, audiences. ${ }^{56}$

In early 1788 Roscoe pressed the London Committee to consider the benefits of gradual abolition and the consequences of immediate abolition. Barton responded to his friend, explaining that although he agreed with Roscoe's sentiments,

Many of our Committee, however, seem to be of a different opinion, \& shew an unaccountable unwillingness to lend an ear to anything that can be urged in favour of this more moderate and more practicable measure. Nothing short of an entire and immediate abolition will satisfy them, and they have for some time past been buoyed up with a notion that this wod be obtained.

Barton, nonetheless, expected that gradual abolition would eventually prevail. ${ }^{57}$ When a motion for gradual abolition passed the House of Commons in 1792, the London Committee at once resolved that it was not "an adequate Remedy for [the trade's] Injustice and Cruelty". ${ }^{58}$ Up until the moment of casting his vote for abolition in the House of Commons in February 1807, Roscoe also pledged support for compensation for merchants' losses from abolition.

Scholars have put forward various explanations for Currie and Roscoe's sudden interest in gradual abolition. Roscoe's recent biographer Arline Wilson argues that his support for gradualism stemmed from his pragmatism. He believed that gradual abolition would garner the support that immediate and total abolition never could, especially in Liverpool. Gradualism and compensation, therefore, were strategies that would precipitate

\footnotetext{
53 Krawczyk, "Mediating Abolition”, p. 216.

54 W. Currie, Memoir, p. 123.

55 Ibid., p. 124.

${ }^{56}$ Krawczyk, "Mediating Abolition”, p. 217.

${ }^{57}$ Barton to Roscoe, 6 March 1788, LRO 920/ROS/253; Sanderson, “Abolitionists”, pp. 209-11.

${ }^{58}$ London Committee Minutes, 5 April 1792, BL Add MS 21256; Jennings, Business, p. 72.
} 
abolition. ${ }^{59}$ Krawczyk, meanwhile, argues that Currie converted Roscoe to gradualism. As he points out, Roscoe switched from staunch support for immediate abolition to advocating gradualism in under a year. Like Sanderson, Krawczyk believes that the less uncompromising Currie had always favoured gradual abolition, and that his gradualism is perceptible in his preface to The Wrongs of Africa through his effort to "modulate the uncompromising tenor of the poem". Therefore, the close collaborative relationship that existed between the two men, and which Krawczyk believes began with The Wrongs, resulted in Currie exercising a mediating influence on Roscoe. ${ }^{60}$

Neither scholar considers Clarkson as a factor in the Liverpool abolitionists' adoption of a gradualist policy. While no concrete evidence can clarify Roscoe and Currie's exact motivations, the timing suggests that Clarkson's visit played a role in their reassessment of the path to abolition. This idea is supported by Currie's endorsement of gradualism in the very letter in which he criticised Clarkson's actions in Liverpool. It is not implausible that the stir Clarkson caused when visiting the town forced the Liverpool abolitionists to reflect, perhaps properly for the first time, on the real implications of abolition for the town of Liverpool. As will be discussed shortly, the Roscoe Circle were careful not to advertise their position on abolition, meaning that, prior to Clarkson's visit, they had probably had few occasions to seriously discuss abolition outside of their group. So, when Clarkson made abolition a popular topic of conversation, Currie and Roscoe would have been confronted with the other side of the question, voiced by their slave trader friends.

A more complete understanding of why Currie and Roscoe embraced gradualism may be gained by accepting that the three explanations raised here are not mutually exclusive. While it is doubtful that pragmatism alone accounts for their support for gradual abolition, it is nonetheless likely that it was a strong factor in their decision. From what we know of both Currie and Roscoe, it is also quite likely that Currie had a hand in swaying Roscoe towards gradualism. The evidence does not, however, support the idea that Currie was a committed gradualist prior to Clarkson's visit, or that he exercised enough influence over Roscoe to convince him without other factors weighing in. As Krawczyk specifies, they had a collaborative relationship. Furthermore, the evidence does not indicate whether the Roscoe Circle as a whole came to support gradual abolition, or if gradualism was limited to Roscoe and Currie. Indeed, historians apply generalisations to the Roscoe Circle,

\footnotetext{
59 A. Wilson, Roscoe, p. 154.

${ }^{60}$ Krawczyk, "Mediating Abolition", p. 214-17; Sanderson, "Liverpool Abolitionists", p. 204.
} 
when several members demonstrated their commitment to abolition differently from Roscoe and Currie. For example, not all members of the Roscoe Circle demonstrated the same concern regarding maintaining their anonymity.

\section{Anonymity}

Roscoe and Currie demonstrated extreme care in keeping their abolitionism anonymous, yet Rushton and a couple of lesser-known Liverpool abolitionists openly showed their support for the movement. Considerable historical attention has been paid to abolitionist concerns for anonymity in response to real or perceived threats of retaliatory violence, but there is also a connection to be made between anonymity and level of participation. An interesting juxtaposition existed in Liverpool between publicly recognised and invisible abolitionists. Much less is known about the open supporters of abolition in late 1780s Liverpool than about the secretive ones. Furthermore, those willing to have their support for abolition known seemingly participated less actively in the campaign than those who preserved their anonymity. What, then, explains the different attitudes towards anonymity?

Roscoe made it clear from the very start that he wanted his name to remain completely disassociated from his contributions to the abolition campaign. In March 1787, Roscoe arranged for his friend Barton to organise the publication of The Wrongs of Africa in London to prevent anyone from suspecting that he might be the poem's author. Barton's letters to Roscoe reveal the depth of the poet's concern for anonymity, as the Londoner had repeatedly to assure his friend that his name and location would not be let slip. ${ }^{61}$ "Depend upon it", Barton wrote, "I will strictly observe the injunctions that accompany it, and I have also cautioned [the publisher Robert Faulder] against dropping any hints concerning the quarter from whence it comes". ${ }^{62}$ Moreover, for fear that his letters should fall into the wrong hands, Barton always referred to "the poet" and never mentioned Roscoe's name in relation to The Wrongs, even in his private letters to Roscoe. The London Committee's Minute Book also only refers to the "author" of The Wrongs of Africa, never associating the poem with Roscoe's name. ${ }^{63}$

\footnotetext{
${ }^{61}$ See Barton to Roscoe, 7 February 1787, LRO 920/ROS/241 for Barton's first assurance of Roscoe.

62 Barton to Roscoe, 27 March 1787, LRO 920/ROS/243.

${ }^{63}$ London Committee Minutes, 7 June 1787, BL Add MS 21254.
} 
Currie went to even greater lengths than Roscoe to distance his public self from his private abolitionism. Well-known as the most cautious member of the group, Currie implemented ruses to divert suspicions away from him and the other Liverpool abolitionists, in what Krawczyk has termed a "counter-intelligence measure". For example, in 1787 Currie recommended The Wrongs to his friend Lieutenant Graham Moore. To protect Roscoe's anonymity, however, Currie purposefully misdirected Moore by telling him that the poem came from London and that he believed Cowper or Hayley to be the author. $^{64}$ In March 1788, a panicked Currie this time begged Moore's help to draw attention away from him. Rumours of an abolitionist poem jointly composed by Currie and Roscoe had spread, which the Liverpool slave traders, Currie feared, "would impute to the author as an unpardonable offence". Currie therefore wanted the poem "printed in London without delay, that its origin may be traced no higher than the paper in which it appears". ${ }^{65}$ To completely assure his anonymity, Currie instructed his friend not to share the poem's provenance and to show only a re-written transcript of the poem so that Currie's handwriting might not be recognised. ${ }^{66}$

Roscoe and Currie's preoccupation with anonymity sits uncomfortably with the public stance taken by Dannett and Yates against the slave trade in early 1788. That year, Roscoe Circle members Dannett and Yates both preached against the slave trade. ${ }^{67}$ Yates, a Warrington Academy graduate and the pastor of the Kaye Street Presbyterian chapel, famously angered members of his congregation in a sermon against the slave trade that was never published, and in the process earned a reputation as one of the most "disputatious" members of the Roscoe Circle. ${ }^{68}$ Meanwhile, Currie had encouraged the Anglican minister Dannett to publicly respond to Harris' Scriptural Researches. Harris' reaction to Dannett's $A$ Particular Examination of Mr. Harris' Scriptural Researches highlighted the value of Liverpool abolitionists signing their names to anti-slave trade propaganda. Although Harris had

\footnotetext{
${ }^{64}$ Krawczyk, "Mediating Abolition", p. 215.

65 Currie to Moore, 23 March 1788, LRO 920/CUR/108. The poem's original title was “The Negroe's Complaint", but Moore took the liberty of changing the title to "The African" when he had it printed in The World. Currie explained the creative process behind the poem in this letter. See also Moore to Currie, 20 March 1788, LRO 920/CUR/107.

66 Currie to Moore, 16 March 1788, 920/CUR/106.

${ }^{67}$ While Yates is recognized to have belonged to Roscoe's inner circle, Sanderson has questioned Dannett's membership to the Roscoe Circle. Considering the ahistorical nature of the term "Roscoe Circle", and its common loose application to members of Roscoe's entourage, Sanderson is perhaps wrong to so quickly dismiss Dannett's membership to the Circle considering his close abolitionist links to both Roscoe and Currie. In 1788, Currie was familiar enough with Dannett's views on abolition to prompt him to confront Harris and, in 1791, Roscoe and Dannett travelled to London together, where Roscoe intended to accompany Dannett to a meeting of the London Committee. Dannett later partnered with Rushton to help found a Liverpool school for the blind. Sanderson, "Liverpool Abolitionists", p. 213; Littlewood, The Roscoes, pp. 146-47; Howman, “Abolitionism”, p. 283.

${ }_{68}$ Littlewood, The Roscoes, pp. 101, 73; Huddleston, Children's Teeth, p. 368.
} 
elicited four responses by June 1788, including one by the celebrated abolitionist pamphleteer James Ramsay and an anonymous one by Roscoe, Dannett's work irked Harris the most, despite it having been the least well received by the public ${ }^{69}$ Significantly, neither Dannett nor Yates suffered any repercussions for publicising their support for abolition.

It is difficult to gauge exactly what kind of retribution Roscoe and Currie feared by making their abolitionism known. Writing to his uncle in July 1788, Currie admitted to authoring the preface to The Wrongs, but added "this must not be known, for it would play the $\mathrm{d}[\mathrm{e}]$ uce [that is, the devil] with me here". ${ }^{70}$ Clarkson believed that the Liverpool abolitionists justly feared physical reprisals for their views. Witnesses in Liverpool, he said, refused to provide evidence for fear the pro-slavery faction would destroy their houses. ${ }^{71}$ Later, Clarkson discovered their apprehensions were well founded when he received anonymous death threats and was almost pushed off the pier and assaulted by a group of men. Thereafter, Clarkson's travel companion, the abolitionist Alexander Falconbridge, who had already taken to carrying two concealed pistols, insisted on acting as his bodyguard. $^{72}$ A similar plot, Clarkson learned, was devised against the Quaker doctor Jonathan Binns for assisting Clarkson's research. ${ }^{73}$ Sanderson argues that had Clarkson's aggressors truly intended to kill him they would have succeeded, but Oldfield notes that Clarkson took the threat of danger seriously, for the next time he visited Liverpool in 1792, he did so in secret and under cover of darkness. ${ }^{74}$

It is likely that the Liverpool abolitionists did not fear physical violence as much as alienation and loss of income. Indeed, Roscoe, Currie, Rathbone and even Yates all had business ties to slave traders, as well as personal ones. Roscoe's business partners were connected to the slave trade, as would have been many of the Rathbones' trading partners. Currie's success as a local doctor also depended on his good standing in a community that held varied interests in the slave trade. ${ }^{75}$ Littlewood suggests that the Yates would have

\footnotetext{
69 Sanderson, "Liverpool Abolitionists", pp. 213-14.

${ }^{70}$ Currie to George Duncan, 5 July 1788, LRO 920/CUR/109.

71 Clarkson, History, Vol. I, p. 388.

72 Ibid., pp. 388, 409-10.

${ }^{73}$ Littlewood, The Roscoes, pp. 73, 96. According to Littlewood, the harassment Binns endured after his name appeared on the 1788 London Committee list of subscribers caused him to move away from Liverpool, but he does not make clear the evidence upon which he bases this assertion. Huddleston mentions that Binns moved to Ackworth in 1795 , but does not specify retaliatory abuse by slave trade supporters as the cause. Considering that by 1795 the Liverpool abolitionists had been inactive for nearly seven years, Littlewood's claim is unlikely. Huddleston, Children's Teeth, p. 316.

${ }^{74}$ Sanderson, "Liverpool Abolitionists", p. 234n64; Oldfield, Popular Politics, p. 83.

${ }^{75}$ Littlewood, The Roscoes, p. 27; Huddleston, Children's Teeth, p. 330; W. Currie, Memoirs, p. 110.
} 
been concerned about having their secret interest in the slaving firm France, Fletcher and Co revealed and labelled hypocrites. ${ }^{76}$

Sanderson argues that support for abolition did not open the Roscoe Circle up to reprisals of any kind, physical or social. Between the London Committee's list of subscribers, knowledge of the abolitionist Quaker ethic and close friendship and kinship links between Roscoe Circle members and slave trading families Sanderson argues that the Roscoe Circle's support for abolition was an open secret for which none of them suffered any persecution, revealing Liverpool merchants as remarkably tolerant. Roscoe's wife was related to the slave trading Lace family, and both Roscoe and Currie were good friends with William Smyth, whose father had interests in the slave trade, and who was familiar with their views on abolition. Sanderson also questions why Binns should have been singled out for reprisals when he was a much less prominent abolitionist than others in town. ${ }^{77}$ Nonetheless, he concedes that as a small group of dissenters in an Anglican dominated community, they had to be wary not to overly draw attention to their unpopular political views. ${ }^{78}$

If the Roscoe Circle's support for abolition was an open secret, what explains Roscoe and Currie's preoccupation with keeping their abolitionist contributions anonymous? And what explains Roscoe's preparedness to have his name inscribed on the London Committee's list of subscribers when he had already taken so much care to hide his connection to the London Committee? Currie is easier to understand. He attempted to maintain absolute anonymity at all time, even making his donation to the London Committee anonymous. If he did discuss abolition, his fervent support for gradualism and his respect for many of the town's slave traders would have appeased his interlocutors. Roscoe's attitude, however, suggests that he did not mind being recognised as a supporter of abolition, provided nobody knew about his contributions to the campaign. As long as Roscoe and his friends appeared to merely agree with the abolition movement, without noticeably contributing to its advancement, the town's slaving interests would leave them in relative peace. By carefully displaying only "passive" support for the abolition movement, the Liverpool abolitionists gained some social acceptance of their views.

Not wanting to appear actively involved in the campaign explains why the Liverpool abolitionists rarely tried to do more than contribute via anonymous writings. In

\footnotetext{
76 Littlewood, The Roscoes, p. 27.

77 Sanderson, "Liverpool Abolitionists", p. 216.

78 Sanderson, "Liverpool Abolitionists", p. 217. More recently, Howman notes that caution was warranted, as Liverpool was prone to sudden and violent outbreaks of social unrest over political issues, Howman, “Abolitionism", p. 279.
} 
December 1787, Manchester abolitionists formed a satellite Committee, and in January 1788 Barton wrote to Roscoe on behalf of the London Committee inquiring into the possibility of Roscoe forming one in Liverpool. The London abolitionists deemed Roscoe the "most suitable person [...] to promote such a measure", nevertheless Barton requested Roscoe suggest another should he think it "not prudent to engage in this undertaking". 79 Roscoe's response was immediate. There is no record of his refusal, but according to Barton it left the London abolitionists "fully convinced of the impropriety of entertaining any further thought of endeavouring to form a Committee on the African business in Liverpool". ${ }^{80}$ In addition to not creating a formal abolition society in Liverpool, they never organised an abolitionist petition, nor volunteered to appear as witnesses on behalf of abolition in Parliament.

\section{The Roscoe-Barton relationship}

Historians underestimate the impact of Roscoe's friendship with Barton on the Roscoe Circle's involvement in the abolition campaign in 1787 and 1788. Even Kevin Littlewood, the Roscoes' latest biographer, who examines the Roscoe-Barton correspondence in detail, fails to fully appreciate the determining influence Barton had on the level of Liverpool participation in the abolition movement. Through their personal relationship, Roscoe and Barton linked the London and Liverpool abolitionists. Barton kept the Liverpudlians up to date on the development of the campaign, and Roscoe provided the London Committee with confidential information on the anti-abolition activities of the Liverpool slaving interest. Furthermore, to Roscoe, Barton acted as an agent and a creative partner. Their collaboration in 1787 and 1788 formed the corner stone on which Liverpool abolitionism rested in these years.

The administrative support Barton lent Roscoe is well attested in their correspondence. Barton liaised between Roscoe and the London Committee, supplying the Committee with copies of Roscoe's works, transmitting Roscoe's information on Liverpool anti-abolitionism, and relaying the Committee's thanks and praises back to Roscoe. On

\footnotetext{
${ }^{79}$ Barton to Roscoe, 21 January 1787 [1788], LRO 920/ROS/239. Barton misdated his letters of 21 January and 7 February 1788 to 1787 . This has led to some confusion in historians' understanding of events. The mistake is confirmed by notes made in pencil in the referencing catalogue at the Liverpool Record Office, and on the Barton Family Website:

http://bartonhistory.wikispaces.com/*John+Barton+the+Elder+Correspondence, accessed 4 June 2013. Notably, neither Sanderson nor Littlewood noticed the incorrect dates. Sanderson, "Liverpool Abolitionists", p. 212; Littlewood, The Roscoes, p. 84.

${ }^{80}$ Barton to Roscoe, 7 February 1787 [1788], LRO 920/ROS/241.
} 
another level, Barton acted as Roscoe's literary agent in London. In addition to organising the publication of The Wrongs of Africa in early 1787, Barton oversaw the editing process, arranged for the poem's advertisement in London papers, and, later in the year, pressed Roscoe to finish the poem's second part. ${ }^{81}$ The evidence suggests that, for the most part, Barton's assistance to Roscoe was not officially sanctioned by the London Committee, with Barton only informing his London colleagues of Roscoe's contributions once they received publication. For instance, Barton's help with The Wrongs predated the London Committee's formation on 22 May 1787, but he first appears to have informed them of the poem when he donated its proceeds on Roscoe's behalf on 7 June. Barton's choice of publisher further highlights the Committee's lack of involvement. Barton commissioned his brother-in-law, the publisher Robert Faulder, rather than the Quaker bookseller James Phillips, long-term abolitionist, Committee founding member, and leading publisher of anti-slavery publications since $1783{ }^{82}$

The correspondence reveals Barton helped Roscoe creatively as well as administratively. Scholars, such as Krawczyk, have highlighted the creative partnership that existed between Roscoe and Currie, but Barton's letters demonstrate that a similar partnership existed between him and Roscoe. Roscoe deferred to Barton on how best to help the abolition movement, and Barton gave Roscoe his frank opinion on the merits of his writing. When Roscoe sent Barton the Wrongs, he also included an abolitionist Sonnet. In no uncertain terms Barton informed Roscoe that the Sonnet should "be either suppressed or altered". Barton believed that the Sonnet was unjustifiably politically divisive which could make it injurious to abolition. If Roscoe were to rewrite the Sonnet, Barton suggested that he include religious as well as philosophical arguments, and that he praise Pitt, in order hopefully to bias the Prime Minister in abolition's favour. Roscoe appears to have taken Barton's advice and suppressed the Sonnet. ${ }^{83}$ In 1788, Roscoe's anonymous response to Harris's Scriptural Researches took the form of four letters from the author to a "friend", the friend being Barton. ${ }^{84}$

Barton also might have been responsible for negatively influencing the Liverpool abolitionists' estimation of Clarkson. Before Clarkson's arrival in Liverpool, Barton wrote

\footnotetext{
81 Barton-Roscoe correspondence, March-September 1787, LRO 920/ROS/243-248.

82 E. Wilson, Clarkson, p. 13; http://bartonhistory.wikispaces.com/Famous+connections, accessed 4 June 2013.

83 Barton to Roscoe, 27 March 1787, LRO 920/ROS/243; Sanderson, “Liverpool Abolitionists", pp. 212, $234 n 72$.

${ }^{84}$ William Roscoe, A Scriptural Refutation of a Pamphlet lately published by the Rev. Raymond Harris entitled, "Scriptural Researches on the Licitness of the Slave Trade", in Four Letters from the Author to a Friend, London, 1788; Littlewood, The Roscoes, p. 104.
} 
to Roscoe requesting him to keep a close eye on Clarkson. Although not much younger than Roscoe, Barton and Currie, the terms used in reference to Clarkson imply a certain condescension. Barton informed Roscoe that although Clarkson's "zeal and activity are wonderful" he might "at times be deficient in caution and prudence". He also questioned Clarkson's judgement, asking Roscoe to give him his opinion on Mr. Falconbridge, questioning whether Falconbridge was "really a man of sense and integrity". 85 A similar air of superiority is present in Currie's letter to Wilberforce condemning Clarkson's actions, which he ends with by expressing his certainty at Clarkson's "purity" of intentions. ${ }^{86}$ Thus, it is quite possible that Barton's letter helped to undermine Clarkson's position and authority with the Liverpool abolitionists before he even arrived in the town.

Historians have failed to connect Barton's death in April 1789 with the cessation of the Roscoe Circle's participation in the abolition movement. Studies of Liverpool abolitionism unanimously attribute the end of the Roscoe Circle's abolitionist contributions to the anti-Jacobin era of repression that followed the French Revolution, and which forced the Literary Society to stop meeting in 1793. The Roscoe Circle, however, ceased making significant contributions to the abolition campaign by the start of 1789. Roscoe had been the most actively involved Liverpudlian in the abolition movement, but withdrew after Barton's death. Had the Liverpool abolitionists' connection to the London Committee been rooted in more than this friendship, such as in a broader Quaker network, Liverpool participation might have been sustained after Barton's death. As it was, the only other significant link between the Roscoe Circle and the London Committee was the one that developed between Rathbone III and Clarkson. Rathbone also died in 1789.

\section{Conclusion}

The Roscoe Circle's aims regarding abolition differed fundamentally from those of the London Abolition Committee. Of course, all abolitionists sought to end the slave trade, but the Liverpool abolitionists diverged from their London counterparts in their approach and strategy. The deep-rooted social and economic ties that connected the Roscoe Circle to the Liverpool slaving interest, and to the town in general, informed their position on

\footnotetext{
${ }^{85}$ Barton to Roscoe, 13 August 1787, LRO 920/ROS/247; Oldfield, Popular Politics, p. 79; A. Wilson, Roscoe, p. 129.

86 W. Currie, Memoir, p. 122.
} 
abolition. Importantly, this position directed how the Roscoe Circle organised their support for abolition.

Since the Roscoe Circle never formed an official abolition society, the Liverpool abolitionists never formally defined their aims or developed an official relationship with the London Committee. Instead, the Roscoe Circle's connection to the abolition movement relied on personal relationships, and was severed by Barton and Rathbone's deaths in 1789. By not publicising their abolitionism, moreover, they limited their role in the movement. A formal society, as the London Committee showed, permitted the creation of an organisational infrastructure for collecting evidence, distributing information and soliciting funds, thus enabling the movement's growth. The Roscoe Circle, however, was a decidedly closed group, intent on keeping the depth of their abolitionism a secret, and rarely targeted local attitudes to the slave trade. The group's insular attitude prevented the growth and strengthening of Liverpool abolitionism, which, combined with its already weak foundations, precipitated the disintegration of organised abolitionist activity in Liverpool in 1789. 


\section{CHAPTER THREE}

\section{REJECTING THE SLAVE TRADE, 1796-1807}

In 1985, Seymour Drescher argued that between 1788 and 1807 Liverpool experienced a slow cultural transformation that gradually altered Liverpudlian attitudes towards the slave trade. Drescher's "The Slaving Capital of the World: Liverpool and National Opinion in the Age of Abolition" is, to date, the most significant study of Liverpool abolitionism since Sanderson's work in the 1970s. ${ }^{1}$ Stepping away from the Roscoe Circle, whose activities had subsided by mid-1788, Drescher examined local descriptions of the slave trade in Liverpool guidebooks and other publications targeted at an outside market to trace changing cultural responses to abolition. He found that, culturally isolated for most of the eighteenth century, Liverpool sought to realign with the broader national culture by promoting the arts and sciences in the late 1790s; as the town sought to strengthen national ties and attract visitors, the slave trade increasingly became a source of unease and embarrassment to many Liverpudlians, leading to their gradual rejection of the slave trade.

Drescher importantly demonstrated that Liverpudlians did not unanimously support the slave trade's continuance when Parliament voted to abolish it in 1807. Prior to Drescher's study, historians of Liverpool abolitionism focused on the Roscoe Circle, thereby limiting the scope of their studies to the actions of a few individuals at the very start of the abolition campaign. Drescher's analysis of Liverpool guidebooks, newspapers, and histories, however, shed new light on the wider shifts occurring in popular attitudes towards the slave trade within Liverpool throughout the twenty-year period. Although expressed in a short article, the strength of Drescher's argument derives from his succinctly placing Liverpool's "gradual adaptation to the national outlook" in the social context of Liverpool's isolation from and re-convergence with British culture in the period, and its impact on Liverpool's construction of self-identity.

\footnotetext{
${ }^{1}$ Seymour Drescher, "The Slaving Capital of the World: Liverpool and National Opinion in the Age of Abolition", Slavery and Abolition, 9:2, 1988, pp.128-143. Based on his 1985 paper of the same title presented at the International conference on the slave trade in Nantes, France.
} 
This chapter analyses growing popular support for abolition in Liverpool in the period 1796-1807. Building upon Drescher's study, this chapter re-examines the different editions of the Liverpool guidebooks, published between 1796 and 1805, to more precisely map Liverpool's changing relationship with the slave trade. In 1805, the publication of two anti-slave trade letters in the Liverpool Chronicle further marked the increasing social acceptability of anti-slave trade thought in Liverpool. Moving away from Drescher, however, this chapter then argues that Roscoe's parliamentary election in December 1806, his vote for abolition in the Commons, and his dramatic exit from office in May 1807 unquestionably demonstrate that abolition had lost its prior contentiousness in Liverpool by 1806. The current historical consensus is that Roscoe angered Liverpudlians by voting for abolition, thereby revealing that his election the previous year did not demonstrate a sea change in local support of the slave trade. This chapter argues that historians have overlooked indications that the backlash Roscoe faced stemmed less from his vote for abolition than for his support of other controversial policies, such as Catholic emancipation.

Liverpool guidebooks, polite culture and defending the slave trade

The publication in 1796 of Liverpool's first guidebook marked Liverpool's rise as a tourist destination. Liverpool surgeon and scholar William Moss produced The Liverpool Guide for local booksellers Crane and Jones of Castle Street, and the London firm Vernor and Hood sold it in the capital. ${ }^{2}$ A town guide had become necessary, Moss explained, because in addition to attracting a "great number" of business visitors, Liverpool had recently become a "resort also of strangers of all descriptions, for the purpose of health and amusement". ${ }^{3}$ The inclusion of a five-page "Sketch of the Town and Trade of Liverpool" in the 1796 edition of Gore's Liverpool Directory supports Moss's report of increased tourism, and highlights Liverpool efforts to promote the town as a holiday destination. ${ }^{4}$ Between 1796 and 1801, Moss and William Jones published four

\footnotetext{
2 William Moss, The Liverpool Guide, $1^{\text {st }}$ ed., Liverpool, 1796; David Brazendale, author of the 2007 annotated reprint of the Liverpool Guide, identifies Moss as the author of An Essay on the Management and Nursing of Children, Liverpool, 1781, and A Familiar Medical Survey of Liverpool, Liverpool, 1784. David Brazendale, Georgian Liverpool: A Guide to the Town in 1797, Lancaster, 2007, pp. xi-xii.

${ }^{3}$ Moss, Liverpool Guide, 1796, pp. 1-2.

${ }^{4}$ John Gore, Gore's Liverpool Directory, Liverpool, 1796, pp. 193-7. Unfortunately, to my knowledge, there are no existing copies of the 1791 to 1795 editions of Gore's Directory making it impossible to know whether the "Sketch" first appeared in 1796, or before. It is not included in the 1790 edition.
} 
editions of The Liverpool Guide, demonstrating the guide's popularity and the frequent need for revision due to an ever-changing townscape. ${ }^{5}$ Moss died in 1802, and in 1805 Jones commissioned a new guide, The Picture of Liverpool. ${ }^{6}$ That the new guide repeated large sections of Moss's work verbatim, may suggest that Jones was also its anonymous author.

Moss's first guide addressed the contemporary concern that Liverpool's commercial focus hindered the town's cultural development. He excused Liverpool's lack of artistic and scientific institutions, thus answering historian James Wallace's disparaging study of Liverpool published the previous year. ${ }^{7}$ According to Wallace, Liverpudlian preoccupation with business had resulted in a town void of culture: "Arts and sciences are inimical to the spot, absorbed in the nautical vortex, the only pursuit of the inhabitants is COMMERCE". ${ }^{8}$ Moss agreed that the commercial mind had little time and little predisposition to pursue the sciences and polite arts, and was therefore ill equipped to promote such disciplines. ${ }^{9}$ He described, instead, an "alternative culture", distinct to a commercial town such as Liverpool, one favouring sociability, charity and outdoor activities for the pursuit of amusement and the promotion of health. ${ }^{10}$

Recent scholarship addressing Liverpool culture has shown that notions of what constituted cultural pursuits changed over the course of the eighteenth century. For most of the century Moss's definition of culture, that emphasised sociability, entertainment and exercise, prevailed and was reflected in the construction of edifices such as the Theatre Royal, the Music Hall, Ranelagh Gardens and several Walks. By the last two decades of the century, however, many public leisure spaces had been lost, and visits to the theatre and Music Hall, although still popular, were increasingly devalued as cultural pursuits. Culture had acquired an intellectual dimension, and had become associated with education, learning and cultivating the fine arts. ${ }^{11}$ But, until the late 1790s Liverpool struggled to sustain learned societies, usually formed by local dissenters,

\footnotetext{
5 The subsequent editions of The Liverpool Guide were published in 1797, 1799 and 1801. Crane had left the business by the time the 1797 edition was printed.

6 The Picture of Liverpool; or Stranger's Guide, Liverpool, 1805; Brazendale, Georgian Liverpool, xii.

7 Moss, Liverpool Guide, 1796, pp. 95-6; James Wallace, A General and Descriptive History of the Ancient and Present State of the Town of Liverpool, Liverpool, 1795. In her 1997 study of urban histories Rosemary Sweet states that the first edition of Moss's guide was published in 1793, and that Wallace may have written in reaction to Moss's work. I have not, however, found another report of a 1793 edition of The Liverpool Guide, and the 1796 edition indicates that it is the first, with Moss describing it "a very hasty and a novel production". Rosemary Sweet, The Writings of Urban Histories in Eighteenth-century England, Oxford, 1997, p. 130; Moss, Liverpool Guide, 1796, preface.

8 Wallace, Descriptive History, p. 283.

${ }^{9}$ Moss, Liverpool Guide, 1796, pp. 95-6; Jon Stobart, "Culture”, p. 476.

${ }^{10}$ Sweet, Urban Histories, p. 130.

11 Longmore, "Civic Liverpool”, pp. 474-77.
} 
as Liverpudlians secured higher social and cultural status from visits to cultural institutions in the capital and leisure facilities in resort towns rather than from investment in local facilities. ${ }^{12}$

By 1796, when Moss published his first guide, the Common Council had shown a new interest in reforming Liverpool's cultural identity and improving the town's image in the country at large. According to Jon Stobart, even as councillors continued to defend the slave trade they sought to distance themselves from their past by "show[ing] themselves as more sensitive to the civilising influence of cultural life than previously". They pursued cultural redefinition by supporting and supervising local cultural projects, often initiated by the Roscoe Circle. In addition, they tried to rehabilitate their image by portraying themselves as moral, charitable and humanitarian. For example, in listing the numerous charities supported by the Council and local elites, Moss's guide served to counter the prevailing view of Liverpudlians as inhuman and immoral for their support of the slave trade. ${ }^{13}$

Targeting a largely pro-abolitionist market, Moss was at pains to justify the slave trade whilst not alienating his reader. As Drescher notes, Moss favoured a moral discussion of the slave trade rather than summarising its history. ${ }^{14}$ Therefore, after briefly indicating the trade's great commercial value to Liverpool, he immediately conceded that "As a simple moral question, considered in the abstract, [the slave trade] can meet with no countenance". Yet, he continued, "In a political point of view, every thing favours it". ${ }^{15}$ Avoiding the issues raised by abolitionists, such as slave kidnappings and maltreatment on the Middle Passage, Moss's principle argument held that the slave trade must continue for the good of African society. In overtly racist tones, Moss argued that British abolition of the slave trade would force a violent revolution upon an unprepared slavery-based African society. Abolitionists, although morally justified, needed to temper their zeal, for abolition could only be achieved through a lengthy process of enlightening the savage Africans. ${ }^{16}$

A comparative study of the first three editions of The Liverpool Guide indicates that between 1796 and 1799 the British public maintained pressure on Liverpool to abandon the slave trade, despite abolition's continued lack of success in Parliament. Each year, Wilberforce motioned the Commons to abolish the slave trade, only to be

\footnotetext{
12 Stobart, "Culture", pp. 475-76.

13 Ibid., p. 480.

${ }^{14}$ Drescher, "Slaving Capital", p.136.

15 Moss, Liverpool Guide, 1796, pp. 99-100.

16 Moss, Liverpool Guide, 1796, pp. 100-4; Drescher, "Slaving Capital”, pp. 136-37.
} 
defeated by often-narrow margins. ${ }^{17}$ Yet, each new edition of The Liverpool Guide contained an updated section on the slave trade that attempted ever more forcefully to justify its continuance. By the third edition, published in 1799, Moss complained that "much illiberal and ungenerous reflection has indiscriminately been cast upon [Liverpool]" because of its role in the slave trade. He argued that the notoriety was unwarranted since comparatively few Liverpool merchants participated in the trade; numerous non-resident slave traders, such as merchants from Bristol, Lancaster or London, based agents in Liverpool to hire sailors and outfit ships. ${ }^{18}$ The timing of Moss's renewed and desperate attempts to convince his readers against abolition indicates that abolition remained a popular cause, to which Moss sensed his readers were committed, despite the London Abolition Committee's gradual withdrawal from the campaign in the mid-1790s. ${ }^{19}$

In the fourth edition of the guide, published in 1801, Moss displayed new composure and self-assurance in justifying the slave trade's continuance. With the abolitionist sympathies of his readership still in mind, he pronounced that reason had prevailed over fanaticism, indicating that even the previously enthusiastic abolitionist Prime Minister William Pitt had recently advocated caution over hasty abolition. ${ }^{20}$ Moss even questioned the slave trade's supposed immorality; recent publications having describing the brutal and savage state of African society, Moss asked who "could not contemplate a British colony in the West Indies, as an asylum for these poor wretches, rather to be wished for than reprobated?"21 One can attribute Moss's renewed confidence in the slave trade's legitimacy to recent fluctuations in slave trading and abolitionist activities: the British slave trade peaked in 1798-1799, immediately followed in $1800-1802$ by the lowest point of abolitionist activity. ${ }^{22}$ Notably, in 1800 , for the first time in twelve years, Wilberforce made no motion of abolition in Parliament. He kept quiet again in 1801, and that same year, Pitt resigned. ${ }^{23}$

Despite The Liverpool Guide's sustained justification of continued slave trading between 1796 and 1801, it nonetheless represents a first step in Liverpool's growing rejection of the slave trade. As Drescher explains, Moss began the process of distancing

${ }^{17}$ In 1796 abolition was defeated by 74 votes to 70; in 1797 by 82 to 74 ; in 1798 by 87 to 83 ; and in 1799 by 84 to 54. See Anstey, Slave Trade, pp. 280-81, 322.

${ }_{18}$ Moss, Liverpool Guide, $3^{\text {rd }}$ ed., 1799, p. 116.

19 The Committee had suspended regular meetings in 1794, and stopped meeting altogether in 1797. Jennings, Business, pp. 85, 93.

20 Moss, Liverpool Guide, $4^{\text {th }}$ ed., 1801, pp. 127-31.

${ }^{21}$ Ibid., pp. 131-32.

${ }^{22}$ Drescher, Econocide: British Slavery in the Era of Abolition, Pittsburgh, 1977, pp. 120-21.

23 Anstey, Slave Trade, pp. 321, 334. 
Liverpool from the slave trade. He acknowledged the trade's importance to Liverpool commerce but depicted it simply as a branch of trade, without portraying it as a distinctive feature of the town or linking it to the port's commercial development. The slave trade did not define Liverpool's overseas commerce; neither did it define Liverpudlian identity. Moss stressed that very few local merchant houses engaged in the trade. In highlighting that Liverpool's port operated for nationwide ship-owners and merchants, Moss realigned Liverpool interests with British interests as a whole. Britain viewed the slave trade as occurring on its periphery: Liverpool. Through The Liverpool Guide, Liverpool now relegated the slave trade to its own periphery. ${ }^{24}$

By 1805, when a new Liverpool guidebook entered the market, Liverpool had transformed its cultural identity. Unlike Moss in 1796, the anonymous author of The Picture of Liverpool had no need to make excuses for Liverpool's lack of artistic and scientific institutions. ${ }^{25}$ A new cultural renaissance had been achieved through the cooperation between local dissenters, led by the Roscoe Circle, and the Common Council. ${ }^{26}$ Liverpool now boasted the Athenaeum, the Botanic Gardens, Bullock's Museum and show rooms, as well as numerous libraries and coffee houses, which the new guide listed without apology or comparison to London counterparts. Membership to the Athenaeum, recently described as Liverpool's "most enduring" cultural institution, quickly became a status symbol, and in 1807, Boston modelled its own Athenaeum after the Liverpool original, thereby cementing Liverpool's status as cultural role model. Roscoe's role in the founding of both the Athenaeum and the Botanic Gardens helped to propel him to cultural eminence. ${ }^{27}$

Whereas Moss disassociated Liverpool from the slave trade at an economic and, to an extent, at a social level, The Picture of Liverpool added a moral distance. By mid-1804, the London Committee had reconvened and Wilberforce's Abolition Bill had succeeded in the House of Commons. ${ }^{28}$ The following year, the author of Liverpool's new guide categorically condemned the slave trade. Slave trading was unquestionably immoral, and those engaged in it, now limited "chiefly to three or four houses", alone could defend their conduct. The guide then denounced the "unfounded" and "illiberal" but widespread view held in Britain that the slave trade had "the unqualified sanction" of all

\footnotetext{
24 Drescher, "Slaving Capital", p. 137.

25 The Picture of Liverpool; or Stranger's Guide, Liverpool, 1805.

${ }^{26}$ Stobart, "Culture", pp. 480-81.

27 A. Wilson, Roscoe, pp. 72-5.

28 Anstey, Slave Trade, p. 344; Jennings, Business, pp. 100-1. The Commons set abolition to come into effect from 1 January 1805, but the motion was postponed when it reached the Lords.
} 
Liverpool residents. The town, in fact, had produced many "friends of the hapless Africans", who:

have remonstrated in public and in private, through the medium of the pulpit and the press. They have called to their aid the powers of argument, the charms of poetry and the graces of oratory, in doing which they have acquitted themselves of what they conceived to be an imperious duty, to their own consciences, their country and their God. ${ }^{29}$

Liverpool abolitionists were no longer traitors who threatened the economy but "a source of civic redemption" and the slaving faction was relegated to a very small proportion of the population. In Drescher's words, The Picture of Liverpool demonstrated that "Liverpool would no longer allow itself to be made the moral mediator of the slave trade". 30

On the surface The Picture of Liverpool indicates that abolitionism had made considerable inroads within Liverpool society by 1805, yet one can question the reliability of this town guide's "picture" of Liverpool. As Rosemary Sweet notes, "the image of a town and the identity created in a text were not just a manifestation of civic tradition and pride, but they were also the product of hyperbole written to draw the travellers to the town". ${ }^{31}$ It is not surprising that the guide does not name these "many" abolitionists, but one can question whether their views were widely known, and wonder how many is many? From our knowledge of the Roscoe Circle's activities we can surmise that the guide refers to its abolitionists members. Would contemporaries have had sufficient knowledge to deduce the same? More importantly, why did the guide's author choose to remain anonymous? Was there still a stigma attached to abolitionists in Liverpool? Perhaps his anonymity had nothing to do with abolitionist debates. Ultimately, The Picture of Liverpool illustrates the obscurity and imprecision that pervades sources of Liverpool abolitionism in this period. The "Argus Letters", published in the Liverpool Chronicle in early 1805, are equally problematic; yet they too add to our understanding of growing abolitionist support in Liverpool in the early nineteenth century.

\footnotetext{
29 Picture of Liverpool, pp. 147-48.

${ }^{30}$ Drescher, "Slaving Capital", p. 138.

31 Sweet, Urban Histories, p. 102.
} 
The Liverpool Chronicle

In February 1805, in two letters to the editor of the Liverpool Chronicle, a correspondent writing under the pseudonym "Argus" testified to a large but invisible community of abolition supporters in Liverpool. These letters, mentioned briefly by Drescher, echo the latest guide-writer's frustration that the slave trade continued to determine Liverpool's reputation. Likewise the letters argued that local abolition supporters outnumbered slave trade supporters. ${ }^{32}$ An abolitionist petition from Liverpool, Argus believed, would prove that the town's "friends of justice and humanity [were] sufficiently numerous to defeat the corrupt purposes of individuals blinded to the perception of truth, and opposed to the practices of benevolence by their pecuniary interests". ${ }^{33} \mathrm{~A}$ close examination of the 198 existing issues of the infrequently cited Liverpool Chronicle, published between January 1804 and December 1807, shows that these letters represented the first time that the paper gave voice to anti-slave trade opinion. It was also the first time that the paper's editor intimated his own disapproval of the traffic. Further research reveals that William Jones, publisher of the guidebooks, was the newspaper's publisher and owner, and it is reasonable to surmise that he was also its editor. ${ }^{34}$

In the letters, printed on 20 and 27 February 1805, Argus complained that the outside world could still stigmatise all Liverpudlians as slave trade supporters because the town's abolitionists remained unacknowledged and unrepresented both in and out of town. To Argus, the town's representatives, from the Mayor through to the Members of Parliament and the Common Council, encouraged the view that the town wholly supported maintaining the slave trade. For instance, by having recently chaired a meeting of African Merchants, Argus believed that the Mayor (who he does not refer to by name), as town representative, had unfairly presented the town as unanimously pro-slave trade. ${ }^{35}$ In addition, the Council had spent thousands of pounds of town funds over the

32 "To the Editor", Liverpool Chronicle, 20 February 1805; "Slave Trade Letter II", Liverpool Chronicle, 27 February 1805; Drescher, "Slaving Capital", pp. 137-38. Also referenced in Drescher, Capitalism and Antislavery, p. 211 n20.

33 “Slave Trade Letter II", Liv. Chron., 27 February 1805.

34 Woodward's New Liverpool Directory, Liverpool, 1804, p. 84; Gore's General Directory, Liverpool, 1807, p.146; Littlewood, The Roscoes, p. $327 n 20$. Hannah Barker explains that it was common for owners of provincial newspapers to assume the roles of editor, lead writer, manager and reporter, with only the most successful owners being able to take a back seat by employing a separate editor. Hannah Barker, Newspapers, Politics, and English Society 1695-1855, Harlow, 2000, pp. 96, 99.

35 "Letter to the Editor", Liv. Chron., 20 February 1805. An examination of several Liverpool directories confirms that William Harper (1749-1815), mayor from 1804 to 1805, is the same William Harper listed by David Pope as one of Liverpool's leading slave trading merchants. According to the Slave Trade Database (http://www.slavevoyages.org), William Harper invested in 66 slaving ventures between 1784 and 1807. The 
years to fight the abolitionists, and petitions sent to parliament were frequently presented as "from the Merchants, Traders and OTHER INHABITANTS of the town of Liverpool'. ${ }^{36}$ One of the town's MPs had even told the House of Commons that "he was deputed by the Corporation of Liverpool, and ten thousand of its inbabitants to oppose the abolition bill in all its stages" to which Argus retorted that the gentleman in question had "never received so respectable a sanction". 37

Despite Argus's grievance against local officials, he indicated that support for the slave trade within Liverpool's Common Council had been waning. He revealed that one reasonably prominent council member had spoken out against allotting further funds to defending the slave trade. This gentleman had finally had the "confidence" to proclaim that "no further assistance could be afforded from the town's purse, and that if the trade were worth defending, it must, in future, be done by the African merchants themselves". 38 Supposing Argus's statement correct, the process of social and moral distancing had begun to extend to Liverpool's elite merchant community. ${ }^{39}$

The Argus letters, as with The Picture of Liverpool, do not reveal sources or name individuals, making an interpretation of the already unclear indicators of Liverpool abolitionism that much harder. Whether or not Argus was a Roscoe Circle member has bearing on what types of people he placed among the "large proportion" of Liverpudlians to hold the slave trade in "just abhorrence". ${ }^{40}$ Certainly the author's choice of pseudonym suggests classical learning; Argus was a hundred-eyed giant watchman from Greek myth. Liverpool's Argus claimed his situation in life was "obscure", but he joined a meeting of African merchants, attended by fifty or so people. If we consider the term "obscure" an oblique reference to blindness, we might imagine Argus as Rushton, a man both well read and vocal in the condemnation of the slave trade. Unfortunately, we simply cannot know who Argus was. Moreover, it is impossible to deduce the Liverpudlians Argus said abhorred the slave trade. Were they middlingclass dissenters? Could they have been sailors? Were they from different societal ranks?

Universal British Directory of Trade, Commerce, and Manufacture, London, 1794; Gore's General Directory, Liverpool, 1800, 1803; Woodward's New Liverpool Directory, Liverpool, 1804; Pope, "Wealth", p. 199.

36 "Slave Trade Letter II", Liv. Chron., 27 February 1805. For example, on Friday 23 January 1807 the Duke of Clarence presented three anti-abolition petitions from Liverpool to the House of Lords: "one from certain merchants, traders, and others, inhabitants of the town of Liverpool - one from the Mayor, Aldermen, and Common Council of Liverpool, as Trustees for the Wet Docks formed at that port - and one from the Mayor, Aldermen and Corporation of Liverpool in Council Assembled". See "House of Lords", Liverpool Chronicle, 28 January 1807.

37 “Slave Trade Letter II”, Liv. Chron., 27 February 1805; Drescher, “Slaving Capital”, p. 138.

38 “Slave Trade Letter II", Liv. Chron., 27 February 1805.

${ }^{39}$ Drescher, "Slaving Capital", p. 138.

40 "To the Editor", Liv. Chron., 20 February 1805. 
Could they have really equalled in number all inhabitants who did not directly profit from the slave trade?

Argus's use of a pseudonym and lack of specificity in discussing Liverpool's abolitionists also affects our estimation of the social acceptability of abolitionism in the Liverpool of 1805. Argus called for an abolitionist meeting and the creation of a petition. He believed that the local abolitionist community was sufficiently large that a petition would have an impact on the national abolitionist debate. Abolitionist sympathisers must have been known to each other. Abolition must have been discussed. And, if abolitionism existed on the scale that he indicated, supporters surely would have been widely recognised as such, for they would have had security in numbers, and no need to hide their views. Yet there is no evidence to suggest that Argus's meeting or petition ever materialised. It was customary to use a pseudonym when writing to a newspaper, which means that we have no way of knowing how much importance Argus attached to preserving his anonymity. We do know though, that he did not make the arrangements for a meeting in his letters, or subsequently through the Liverpool Chronicle.

On 6 March 1805, the Liverpool Chronicle published a pro-slaving response to Argus. To modern readers, Jonathan Slang's long and confused racist tirade in defence of the slave trade is almost comical. ${ }^{41}$ His frequently nonsensical arguments stemmed from an ardent belief that profit justified the slave trade, even if only a few select merchants profited from it. His warning to the editor against publishing additional abolitionist material exemplifies his attitude: publishing letters such as Argus's “may disturb the internal peace of those, who had rather ruminate on the profits, than on the sufferings which the Slave Trade produces." Good business was Slang's guiding principle: the slave trade was good business for Liverpool, and keeping slave traders happy was good business for the Liverpool Chronicle. Maintaining the wealth and status of African merchants, then, outweighed humanitarian concerns for enslaved Africans.

In the same issue, the editor addressed Argus's letters and, despite Slang's warning, showed definite abolitionist sympathies. In a short statement, he commented that he hoped the letters would be "sufficient to demonstrate this important fact, that in this town there are individuals, (we trust not few in number), who as heartily detest the Slave Trade, as can be found any where out of it". He considered it his duty to "evince that point", and he added his own criticism to Argus's: Liverpool's MP was wrong to

41 "To the Editor", Liverpool Chronicle, 6 March 1805. "Jonathan Slang" is most likely a pseudonym, as there are no men of this name listed in Woodward's New Liverpool Directory of 1804, or Gore's General Directory of 1805 or 1807. 
state in Parliament that the town's affluence and prosperity depended on the continuance of the slave trade. Such a comment, he argued, was "a mere gratuitous assumption, unsupported by any evidence, and resting its claim to credibility, solely on the asserter's confidence; an assertion which nothing would be easier than to refute". Having confirmed the presence of strong abolitionist sentiment in Liverpool, and denied the slave trade's importance to Liverpool, the editor explained that he would print no more letters on the topic until he could see "some probability of good" being done by the debate. ${ }^{42}$

The editor of the Liverpool Chronicle demonstrated astute business acumen in appearing to toe the middle line on the issue of the slave trade. Although he refused to let the Liverpool Chronicle act as a venue for a prolonged debate of abolition, and published both pro- and anti-abolition viewpoints, he skilfully balanced the letters to favour abolition. He printed two abolitionist letters in consecutive issues and ended the debate after printing one ineffective pro-slaver's response. The Argus letters would surely have provoked a number of responses defending the slave trade, yet the editor printed one that did little to help its cause. In addition, when the editor entered the discussion, he ignored Slang's arguments but reinforced Argus's. While it is likely that the editor was wary of alienating his pro-slave trade readership by encouraging the abolition debate, it is perhaps also possible that he wanted to avoid printing defences of the slave trade that were not only morally reprehensible but that also had the potential to help abolitionists' opponents.

Despite the editor's apparent sympathies with the abolition movement, it would take the Liverpool Chronicle almost two years to finally espouse a policy of open abolitionist support. In January 1807, the editor republished an open letter to the Duke of Clarence, first published in the London paper the Independent Whig. In uncommon anti-racist terms for the time, the letter's author sought at length to convince the Duke of the immorality of the slave system. The Liverpool Chronicle's editors explained the letter's inclusion in the issue, stating "the subject being of great importance, especially at the present time, we hope it will prove acceptable to our readers." ${ }^{43}$ In February, the editors announced their pleasure to find that abolition was not likely to be dropped in the House of Commons, and after the Abolition Bill passed its second reading in the

42 "Liverpool", Liverpool Chronicle, 6 March 1805.

43 Liverpool Chronicle, 28 January 1807. 
House of Commons, they congratulated England "on this triumph of justice, humanity, and virtue". ${ }^{44}$

The Argus Letters and the two published responses they produced suggest that while abolitionism was on the rise in Liverpool, in 1805 abolitionists were still unwilling to take an open and public stand against the slave trade. The editor of the Liverpool Chronicle confirmed the increased presence of abolitionists in the town, although he intimated that Liverpool abolitionism, while large, was perhaps not quite as large as Argus had depicted. Moreover, Slang's warning to the editor and the editor's refusal to continue the debate indicate that the slaving faction still wielded considerable power in Liverpool. Ultimately, the fact that in 1805 there is no evidence of a Liverpool abolitionist committee, or an active abolitionist campaign suggests that either there was a lack of publicly known abolitionist-sympathisers, or, as for the Roscoe Circle, pressure still remained to be passive rather than active abolitionists.

\section{Abolition and Roscoe's parliamentary election in 1806}

When the freemen of Liverpool elected Roscoe to Parliament on 8 November 1806, it appeared to the country at large that Liverpool had finally turned its back on the slave trade. For the first time in the history of the movement, abolition formed an important issue in the general elections nationwide. Voters in several counties, including Yorkshire, Northampton, Durham and Cumberland forced candidates to declare in favour of abolition. Liverpool's other representative, the anti-abolitionist General Isaac Gascoyne later complained:

The attempts to make a popular clamour against the trade were never so conspicuous as during the last election, when the public newspapers had teemed with abuse of this trade, and when promises were required from different candidates that they would oppose its continuance. 45

At a post-election dinner, a candidate for Westminster who had also stood on a platform of abolition, in consolation for his defeat toasted the citizens of Liverpool for having elected "the celebrated Roscoe on whose banner was inscribed - "No Slave Trade"", ${ }^{46}$

\footnotetext{
${ }^{44}$ Liverpool Chronicle, 4 and 11 February 1807.

45 Drescher, “Whose Abolition?”, pp. 143-44, 148.

46 Ibid., p. 147.
} 
The abolition movement had increased momentum since its re-emergence in 1804. In September 1805, Pitt banned British slavers from trading to Guiana, and after his death in January 1806 Grenville's new coalition ministry, dominated by abolitionists, came to power. In May, following an abolitionist petition campaign, Parliament passed the Foreign Slave Trade Bill which forbid British subjects from participating in the slave trade to foreign and conquered islands. Promoted as a Bill to impede France's trade, it had much wider implications for abolition: it prohibited ships sailing under all flags from receiving repairs or being outfitted in British ports, and from being insured by British firms. Since many British ships sailed under the American flag, the Bill effectively ended two-thirds of the British slave trade. ${ }^{47}$

Surprisingly, the Liverpool candidates made conspicuously few references to the slave trade during the electoral campaign. Although Roscoe put forward his support for abolition, he did not portray himself as the abolitionist candidate, and did not let abolition dominate his campaign. In return, the camps of his staunchly pro-slave trade opponents, the incumbent MPs General Banastre Tarleton and Gascoyne, issued few warnings against the economic repercussions for Liverpool should Roscoe win. ${ }^{48}$ The limited discussion of abolition has caused historians to argue that, on the whole, the candidates' position for or against the slave trade did not decide the election in Liverpool as it had elsewhere in England.

That Roscoe counted slave traders among his supporters has further been used to demonstrate that the slave trade was a non-issue in the Liverpool election. Roscoe received substantial financial backing from several prominent slave-trading families, such as the Earles and Laces, as well as from his business partner Thomas Leyland. ${ }^{49}$ They may have believed that with the passage of the Foreign Slave Trade Bill abolition had become inevitable, and therefore backed Roscoe's promise to seek gradual abolition and full compensation for merchants' losses. ${ }^{50}$ Or they may have been confident that abolition would once again fail in Parliament. Indeed, Sanderson argues that the slaving faction remained active in promoting the slave trade's continuance, as six months earlier they had organised Liverpool's largest pro-slave trade petition, bearing more than a thousand signatures. He adds that abolition became a contentious issue for Roscoe supporters after the MP reached London and perceptibly allied with abolitionists,

\footnotetext{
47 Contemporaries believed that the Bill ended between a half and two-thirds of the British slave trade; Anstey suggests it was closer to three-quarters. Anstey, Slave Trade, pp. 364-76; Littlewood, The Roscoes, p. 218. 48 Wilson, Roscoe, pp. 140-41; Littlewood, The Roscoes, p. 219.

${ }^{49}$ Littlewood, The Roscoes, pp. 217, 220.

${ }^{50}$ Littlewood, The Roscoes, p. 220; Howman, “Abolitionism”, pp. 292-93; Sellers, “William Roscoe”, p. 58.
} 
causing Leyland to dissolve their partnership. ${ }^{51}$ Either way, historians attribute Roscoe's election to factors other than increased support for abolition in Liverpool.

Many historians have argued that Roscoe's electoral victory owed little to his political agenda, which included demanding the end of the East India Company's monopoly and the repeal of the Test and Corporation Acts. For instance, they highlight local party politics as a key factor to his success. Whilst Gascoyne, the Corporationendorsed Tory candidate who had represented Liverpool for ten years, was well respected in Liverpool, Tarleton, the anti-Corporation and Whig candidate, had alienated many of his supporters by repeatedly switching parties in the preceding years. Though Tarleton had represented Liverpool for sixteen years, the Whigs replaced him with Roscoe as their candidate. ${ }^{52}$ Gascoyne's supporters, meanwhile, disliked the violence displayed by Tarleton's followers, and split their votes between Gascoyne and Roscoe. ${ }^{53}$ In addition, historians note that Roscoe's well-attested bribery of the electorate stacked the odds in his favour. Roscoe admitted that his campaign expenditure rose to over $£ 12,000$, whereas Tarleton's and Gascoyne's had amounted to near $£, 4,000$ and $£ 3,000$ respectively. ${ }^{54}$ The incumbent MPs, feeling assured of their reelection, were likely caught off-guard by the suddenness of Roscoe's nomination, as well as the sums his campaign rapidly raised. Whereas they had announced their candidacies in mid-October, Roscoe issued his first public address on 31 October, and the election started the following day. When voting ended on 8 November, Roscoe headed the poll, followed closely by Gascoyne. ${ }^{55}$

Sanderson and Menzies argue that the election was fought exclusively along traditional party lines. ${ }^{56}$ The political dominance of the old Tory families had waned over the past decade, allowing the Whigs to gain a stronger foothold in local politics. At the same time, the Unitarian influence challenged the Established Church. Consequently, Roscoe, Currie and Rathbone had gained admittance to the Whigs, where they had helped to organise the party, despite their ineligibility to vote. ${ }^{57}$ By the time Roscoe vied for Parliament, Fladeland argues, his ongoing denunciation of the Corporation had won

51 Littlewood, The Roscoes, p. 220; Sanderson, "Liverpool Abolitionists", pp. 222, 224. Littlewood states that Leyland did not explain to Roscoe why he dissolved their partnership. Littlewood, The Roscoes, p. 227.

52 Roscoe, in fact, had been the Whigs' fifth choice of candidate, and did not immediately respond to their invitation to run. A. Wilson, Roscoe, p. 140.

53 Howman, "Abolitionism”, p. 291; Sanderson, "Liverpool Abolitionists", pp. 221-22.

54 Sanderson, "Liverpool Abolitionists", p. 223; Howman, “Abolitionism”, p. 291.

55 H. Roscoe, Life, p. 356. For a detailed account of the campaign see Littlewood, The Roscoes, pp. 216-25.

56 Sanderson, "Liverpool Abolitionists", p. 223; E. M. Menzies, "The Freeman Voter in Liverpool, 18021835", Transactions of the Historic Society of Lancashire and Cheshire, Vol.124, 1972, pp. 92-3.

${ }^{57}$ Fladeland, "Quartet", p. 38. 
him the respect of the working freemen, who constituted more than two-thirds of the 3,000 voters. ${ }^{58}$ Menzies explains that although declarations of policy remained still rare in this period, Roscoe "stood as a reformer and champion of the independence of the freemen". 59

Trepp and Wilson argue that personality rather than particular issues determined Roscoe's success. ${ }^{60}$ By 1806, having received public acclaim for his Life of Lorenzo and Life of Leo, Roscoe had reached the peak of his career. According to Wilson, the widespread recognition and status he obtained in the public arena for his literary talents, as well as for his contributions to Liverpool's developing cultural landscape, prevailed in the voters' estimation of him over his more unpopular political views. Or so his supporters hoped. They issued political pamphlets presenting Roscoe as a virtuous man and urged voters to view him as "a HUSBAND, a FATHER, a FRIEND, a COUNSELLOR." The pamphlets also reminded voters of Roscoe's great contributions to the town: the Athenaeum, the Lyceum, the Botanic Garden, and the School for the Blind. ${ }^{61}$ Roscoe's election, then, was about redefining Liverpool's cultural image as a "newly emergent enlightened town which sent an internationally known literary figure, poet, peace campaigner and abolitionist to London to do battle with "Old Corruption"', ${ }^{62}$

In short, historians argue that since concerns for the abolition of the slave trade did not significantly enter the 1806 parliamentary campaigns in Liverpool, Roscoe's election as MP does not indicate that opinions there had turned against the slave trade. Whilst the slave trade might not have been an important electoral issue, abolition must have factored in Roscoe's election. To suggest that Liverpool's appointment of a known abolitionist does not reflect a change in attitudes in the town is short-sighted. Take an example from Liverpool's history the previous decade. In 1792, workmen threatened to tear down certain marked houses should abolition pass. Henry Blundell, Mayor of Liverpool, even wrote to Prime Minister Pitt to request that extra troops be stationed nearby. ${ }^{63}$ Whether or not Blundell took the threat seriously or seized the opportunity to put further pressure on Pitt not to support abolition, the threat indicates the intensity of

\footnotetext{
${ }^{58}$ Fladeland, "Quartet”, p. 38; Sellers, "William Roscoe”, p. 57.

${ }^{59}$ E. M. Menzies, "Freeman Voter", pp. 92-3.

60 Trepp, “Liverpool Movement", p. 282.

61 A. Wilson, Roscoe, p. 141.

${ }^{62}$ Littlewood, The Roscoes, p. 220.

63 Blundell to Pitt, 14 Apr 1792, HO 42/20/69/f. 177, available at National Archives Website, http://www.nationalarchives.gov.uk, accessed 20 September 2012; Drescher, Capitalism and Antislavery, p. 211 n20; A. Wilson, Roscoe, p. 130.
} 
anti-abolitionist feeling in the town. But in 1806 Roscoe not only ran without any threats of such magnitude being made, but also won the election. While practical considerations may have predominated in the Whigs' support for Roscoe, his candidacy would have been unthinkable had anti-abolition feelings not considerably diminished over the last decade.

\section{Roscoe's violent homecoming}

Roscoe's time as MP for Liverpool was short-lived. Having left for London in November 1806, he returned home in May 1807 after the collapse of the government. Upon his arrival in Liverpool, a riot broke out when a mob of Tarleton supporters attacked Roscoe and his supporters. Historians have interpreted the primary motive for the altercation as discontent among Liverpool inhabitants, and particularly among local Guinea sailors, towards Roscoe's support of the Abolition Bill that was enacted by Parliament that May. They have seen in this altercation final proof that support for abolition had not significantly grown in Liverpool since the start of the campaign twenty years before. An examination of primary accounts of the conflict, however, reveals that resentment over abolition was not, in fact, a key cause for the discontent that manifested itself that day. Understanding the true reasons behind the fight, sheds new light on Roscoe's election and on Liverpool's relationship with the slave trade in 1806-1807.

Despite Roscoe's avoidance of the slave trade issue during his campaign, once in Parliament he saw it his duty to vocally support the cause. Prime Minister Lord Grenville introduced the Abolition Bill to the House of Lords on 2 January 1807. By 10 January it had passed its third reading in the Lords and was sent to the Commons. On 14 January, Roscoe informed Rathbone IV of his "resolution" to speak on the subject. He wrote that although he had an idea of what to say, he had not yet written it down, and worried that he might be "a weak and unworthy advocate of the great cause". ${ }^{4}$ On 23 February, at the second reading of the Bill in the Commons, Roscoe declared it his duty to his constituents to speak up on behalf of abolition. He continued, however, that he also had a duty to the members of his constituency engaged in the slave trade which demanded that he advocate that abolition be achieved through "gradual and proper measures". According to Littlewood, in trying to represent both sides of the debate

\footnotetext{
${ }^{64}$ Roscoe to Rathbone IV, 14 Feb 1807, LRO 920/ROS/5798.
} 
Roscoe left many individuals dissatisfied with his speech: he angered slave traders by voting for abolition, and annoyed abolitionists by overly praising slave traders. ${ }^{65}$

Historians have accused Roscoe of naïveté for believing that his constituents would support his vote for abolition. Both publicly and privately he affirmed that, never having made his abolitionism a secret, he would not now be reproved of for sticking to his beliefs. Writing to Rathbone IV shortly before his return to Liverpool he stated:

I do not augur much opposition from my conduct on the slave trade as my opinions on it were well known, \& I do not yet think so ill of the world as to supposed that [our] adherence to our own principles can be made a very substantial cause of reproach. ${ }^{66}$

The Abolition Bill passed its third reading in the Commons on 10 March, on $23^{\text {rd }}$ it was approved by the Lords, and on $25^{\text {th }}$ it received royal assent. No slaving vessels were to clear British ports after 1 May 1807, and none were allowed to land in the West Indies after the 1 March 1808. Parliament dissolved, and Roscoe rode back into Liverpool on the 2 May, the day after the Abolition Bill's enactment. There, an angry and violent crowd awaited him and his party.

On re-entering Liverpool, Roscoe was met by a party of his friends and supporters, who accompanied him through town to his bank, where he was to address the crowd. However, they were confronted en route by a mob. Henry Roscoe explained the altercation thus:

The part taken by [Roscoe] on the question of the slave trade, and the triumphant passing of the Bill for the abolition of that traffic, had excited a strong feeling against him amongst the lower classes in Liverpool. [...] Strong parties of seamen, chiefly consisting of the crew of vessels lately engaged in the African trade, armed with bludgeons and other weapons, were disposed along the street to obstruct the passage of the procession. ${ }^{67}$

In the ensuing struggle, horses were hit with sticks, and one, mounted by Roscoe's friend Captain Williams, was stabbed in the flank. A stone was thrown at Roscoe as he reached the bank, and Currie's son was pinned down. The assembly was forced to breakup. ${ }^{68}$

Although the younger Roscoe's description of the riot identifies abolition as its cause and Guinea sailors as its chief participants, other sources do not support his

${ }^{65}$ Littlewood, The Roscoes, pp. 231-32.

${ }^{66}$ Roscoe to Rathbone IV, 19 April 1807, LRO 920/ROS/5799; H. Roscoe, Life, p. 391; Trepp, "Liverpool Movement", p. 284; A. Wilson, Roscoe, p. 146; Sellers, "William Roscoe”, p. 60.

${ }^{67} \mathrm{H}$. Roscoe, Life, pp. 391-92. Henry Roscoe did not witness the events, as he was six at the time.

${ }^{68}$ H. Roscoe, Life, pp. 392-93; Elizabeth Greg, "Journal of Elizabeth Greg" in E. A. Rathbone, Records, pp. 289-91; A. Wilson, Roscoe, pp. 145-46. 
account. The description of the riot in the Liverpool Chronicle made no mention of seamen. The Liverpool Chronicle only reported that the rioters were distinguishable as Tarleton supporters by the green ribbons and roses they wore. ${ }^{69}$ The diary entry of seventeen-year-old Elizabeth Greg also indicates the rabble as Tarleton supporters, without mentioning sailors. ${ }^{70}$ A leaflet printed after the event by Roscoe's camp described their attackers as "Drunken men arrayed in green ribbands". ${ }^{71}$ Furthermore, on 20 May the Liverpool Chronicle republished articles on the Liverpool riot as reported by other newspapers, seven from London and three from Ireland. All ten articles indicate anti-Catholicism as the cause of the riot, with only two also blaming the town's slaving interests. ${ }^{72}$ None of the articles mentioned riotous seamen.

Most sources highlight Roscoe's support for Catholic emancipation as the leading cause for local discontent, with abolition as a lesser infraction. Roscoe's opponents published a satirical flyer, "A Copy of The Pope's Bull”, a purported endorsement of Roscoe by the Pope.

BE IT KNOWN TO ALL MEN BY THESE PRESENTS, that W. R. Esq. has done all that in him lay, to further the interests of the Holy Apostolic See, and to establish our supremacy, and that he hates the Protestant Ascendancy, which is very abominable in our sight, and under pretence of promoting Religious Freedom, he has endeavoured to overturn it, furthermore in his Holy Zeal has given his strenuous exertions to measures in our opinion the best calculated to set aside the Protestant Succession in Great Britain and Ireland [...] And the better to further their pious purposes, we desire all those, who may suffer from the loss of the Slave Trade, to be under no apprehensions about getting their living, as we will enable the said W. R. to work miracles, to supply them with daily bread, without the necessity of labouring. ${ }^{73}$

Roscoe's last act in Parliament was to speak out against the Test and Corporation Acts and in favour of Catholic emancipation, the issue that dissolved Grenville's ministry. ${ }^{74}$ Indeed, Pares argues that Whig MPs, such as Roscoe, overlooked the fact that popular opinion was overwhelmingly against Catholic emancipation. ${ }^{75}$ Roscoe himself indicated in a press release, published in the wake of his tumultuous homecoming, that his

\footnotetext{
${ }^{69}$ Liverpool Chronicle, 6 May 1807.

70 Greg, "Journal”, pp. 289-91.

71 "To the Independent Freemen of Liverpool", LRO 920/ROS/3884.

72 "Observations on Mr. Roscoe's Reception in Liverpool, May 2", Liverpool Chronicle, 20 May 1807. An eleventh article from an Irish newspaper focused entirely on Roscoe and not the riot.

73 “A copy of The Pope's Bull, Just Arrived in Liverpool”, LRO 920/ROS/3883.

${ }^{74}$ Fladeland, "Quartet", p. 41; H. Roscoe, Life, p. 391; Sanderson, "Liverpool Abolitionists", p. 226.

75 Richard Pares, King George III and the Politicians, London, 4th ed., 1963, p. 141.
} 
support of Catholic rights had primarily fuelled the unrest. He noted that only a few had rioted in response to his abolition vote. ${ }^{76}$

The fact that, on balance, Roscoe was not a successful politician has bearing on his reception. Wilson reveals that Roscoe disappointed his radical friends by not speaking up in the Commons. ${ }^{77}$ Henry Roscoe argued that the separation from his family and the dissolution of his partnership with Leyland placed a lot of strain on his father, who already had a difficult time adapting to public life. On 14 February 1807, Roscoe wrote to Rathbone V:

You cannot however readily conceive the difficulties that are to be got over in the House of Commons particularly in some minds, before a person can get the habit of expressing his sentiments in a way to do either himself or his cause any credit. I certainly, however, do not despair of attaining it, tho from the state of my health \& a consequent depression of spirits, I have hitherto been deterred almost wholly from the attempt. ${ }^{78}$

Roscoe was disorientated in London, and struggled to find the support he needed to gain confidence in his new environment. He quickly developed a depressive nervous disorder which made him question his competence as an MP. By February, his wife had joined him in London, and his anxiety subsided. ${ }^{79}$

Unfortunately, Henry Roscoe's description of his father's homecoming has directed historians' understanding of the event. Despite the Life's acknowledgment that anti-Catholicism contributed to Roscoe's unpopularity, time and again historians have seen in Roscoe's disastrous homecoming proof that Liverpudlians still overwhelmingly supported the slave trade despite his election. Granted, since Sanderson's work on the Liverpool Abolitionists in the 1970s, more historians have acknowledged the role Roscoe's support for Catholic emancipation played in turning Liverpudlians against Roscoe ${ }^{80}$ Howman, for one, is careful to specify that Roscoe angered his constituents by reneging on his promise to advocate for gradual abolition and compensation, rather than by his vote for abolition per se. Nonetheless, in persistently describing the crowd as comprised of angry seamen, or more specifically of unemployed Guinea seamen, each historian implies that abolition constituted the key cause for complaint. ${ }^{81}$

\footnotetext{
${ }^{76}$ H. Roscoe, Life, p. 397.

77 A. Wilson, Roscoe, p. 143-4.

78 Roscoe to Rathbone IV, 14 Feb 1807, LRO 920/ROS/5798.

${ }^{79}$ Littlewood, The Roscoes, pp. 227-29.

80 Sanderson, "Liverpool Abolitionists”, p. 226; Fladeland, “Quartet”, p. 41;

${ }^{81}$ Littlewood's recent biography of Roscoe is the exception to the rule. He does not mention seamen in his brief description of the riot, and remarks that Catholic Emancipation, more than abolition, caused the discontent. Littlewood, The Roscoes, p. 235.
} 
The Life of Roscoe has caused historians to incorrectly identify seamen as the main contributors to the riot. Trepp, Sellers and Sanderson solely rely on Roscoe's Life for an account of the event. They describe Roscoe's attackers as "seamen from slave vessels", "unemployed seamen" and even "half-starved seamen". ${ }^{22}$ As Sanderson has been the leading authority on Liverpudlian abolitionism over the last forty years, the error has been endlessly repeated. Even historians such as Fladeland and Wilson, who examined Elizabeth Greg's diary entry, have not questioned the presence of seamen at the riot. ${ }^{83}$ While this thesis does not seek to prove that Guinea sailors categorically did not participate in the riot, it is clear from the primary material that they were not the riot's defining feature or instigators.

Presenting seamen as avid slave trade supporters contributes to the misinterpretation of Liverpudlian attitudes towards the slave trade and its abolition. According to Clarkson, in 1787 Liverpool's Guinea seamen formed the town's largest anti-slave trade group, and were his most willing informants:

though no one else would come near me, to give me any information about the trade, these were always forward to speak to me, and to tell me their grievances, if it were only with the hope of being able to get redress. ${ }^{84}$

Abused seamen eagerly related their experiences to Clarkson, who boasted that in Liverpool he spoke to nearly all returning slave trade sailors. As many as three sailors a day would visit him at the King's Head pub. ${ }^{85}$ Christopher's work on slave ship sailors argues that, while some certainly abused slaves during the Middle Passage, their firsthand knowledge of enslavement pushed them to the vanguard of the political fight for abolition. They also worked with black shipmates - class more than race proved to be key. ${ }^{86}$ Moreover, Scott found evidence of extensive contact between sailors and slaves in the colonies, which West Indian laws tried to limit. Important to this thesis, he argues that in the 1790s, European sailors were responsible for reporting British antislavery discussions and legislative acts to colonial slaves. ${ }^{87}$

Roscoe's violent homecoming does not indicate, as many historians have asserted, that Liverpool's support of the slave trade remained close to the levels it had

82 Trepp, "Liverpool Movement", p. 284; Sanderson, "Liverpool Abolitionists", p. 226; Sellers, "William Roscoe", p. 60.

83 A. Wilson, Roscoe, p. 146; Fladeland, "Quartet”, p. 41.

84 Clarkson, History, Vol. I, p. 392.

85 Ibid., 393.

${ }^{86}$ Christopher, Captive Cargoes, pp. 14-8.

${ }^{87}$ Julius S. Scott III, "The Common Wind: Currents of Afro-American Communication in the Era of the Haitian Revolution”, Ph.D. Thesis, Duke University, Durham, 1986, pp. 64-8. 
been during the first half of the abolition campaign. It gives us no specific information on anti-abolitionism. All it tell is that a minority of the crowd harboured grievances against Roscoe's role in abolition, but that to the majority, his support for Catholic rights was much more unacceptable than his vote to end the slave trade. It suggests that attitudes had softened in Liverpool towards abolition, and that the abolition of the slave trade was no longer widely considered as disastrous to Liverpool's economy as it had been in the 1780s. Viewed in the context of descriptions of Liverpool abolitionism in The Picture of Liverpool and the Liverpool Chronicle, the discontent against Roscoe confirms that Liverpool had already started to turn its back on the slave trade prior to its abolition.

\section{Conclusion}

The little evidence that exists on the development of Liverpool abolitionism between 1796 and 1807 demonstrates that negative reactions to the slave trade, and positive views of abolition significantly increased in this decade. Taken individually, The Liverpool Guide, The Picture of Liverpool, the Argus letters, Roscoe's election and the accounts of his homecoming provide extremely limited evidence on attitudes towards the slave trade. But when viewed alongside each other, these otherwise problematic sources piece together a timeline of Liverpool's growing rejection of the slave trade. They show, as Drescher has argued, that the inhabitants of Liverpool were increasingly resentful of having the slave trade define them and their town, thus creating a cultural barrier between them and other Britons. And whilst for many rejection of the slave trade did not necessarily equate to endorsement of abolition, for others Liverpool's cultural development in the early nineteenth century meant that they could develop their moral opposition to the slave trade. The evidence suggests that the process, which had begun in the mid-1790s, had produced a sizeable abolitionist community by 1805 , although one still insecure in openly promoting its condemnation of the local slaving interest. Roscoe's election in late 1806 marked the start of abolitionism's social acceptability in Liverpool, as confirmed by the Liverpool Chronicle's endorsement of the cause from January 1807. 


\section{CONCLUSION}

In 1807 a new Liverpool guidebook entered the market. Unlike The Picture of Liverpool, which had recycled the structure and most of the content of Moss's Liverpool Guide, The Stranger in Liverpool, published by Thomas Kaye, was an entirely new guide. Starting with a history of the town, the guide traced Liverpool's ascendency in the slave trade, and acknowledged that the town owed "a great part of her present wealth" to the trade. ${ }^{88}$ The guide followed the history with a brief statement regretfully connecting the town's growth to a trade "so degrading to the national character, and so much at variance with sound policy, humanity and religion, as the African." It was "a page in our history", the guide continues, "upon which benevolence lets fall a tear of pity, and which, were it possible, it would expunge." The guide included Moss's old statistics, but this time followed the annual income from the sale of "slaves and souls of men" with two exclamation marks denoting the disbelief that such a traffic could ever have existed. The slave trade was now fully acknowledged as the shame of Liverpool. ${ }^{89}$

For twenty years Liverpool had stood apart in its support for the slave trade, but Liverpool's relationship to the slave trade had been atypical even before 1787. Most Britons had no immediate experience or understanding of the colonial slavery system or the slave trade, and historians have attributed widespread British apathy towards slavery before 1787 to Britain's physical distance from the slave societies of the West Indies. Slavery and the slave trade were, to a majority of Britons, out of sight and out of mind..$^{90}$ The same, however, cannot be said for the people of Liverpool. From the ships in the docks to the shackles on display in shop windows, the town teemed with reminders. Guinea sailors also returned with stories of the Middle Passage and the colonies. When the London Committee brought the horrors of the slave trade to popular attention in 1787, the British public responded vehemently against it, but Liverpudlians had lived with the terrible knowledge of the slave trade for decades and exhibited very few examples of antislave trade sentiment. Acceptance of the slave trade's necessity to Liverpool had become ingrained in local culture.

88 The Stranger in Liverpool; or, an Historical and Descriptive View of Liverpool and its Environs, Liverpool, 1807, pp. 18-20.

89 The Stranger in Liverpool, p. 26; Drescher, "Slaving Capital", p. 139.

90 Brown, Moral Capital, p. 51; Walvin, Zong, p. 178. 
Liverpudlians were not unanimous in their support of the slave trade, but even Liverpool abolitionism followed a distinctive pattern. To evaluate the success of the Roscoe Circle in 1787-1788 based on a comparison with the London Committee is unproductive. The Roscoe Circle never intended for their participation in the campaign to mirror the public stance taken by the London Abolitionists. As Liverpudlians they might have tried to specifically target their friends and neighbours, but the evidence suggests that they rarely did; their expectation was that outside pressures would prevail on the local slaving faction. In fact, as abolitionists in the capital of the slave trade they held a unique view of abolition: they had first hand experience of the wealth amassed by the trade and therefore understood the fears associated with abolition; they were friends and business partners with slave traders and knew some of them to be men of otherwise moral integrity; and they were bound together by a dissenting network in a town dominated and run by Anglicans, and prone to outbursts of violence.

Although the Roscoe Circle was ineffective locally in the short-term, it had some long-term positive outcomes for anti-slavery in Liverpool. Perhaps if Liverpool abolitionism had been grounded in the local Quaker community, and not in Roscoe's connection to the London Committee via his friendship with Barton, it might have endured beyond 1788 or reignited soon after 1804. The same might also have been true had Roscoe and Currie developed a friendly relationship with Clarkson. But the Roscoe Circle did eventually help to alter attitudes towards the slave trade by promoting the development of Liverpool polite culture. This is not to suggest that their involvement in establishing cultural institutions was a ploy to turn Liverpudlians against the trade, rather that growing support for abolition was a consequence of Liverpool's commitment to cultural development.

Despite the historical consensus saying otherwise, the evidence indicates that by May 1807 strong anti-abolitionist sentiment in Liverpool was minimal. The passage of the Foreign Slave Trade Act the year before had proved that Liverpool would not crumble without the slave trade, and when Roscoe returned to Liverpool his stance on Catholic rights, rather than his vote for abolition, was the focus of local discontent. In 1814, Liverpool produced its first abolitionist petition: with the help of the former slaving merchant John Gladstone, William Roscoe collected 30,000 signatures petitioning against the British sanctioned revival of the French slave trade. That the Roscoe Circle had an enduring impact on local anti-slavery is evidenced by the creation in Liverpool of England's first anti-slavery society in 1821. In 1823, the society's founder, the Liverpool 
Quaker merchant James Cropper, a Roscoe Circle member and leading British abolitionist, invited Roscoe to take on the society's presidency. ${ }^{91}$

${ }^{91}$ Drescher, "Slaving Capital", pp. 139-40; A. Wilson, Roscoe, p. 152. The French slave trade, in abeyance after the French Republic abolished slavery in 1794, re-emerged in 1814-15 and was not made illegal until 1848. See Paul Michael Kielstra, The Politics of Slave Trade Suppression in Britain and France, 1814-48: Diplomacy, Morality, and Economics, Basingstoke, 2000. 


\title{
BIBLIOGRAPHY
}

\section{PRIMARY SOURCES}

\author{
Manuscripts: \\ British Library \\ London Abolition Committee Minutes 1787-1788, Add MS 21254, \\ accessible at Slavery, Abolition and Social Justice website, www.slavery.amdigital.co.uk \\ Liverpool Record Office \\ Currie Papers Currie-Moore correspondence, 1788, 920/CUR/106-108. \\ Roscoe Papers Barton-Roscoe correspondence, 1787-1788, 920/ROS/239-257. \\ Miscellaneous political pamphlets, 920/ROS/3883-3884.
}

National Archives

Home Office Domestic Correspondence Blundell to Pitt, 1792, HO 42/20/69, ff 177-185, accessible at National Archives website, www.nationalarchives.gov.uk.

Published Materials:

\section{Books, Pamphlets and Poetry}

Benezet, Anthony, A Caution and a Warning to Great Britain and her Colonies, Philadelphia, 1767.

Clarkson, Thomas, An Essay on the Impolicy of the African Slave Trade, London, 1788.

-- , The History of the Rise, Progress, and Accomplishment of the Abolition of the African Slave Trade by the British Parliament, 2 vols., London 1808.

-- , The Substance of the Evidence of Sundry Persons on the Slave Trade, London, 1789, in John Oldfield (ed.), The British Transatlantic Slave Trade, Vol.3, London, 2003.

Greg, Elizabeth, 'Journal of Elizabeth Greg' in E. A. Rathbone, Records of the Rathbone Family, Edinburgh, 1913, pp. 284-312.

Harris, Raymond, Scriptural Researches on the Licitness of the Slave Trade, Shewing its Conformity with the Principles of Natural and Revealed Religion, Delineated in the Sacred Writings of the Word of God, London, 1788.

The London Encyclopaedia, or Universal Dictionary of Science, Art, Literature, and Practical Mechanics, Comprising a Popular View of the Present State of Knowledge. Illustrated by Numerous Engravings, a General Atlas, and Appropriate Diagrams, Volume 7, London, 1829. 
Roscoe, William, A General View of the African Slave Trade, Demonstrating its Injustice and Impolicy; with Hints Towards a Bill for its Abolition, London, 1788.

-- , Mount Pleasant, Warrington, 1777.

-- , A Scriptural Refutation of a Pamphlet lately published by the Rev. Raymond Harris entitled, "Scriptural Researches on the Licitness of the Slave Trade", in Four Letters from the Author to a Friend, London, 1788.

-- , The Wrongs of Africa, Part the First, London, 1787.

Rushton, Edward, Poems, London, 1806.

-- , 'West Indian Eclogues', reprinted in Alan Richardson (ed.), Verse: Volume IV, Peter J. Kitson and Debbie Lee (eds.), Slavery, Abolition and Emancipation: Writings in the British Romantic Period (8 vols.), pp.31-50.

Walker, John, A Descriptive Poem on the Town and Trade of Liverpool, Liverpool, 1789;

\section{Directories}

John Gore, Gore's Liverpool Directory, Liverpool, 1796.

--, Gore's Liverpool Directory, Liverpool, 1781.

--, Gore's General Directory, Liverpool, 1800.

--, Gore's General Directory, Liverpool, 1803.

--, Gore's General Directory, Liverpool, 1805.

--, Gore's General Directory, Liverpool, 1807.

The Universal British Directory of Trade, Commerce, and Manufacture, London, 1794.

Woodward's New Liverpool Directory, Liverpool, 1804.

\section{Guidebooks}

William Moss, The Liverpool Guide, $1^{\text {st }}$ ed., Liverpool, 1796.

William Moss, The Liverpool Guide, $2^{\text {nd }}$ ed., Liverpool 1797.

William Moss, The Liverpool Guide, $3^{\text {rd }}$ ed., Liverpool 1799.

William Moss, The Liverpool Guide, $4^{\text {th }}$ ed., Liverpool 1801.

Anon., The Picture of Liverpool; or Stranger's Guide, Liverpool, 1805.

Anon., The Stranger in Liverpool; or, an Historical and Descriptive View of Liverpool and its Environs, Liverpool, 1807.

\section{Periodicals}

Liverpool Chronicle, 1804-1807.

Monthly Repository, 'Obituary. Rev. John Yates', vol. 22, 1827, pp. 66-70.

The Times, 22 November 1787. 


\section{Patliamentaty Papers}

Accounts and Papers

A\&P, 1789, XXIV. Minutes of the Evidence taken before a Committee of the Whole House on Regulation of the Slave Trade.

A\&P, 1789, XXV. Minutes of the Evidence taken before a Committee of the Whole House to consider the Slave Trade.

$A \& P, 1789$, XXVI. Report of the Privy Council Committee on the Slave Trade.

$A \& P, 1790$, XXIX. Minutes of the Evidence: Select Committee on the Slave Trade.

$A \& P, 1790$, XXX. Minutes of the Evidence: Select Committee on the Slave Trade.

$A \circledast P, 1791$, XXXIV. Minutes of the Evidence: Select Committee on the Slave Trade.

Act of Parliament

'An Act to Regulate the Carrying of Slaves, 1788' in Elizabeth Donnan (Ed.), Documents Illustrative of the History of the Slave Trade to America: Volume II: The Eighteenth Century, Buffalo, 2002, pp. 582-589.

\section{Websites}

Barton Family History website, bartonhistory.wikispaces.com.

The Trans-Atlantic Slave Trade Database, www.slavevoyages.org.

\section{SECONDARY SOURCES}

\section{Theses:}

Behrendt, Stephen D., "The British Slave Trade, 1785-1807: Volume, Profitability, and Mortality", Ph.D. Thesis, University of Wisconsin, Madison, 1993.

Howan, Brian, "An Analysis of Slave Abolitionists in the North West of England", Ph.D. Thesis, University of Warwick, 2006.

Scott, Julius S., 'The Common Wind: Currents of Afro-American Communication in the Era of the Haitian Revolution', Ph.D. Thesis, Duke University, Durham, 1986.

\section{Website:}

The $18^{\text {th }}$ Century Liverpool Quakers", www.liverpoolquakers.org.uk/about/liverpool-and-thequakers, accessed 4 December 2012. 


\section{Publications:}

Anstey, Roger, The Atlantic Slave Trade and British Abolition 1760-1810, London, 1975.

Baines, Thomas, History of the Commerce and Town of Liverpool, London, 1852.

Barker, Hannah, Newspapers, Politics, and English Society 1695-1855, Harlow, 2000.

Behrendt, Stephen D., "Human Capital in the British Slave Trade", in David Richardson, Suzanne Schwarz and Anthony Tibbles, eds., Liverpool and Transatlantic Slavery, Liverpool, 2007, pp. 66-97.

Bennett, Robert J., The Voice of Liverpool Business: The First Chamber of Commerce and the Atlantic Economy, 1774-c.1796, Liverpool, 2010.

Bradley, James E., Religion, Revolution and English Radicalism, Cambridge, 1990.

Brazendale, David, Georgian Liverpool: A Guide to the Town in 1797, Lancaster, 2007.

Brown, Christopher Leslie, Moral Capital: Foundations of British Abolitionism, Chapel Hill, 2006.

Cameron, Gail, and Stan Crook, Liverpool: Capital of the Slave Trade, Liverpool, 1992.

Christopher, Emma, Slave Ship Sailors and their Captive Cargoes, 1730-1807, New York, 2006.

Currie, William Wallace, Memoir of the Life, Writings, and Correspondence of James Currie, M.D. F.R.S. of Liverpool, Vol. I, London, 1831.

Curtin, Philip D., The Atlantic Slave Trade: A Census, Madison, 1969.

Davis, D. B., The Problem of Slavery in the Age of Revolution, 1770-1823, Ithaca, 1975.

Dellarosa, Franca, "Questioning "the Enterprising Spirit of the People": Abolitionist Poetry in Liverpool, 1784-1788”, La Questione Romantica, vol.18/2005, 2008, pp. 17-32.

Dorigny, Marcel "Mirabeau and the Société des Amis des Noirs: Which Way to Abolish Slavery?," Marcel Dorigny (ed.), The Abolitions of Slavery, Paris, 2003, pp. 121-32.

Drescher, Seymour, Capitalism and Antislavery, in Stephen Farrell, Melanie Unwin and James Walvin (eds.), The British Slave Trade: Abolition, Parliament and People, Edinburgh, 2007, pp. 4265.

-- , Econocide: British Slavery in the Era of Abolition, Pittsburgh, 1977.

-- , 'Public Opinion and Parliament in the Abolition of the British Slave Trade', Parliamentary History, Volume 26 Supplement, 2007, pp. 42-65

-- , "The Shocking Birth of British Abolitionism", Slavery and Abolition, Vol. 33, No. 4, Dec. 2012, pp. 571-93. 
-- , "The Slaving Capital of the World: Liverpool and National opinion in the Age of Abolition", Slavery and Abolition, 9:2, 1988, pp.128-43.

Dresser, Madge, Slavery Obscured: The Social History of the Slave Trade in an English Provincial Port, London, 2001.

Fladeland, Betty, "A Quartet of Liverpudlians: William Rathbone, William Roscoe, James Currie and Edward Rushton", Abolitionists and Working-Class: Problems in the Age of Industrialization, London, 1984.

Hertzog, Keith P., "Naval Operations in West Africa and the Disruption of the Slave Trade during the American Revolution", American Neptune, Vol. 55, No. 1, 1995, pp. 42-8.

Hochschild, Adam, Bury the Chains: Prophets and Rebels in the Fight to Free an Empire's Slaves, Boston, 2005.

Howley, Frank, Slavers, Traders and Privateers: Liverpool, the African Trade and Revolution, 1773-1808, Birkenhead, 2008.

Howman, Brian, "Abolitionism in Liverpool", in David Richardson, Suzanne Schwarz and Anthony Tibbles (eds.), Liverpool and Transatlantic Slavery, Liverpool, 2007, pp. 277-96.

Huddleston, Jonathan, And Children's Teeth Are Set On Edge: Adam Hodgson and the Razing of Caton Chapel, self-published e-book, $2^{\text {nd }}$ ed., 2011, accessible at http://www.tioli.co.uk, accessed May 2013.

Jennings, Judith, The Business of Abolishing the Slave Trade, 1783-1807, London, 1997.

Kielstra, Paul Michael, The Politics of Slave Trade Suppression in Britain and France, 1814-48: Diplomacy, Morality, and Economics, Basingstoke, 2000.

Krawczyk, Scott, "Mediating Abolition: The Collaborative Consciousness of Liverpool's William Roscoe and James Currie", Journal for Eighteenth-Century Studies, Vol. 34, No. 2, 2011, pp. 20927.

Littlewood, Kevin, The Roscoes of Liverpool. Volume 1: Love, Fame and Family Misfortunes, 1753-1816, self-published e-book, Southport, 2011.

Liverpool and Slavery: An Historical Account of the Liverpool-African Slave Trade by a Genuine "Dicky Sam”, Liverpool, 1884.

LoGerfo, James W., "Sir William Dolben and "The Cause of Humanity": The Passage of the Slave Trade Regulation Act of 1788”, Eighteenth-Century Studies, Vol. 6, No. 4, Summer, 1973, pp. 431-51.

Longmore, Jane, "Cemented by the Blood of a Negro'? The Impact of the Slave Trade on Eighteenth Century Liverpool", in David Richardson, Suzanne Schwarz and Anthony Tibbles (eds.), Liverpool and Transatlantic Slavery, Liverpool, 2007, pp. 227-51. 
-- , “Civic Liverpool: 1680-1800", in John Belchem (ed.), Liverpool 800: Culture, Character and History, Liverpool, 2006, pp. 113-70.

Macnaughton, Donald A., "Roscoe, William (1753-1831)", Oxford Dictionary of National Biography, Oxford University Press,2004 [http://www.oxforddnb.com/view/article/24084, accessed 1 June 2013].

Menzies, E. M., "The Freeman Voter in Liverpool, 1802-1835", Transactions of the Historic Society of Lancashire and Cheshire, Vol.124, 1972, pp. 85-107.

Morgan, Kenneth, "Liverpool's Dominance in the British Slave Trade, 1740-1807”, in David Richardson, Suzanne Schwarz and Anthony Tibbles (eds.), Liverpool and Transatlantic Slavery, Liverpool, 2007, pp. 14-42.

Muir, Ramsay, A History of Liverpool, London, 1907.

Oldfield, J. R., Popular Politics and British Anti-Slavery: The Mobilisation of Public Opinion Against the Slave Trade, 1787-1807, London, 1998.

-- , "The London Committee and Mobilization of Public Opinion against the Slave Trade", Historical Journal, Vol. 35, No. 2, June 1992, pp. 331-43.

Pares, Richard, King George III and the Politicians, $4^{\text {th }}$ ed., London, 1963.

Pope, David, "The Wealth and Social Aspirations of Liverpool's Slave Merchants of the Second Half of the Eighteenth Century", in D. Richardson, S. Schwarz and A. Tibbles, Liverpool and Transatlantic Slavery, Liverpool, 2007, pp. 164-226.

Porter, Dale H., The Abolition of the Slave trade in England, 1784-1807, Hamden, 1970.

Rathbone, E. A., Records of the Rathbone Family, Edinburgh, 1913.

Rawley, James A, London, Metropolis of the Slave Trade, Columbia, 2003.

-- , with Stephen D. Behrendt, The Transatlantic Slave Trade: A History, Revised Edition, Lincoln, 2005.

Rediker, Marcus, Between the Devil and the Deep Blue Sea, Cambridge, 1987.

-- , The Slave Ship: A Human History, London, 2007

Richardson, Alan, "Introduction", in Peter J. Kitson and Debbie Lee (eds.), Slavery, Abolition and Emancipation: Writings in the British Romantic Period (8 vols.), Alan Richardson (ed.), Literary Forms: Verse, (Vol. 4), London, 1999, pp. ix-xxvi.

Richardson, David, 'The Ending of the British Slave Trade in 1807: The Economic Context,' in Stephen Farrell, Melanie Unwin and James Walvin (eds.), The British Slave Trade: Abolition, Parliament and People, Edinburgh, 2007, pp. 127-40.

Roscoe, Henry, The Life of William Roscoe, Vol. I, London, 1833. 
Royden, Michael, "Rushton, Edward (1756-1814)", Oxford Dictionary of National Biography, Oxford University Press, 2004. [http://www.oxforddnb.com/view/article/24286, accessed 22 March 2013].

Sanderson, F. E., "The Liverpool Abolitionists", in R. Anstey and P. E. H. Hair (eds.), Liverpool, the African Slave Trade, and Abolition, Chippenham, 1989, pp.196-238.

-- , "The Liverpool Delegates and Sir William Dolben's Bill”, Transactions of the Historic Society of Lancashire and Cheshire, Vol.124, 1972, pp. 57-83.

-- , "Liverpool and the Slave Trade: A Guide to Sources", Transactions of the Historic Society of Lancashire and Cheshire, Vol. 124, 1972, pp. 154-76.

-- , “The Structure of Politics in Liverpool, 1780-1807”, Transactions of the Historic Society of Lancashire and Cheshire, Vol. 127, 1977, pp. 65-89.

Sellers, Ian, "William Roscoe, the Roscoe Circle and Radical Politics in Liverpool, 1787-1807", Transactions of the Historic Society of Lancashire and Cheshire, Vol. 120, 1968, pp. 45-62.

Shepherd, William, "Life of Edward Rushton", in Edward Rushton, Poems and Other Writings By the Late Edward Rushton, London, 1824.

Smithers, Henry, Liverpool, Its Commerce, Statistics and Institutions, Liverpool, 1825.

Stobart, Jon, "Culture versus commerce: societies and spaces for elites in eighteenth-century Liverpool”, Journal of Historical Geography, vol. 28, no. 4, 2002, pp. 471-85.

Sutton, Ian, "Roscoe circle (act. 1760s-1830s)", Oxford Dictionary of National Biography, Oxford University Press. [http://www.oxforddnb.com/view/theme/101301, accessed 19 May 2013].

Swaminathan, Srividhya, "Reporting Atrocities: A Comparison of the Zong and the Trial of Captain John Kimber", Slavery and Abolition, Vol. 31, No. 4, Dec. 2010, pp. 483-99.

Sweet Rosemary, The Writings of Urban Histories in Eighteenth-century England, Oxford, 1997.

Touzeau, James, The Rise and Progress of Liverpool from 1551 to 1835, Liverpool, 1910.

Trepp, Jean, "The Liverpool Movement for the Abolition of the English Slave Trade", Journal of Negro History, Vol.13, No.3, July 1928, pp.265-85.

Troughton, Thomas, The History of Liverpool from the Earliest Authenticated Period, Liverpool, 1810.

Wallace, James, A General and Descriptive History of the Ancient and Present State of the Town of Liverpool, Liverpool, 1795.

Walvin, James, The Quakers: Money and Morals, London, 1998.

--, The Zong: A Massacre, the Law and the End of Slavery, New Haven, 2011. 
Williams, Gomer, History of the Liverpool Privateers and Letters of Marque, with an Account of the Liverpool Slave Trade, 1744-1812, London and Liverpool, 1897, Liverpool and Quebec, 2004.

Wilson, Arline, William Roscoe: Commerce and Culture, Liverpool, 2008.

Wood, Marcus, "Packaging Liberty and Marketing the Gift of Freedom", in Stephen Farrell, Melanie Unwin and James Walvin (eds.), The British Slave Trade: Abolition, Parliament and People, Edinburgh, 2007, pp. 203-24. 